\title{
Estimated Water Use and Availability in the Pawtuxet and Quinebaug River Basins, Rhode Island, 1995-99
}

By Emily C. Wild and Mark T. Nimiroski

Prepared in cooperation with the Rhode Island Water Resources Board

Scientific Investigations Report 2006-5154 


\title{
U.S. Department of the Interior DIRK KEMPTHORNE, Secretary
}

\author{
U.S. Geological Survey \\ P. Patrick Leahy, Acting Director
}

\section{U.S. Geological Survey, Reston, Virginia: 2007}

For product and ordering information:

World Wide Web: http://www.usgs.gov/pubprod

Telephone: 1-888-ASK-USGS

For more information on the USGS - the Federal source for science about the Earth, its natural and living resources, natural hazards, and the environment:

World Wide Web: http://www.usgs.gov

Telephone: 1-888-ASK-USGS

Any use of trade, product, or firm names is for descriptive purposes only and does not imply endorsement by the U.S. Government.

Although this report is in the public domain, permission must be secured from the individual copyright owners to reproduce any copyrighted materials contained within this report.

Suggested citation:

Wild, E.C., and Nimiroski, M.T., 2007, Estimated water use and availability in the Pawtuxet and Quinebaug River Basins, Rhode Island, 1995-99: U.S. Geological Survey Scientific Investigations Report 2006-5154, 68 p. 


\section{Contents}

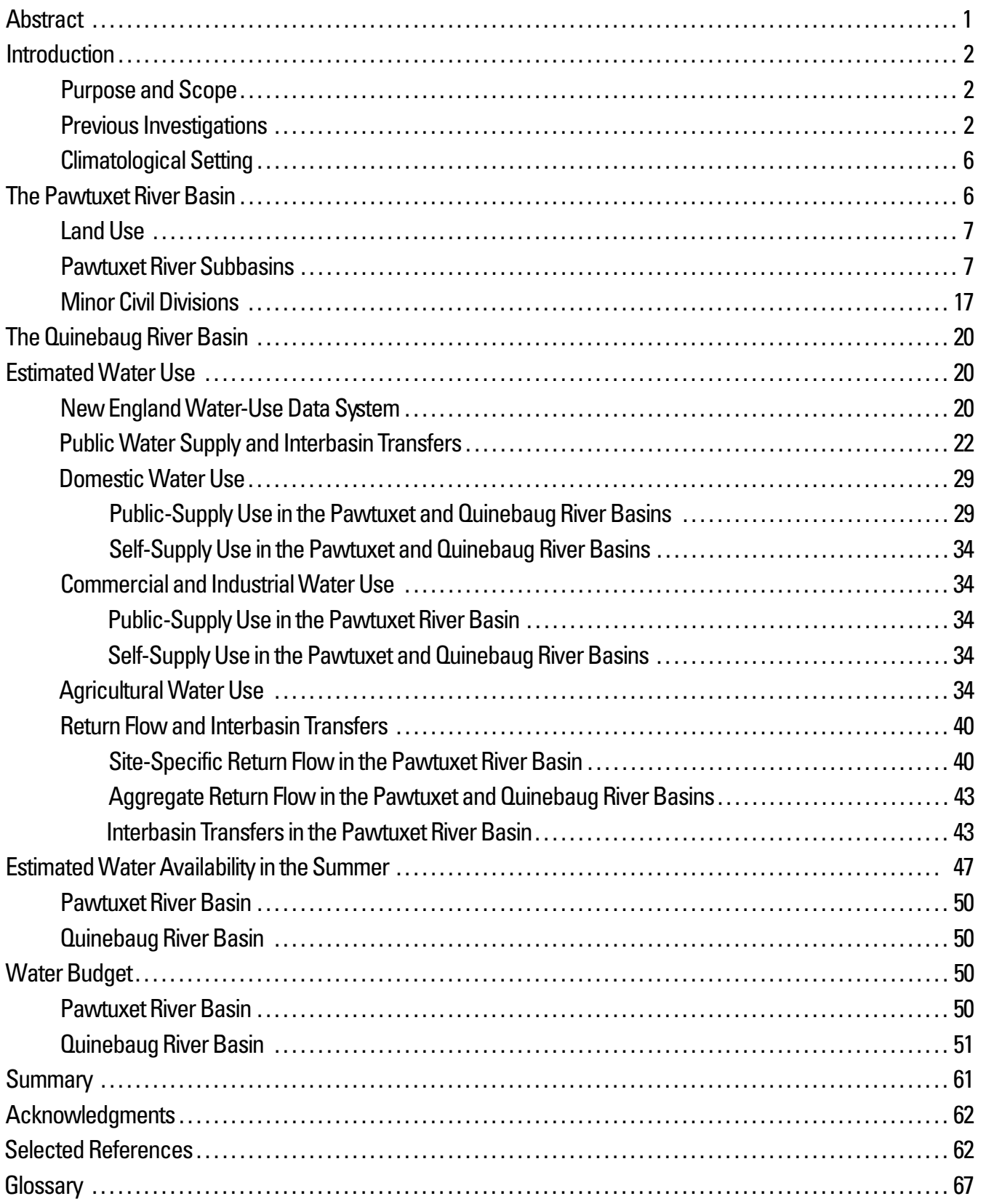




\section{Figures}

1. Map showing towns and climatological stations in the Pawtuxet River Basin, central

Rhode Island, and Quinebaug River Basin, western Rhode Island

2-3. Diagrams showing:

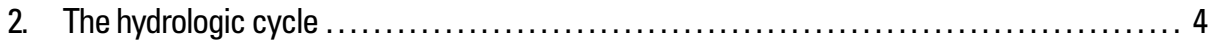

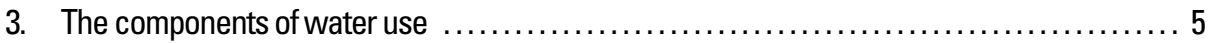

4-10. Maps showing:

4. Subbasins in the Pawtuxet and Quinebaug River Basins .9

5. Aquifers and selected production wells for the subbasins in the Pawtuxet and Quinebaug

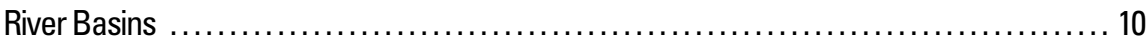

6. The 8-, 10-, and 12-digit Watershed Boundary Dataset delineations for the Pawtuxet and

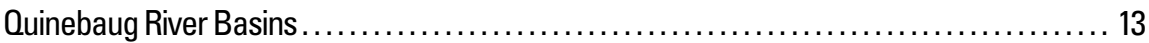

7. Scituate Reservoir Complex subbasin with selected partial-record stream-gaging stations and surficial deposits, Pawtuxet River Basin................................... 15

8. Stream-gaging stations, Rhode Island Pollutant Discharge Elimination System sites, and wastewater-treatment plants associated with the Pawtuxet and Quinebaug River Basins . . 16

9. The Quinebaug River Basin in western Rhode Island, northeastern Connecticut, and south-central Massachusetts ............................................. 21

10. Public water-supply districts associated with the Pawtuxet River Basin and in the northern

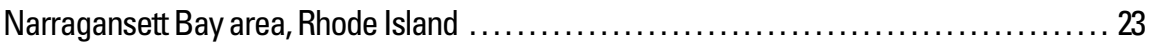

11-16. Diagrams showing:

11. Johnston Water District interconnections, purchases, distribution, exports, and estimated water uses in the Pawtuxet River Basin, 1995-99

12. Kent County Water Authority withdrawals, interconnections, purchases, distribution, exports, and estimated water uses, central Rhode Island, 1995-99

13. Providence Water Supply Board $A$, withdrawals, interconnections, distribution, and estimated water uses, central Rhode Island; and $B$, retail distribution, exports, and estimated water uses, 1995-99

14. Warwick Water Department interconnections, purchases, distribution, exports, and estimated water uses, central Rhode Island, 1995-99.

15. Public-supply withdrawals and estimated exports from the Pawtuxet River Basin, 1995-99

16. Estimated public wastewater collection, discharge, and estimated exports from the Pawtuxet River Basin, 1995-99

17-18. Graphs showing:

17. Estimated water availability for June, July, August, and September from sand and gravel deposits for the subbasins in the Pawtuxet and Quinebaug River Basins for the $A$, 50th percentile; $B$, 50th percentile for the 7-day, 10-year low-flow scenario; and $C$, 50th percentile for the Aquatic Base Flow scenario . . . . . 54

18. Estimated water availability for June, July, August, and September from till deposits for the subbasins in the Pawtuxet and Quinebaug River Basins for the

$A$, 50th percentile; $B$, 50th percentile for the 7-day, 10 -year low-flow scenario; and $C$, 50 th percentile for the Aquatic Base Flow scenario

19. Maps showing the water withdrawal-to-availability ratios in $A$, June; $B$, July; $C$, August; and $D$, September for the subbasins in the Pawtuxet and Quinebaug River Basins at the 50th percentile for the 7-day, 10-year low-flow scenario 


\section{Tables}

1. Summary of National Oceanic and Atmospheric Administration climatological stations and data pertinent to the Pawtuxet River Basin, central Rhode Island, and to the Quinebaug River Basin, western Rhode Island, 1995-99

2. Total town populations by subbasin for 1990, estimated populations for 1995-99, and estimated populations on public and self-supply and on public and self-disposal in the Pawtuxet and Quinebaug River Basins, 1995-99 . ...

\section{8}

3. Town land area and land-use area by category in the subbasins of the Pawtuxet and Quinebaug River Basins, 1995-99. 11

4. Land-use area and percentage of land-use area by major public water-supply district for the subbasins in the Pawtuxet River Basin study area and areas outside of the Pawtuxet River Basin, 1995-99

5. Defined subbasins in the Pawtuxet and Quinebaug River Basin study areas compared to the 10-digit and 12-digit Natural Resources Conservation Service Watershed Boundary Dataset (2003).

6. Summary of total town land area, land area in the Pawtuxet and Quinebaug River Basins, total 1990 town populations and estimated 1995-99 populations, and land-use area by category in the Pawtuxet and Quinebaug River Basins .......................... 18

7. Withdrawals by major public water-supply districts in and outside the subbasins of

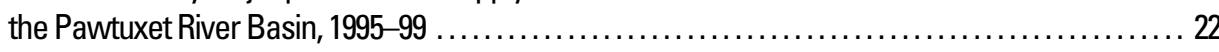

8. Minor public water suppliers by subbasin in the Pawtuxet and Quinebaug River Basins, 1995-99

9. Ground-water and surface-water withdrawals by town and subbasin in the Pawtuxet and Quinebaug River Basins, 1995-99

10. Average withdrawals and purchases for the Kent County Water Authority for June, July, August, and September, 1995-99

11. Withdrawals, discharges, retail sales, and wholesale purchases for the Providence Water Supply Board system in June, July, August, and September, 1995-99.................... 32

12. Estimated water use by town and subbasin in the Pawtuxet and Quinebaug River Basins, $1995-99$

13. Estimated consumptive water use by town and subbasin in the Pawtuxet and Quinebaug River Basins, 1995-99.

14. Estimated water use for each 2-digit Standard Industrial Classification code by town in the Pawtuxet and Quinebaug River Basins, 1995-99.

15. Estimated public- and self-disposed domestic, commercial, industrial, and metered return flow by subbasin in the Pawtuxet and Quinebaug River Basins, 1995-99 ..................... 41

16. Return flows by subbasin for the Rhode Island Pollutant Discharge Elimination System sites

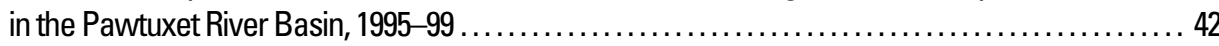

17. Return flow from wastewater-treatment facilities within and outside of the Pawtuxet River Basin, 1995-99

18. Summary of estimated water withdrawals, imports, exports, use, consumptive use, and return flow in the Pawtuxet River Basin, 1995-99 . . ................................ 45

19. Summary of estimated water withdrawals, imports, exports, use, consumptive use, and return flow in the Quinebaug River Basin, 1995-99.....

2. U.S. Geological Survey stream-gaging stations and minimum streamflows used in the analysis of water availability in the Pawtuxet and Quinebaug River Basins, $1995-99 \ldots \ldots \ldots \ldots \ldots \ldots \ldots 48$

21. Summer gross yields for the index stream-gaging stations used in the water-availability analysis in the Pawtuxet and Quinebaug River Basins . ... 
22. Estimated gross yields; gross yields minus the 7-day, 10-year low flow; and gross yields minus the Aquatic Base Flow per unit area for the two index stations used to determine water availability for June, July, August, and September in the Pawtuxet and Quinebaug River Basins

23. Estimated ground-water availability and total availability for June, July, August, and September in the Pawtuxet River Basin, 1995-99

24. Average water withdrawals for June, July, August, and September in the subbasins of the Pawtuxet River Basin, 1995-99

25. Summary of water withdrawal-to-availability ratios for June, July, August, and September in the Pawtuxet River Basin, 1995-99

26. Estimated gross yield; gross yield for the 7-day, 10-year low-flow scenario; and gross yield for the Aquatic Base Flow scenario for June, July, August, and September in the Quinebaug River Basin.

27. Average water withdrawals for June, July, August, and September in the towns in the Quinebaug River Basin, 1995-99.

28. Summary of water withdrawal-to-availability ratios for June, July, August, and September in the Quinebaug River Basin, 1995-99....

29. Average water budget by subbasin for the Pawtuxet River Basin ....................... 60

30. Average water budget for the Quinebaug River Basin

\section{Conversion Factors, Vertical Datum, Abbreviations, and Acronyms}

\begin{tabular}{lcl}
\hline Multiply & By & To obtain \\
\hline acre & 4,047 & square meter $\left(\mathrm{m}^{2}\right)$ \\
acre & 0.4047 & hectare $(\mathrm{ha})$ \\
foot $(\mathrm{ft})$ & 0.3048 & meter $(\mathrm{m})$ \\
square foot $\left(\mathrm{ft}^{2}\right)$ & 0.09290 & square meter $\left(\mathrm{m}^{2}\right)$ \\
square foot per day $\left(\mathrm{ft}^{2} / \mathrm{d}\right)$ & 0.09290 & square meter per day $\left(\mathrm{m}^{2} / \mathrm{d}\right)$ \\
gallons per day $(\mathrm{gal} / \mathrm{d})$ & 0.003785 & cubic meter per day $\left(\mathrm{m}^{3} / \mathrm{d}\right)$ \\
mile $(\mathrm{mi})$ & 1.609 & kilometer $(\mathrm{km})$ \\
million gallons per day $(\mathrm{Mgal} / \mathrm{d})$ & 3,785 & cubic meters per day $\left(\mathrm{m}^{3} / \mathrm{d}\right)$ \\
million gallons per day per square mile & $1,462.1$ & cubic meter per day per square kilometer \\
$\quad\left(\mathrm{Mgal} / \mathrm{d} / \mathrm{mi}^{2}\right)$ & & $\left(\mathrm{m}^{3} / \mathrm{d} / \mathrm{km}^{2}\right)$ \\
square mile $\left(\mathrm{mi}^{2}\right)$ & 2.590 & square $\mathrm{kilometer}\left(\mathrm{km}^{2}\right)$ \\
\hline
\end{tabular}

Temperature is given in degrees Fahrenheit $\left({ }^{\circ} \mathrm{F}\right)$, which can be converted to degrees Celsius $\left({ }^{\circ} \mathrm{C}\right)$ by the following equation:

${ }^{\circ} \mathrm{C}=\left({ }^{\circ} \mathrm{F}-32\right) / 1.8$

Vertical coordinate information is referenced to the North American Vertical Datum of 1988 (NAVD88).

Horizontal coordinate information is referenced to the North American Datum of 1983 (NAD83).

To convert water use and availability data to cubic feet per second, multiply million gallons per day by 1.5466 . 


\section{Abbreviations and Acronyms}

$\begin{array}{ll}\text { 7010 } & \text { 7-day, 10-year low flow } \\ \text { ABF } & \text { Aquatic Base Flow } \\ \text { GIS } & \text { Geographic Information Systems } \\ \text { HUC } & \text { Hydrologic Unit Code } \\ \text { IWR-MAIN } & \text { Institute of Water Resources, Municipal and Industrial Needs System } \\ \text { KCWA } & \text { Kent County Water Authority } \\ \text { MCD } & \text { Minor Civil Division } \\ \text { NCDC } & \text { National Climatic Data Center } \\ \text { NEWUDS } & \text { New England Water-Use Data System } \\ \text { NHD } & \text { National Hydrography Dataset } \\ \text { NOAA } & \text { National Oceanic and Atmospheric Administration } \\ \text { NRCS } & \text { Natural Resources Conservation Service } \\ \text { ProvWater } & \text { Providence Water Supply Board } \\ \text { RIDEM } & \text { Rhode Island Department of Environmental Management } \\ \text { RIEDC } & \text { Rhode Island Economic Development Corporation } \\ \text { RIGIS } & \text { Rhode Island Geographic Information System } \\ \text { RIPDES } & \text { Rhode Island Pollutant Discharge Elimination System } \\ \text { SCS } & \text { Soil Conservation Service } \\ \text { SIC } & \text { Standard Industrial Classification } \\ \text { USDA } & \text { U.S. Department of Agriculture } \\ \text { USEPA } & \text { U.S. Environmental Protection Administration } \\ \text { USGS } & \text { U.S. Geological Survey } \\ \text { WSO } & \text { Weather Station Observatory } \\ \text { WWTF } & \text { Wastewater-Treatment Facility } \\ & \end{array}$





\title{
Estimated Water Use and Availability in the Pawtuxet and Quinebaug River Basins, Rhode Island, 1995-99
}

\author{
ByEmily C. Wild and Mark T. Nimiroski
}

\section{Abstract}

Water availability became a concern in Rhode Island during a drought in 1999, and an investigation was needed to assess demands on the hydrologic system from withdrawals during periods of little to no precipitation. The low water levels during the drought prompted the U.S. Geological Survey and the Rhode Island Water Resources Board to begin a series of studies on water use and availability in each drainage area in Rhode Island for 1995-99. The study area for this report, which includes the Pawtuxet River Basin in central Rhode Island (231.6 square miles) and the Quinebaug River Basin in western Rhode Island (60.97 square miles), was delineated as the surface-water drainage areas of these basins.

During the study period from 1995 through 1999, two major water suppliers withdrew an average of 71.86 million gallons per day (Mgal/d) from the Pawtuxet River Basin; of this amount, about $35.98 \mathrm{Mgal} / \mathrm{d}$ of potable water were exported to other basins in Rhode Island. The estimated water withdrawals from minor water suppliers were $0.026 \mathrm{Mgal} / \mathrm{d}$ in the Pawtuxet River Basin and 0.003 Mgal/d in the Quinebaug River Basin. Total self-supply withdrawals were $2.173 \mathrm{Mgal} / \mathrm{d}$ in the Pawtuxet River Basin and 0.360 Mgal/d in the Quinebaug River Basin, which has no public water supply. Total water use averaged 18.07 Mgal/d in the Pawtuxet River Basin and 0.363 $\mathrm{Mgal} / \mathrm{d}$ in the Quinebaug River Basin. Total return flow in the Pawtuxet River Basin was 30.64 Mgal/d, which included about $12.28 \mathrm{Mgal} / \mathrm{d}$ that were imported from other basins in Rhode Island. Total return flow was $0.283 \mathrm{Mgal} / \mathrm{d}$ in the Quinebaug River Basin.

During times of little to no recharge in the form of precipitation, the surface- and ground-water flows are from storage primarily in the stratified sand and gravel deposits; water also flows through the till deposits, but at a slower rate. The ground water discharging to the streams during times of little to no recharge from precipitation is referred to as base flow. The PART program, a computerized hydrograph-separation application, was used to analyze the data collected at two selected index stream-gaging stations to determine water availability on the basis of the 75th, 50th, and 25th percentiles of the total base flow; the base flow for the 7-day, 10-year low-flow scenario; and the base flow for the Aquatic Base Flow scenario for both stations. The index stream-gaging stations used in the analysis were the Branch River at Forestdale, Rhode Island (period of record 1957-1999) and the Nooseneck River at Nooseneck, Rhode Island (period of record 1964-1980). A regression equation was used to estimate unknown base-flow contributions from sand and gravel deposits at the two stations. The base-flow contributions from sand and gravel deposits and till deposits at the index stations were computed for June, July, August, and September within the periods of record, and divided by the area of each type of surficial deposit at each index station. These months were selected because they define a period when there is usually an increased demand for water and little to no precipitation. The base flows at the stream-gaging station Branch River at Forestdale, Rhode Island were lowest in August at the 75 th, 50th, and 25th percentiles $(29.67,21.48$, and 13.30 $\mathrm{Mgal} / \mathrm{d}$, respectively). The base flows at the stream-gaging station Nooseneck River at Nooseneck, Rhode Island were lowest in September at the 75 th percentile $(3.551 \mathrm{Mgal} / \mathrm{d})$ and lowest in August at the 50th and 25th percentiles (2.554 and 1.811 $\mathrm{Mgal} / \mathrm{d}$ ).

The base flows per unit area for the index stations were multiplied by the areas of sand and gravel and till in the studyarea subbasins to determine the amount of available water for each scenario. The water availability in the Pawtuxet River Basin at the 50th percentile ranged from $126.5 \mathrm{Mgal} / \mathrm{d}$ in August to $204.7 \mathrm{Mgal} / \mathrm{d}$ in June, and the total gross water availability for the 7-day, 10-year low-flow scenario at the 50th percentile ranged from 112.2 Mgal/d in August to $190.4 \mathrm{Mgal} / \mathrm{d}$ in June. The Scituate Reservoir safe yield was $83 \mathrm{Mgal} / \mathrm{d}$ in all scenarios. Water availability in the Quinebaug River Basin ranged from $13.94 \mathrm{Mgal} / \mathrm{d}$ in August to $30.53 \mathrm{Mgal} / \mathrm{d}$ in June at the 50th percentile. The total gross water availability for the 7-day, 10-year low-flow scenario at the 50th percentile ranged from 14.26 Mgal/d in August to 42.69 Mgal/d in June.

Because water withdrawals and use are greater during the summer than other times of the year, water availability in June, July, August, and September was compared to water withdrawals in the basin and subbasins. The ratios of water withdrawn to water available were calculated for the $75 \mathrm{th}, 50 \mathrm{th}$, and 25 th percentiles for the subbasins; the closer the ratio is to 1, the closer the withdrawals are to the estimated water available, and the less net water is available. Withdrawals in July were higher than in the other summer months in both basins. In the Pawtuxet River Basin, the ratios were close to 1 in July for the estimated gross yield (from sand and gravel and from till and from the Scituate Reservoir safe yield), 7-day, 10-year low-flow scenario, and Aquatic Base Flow scenario at the 75 th percentile and in 


\section{Estimated Water Use and Availability in the Pawtuxet and Quinebaug River Basins, Rhode Island, 1995-99}

August for all three scenarios at the 50th and 25th percentiles. In the Quinebaug River Basin, the ratios were close to 1 in August for the estimated gross yield; 7-day, 10-year low-flow scenario; and Aquatic Base Flow scenario.

A long-term water budget was calculated for 1941 through 1999 to identify and assess the basin and subbasin inflow and outflows for the Pawtuxet and Quinebaug River Basins. The water withdrawals and return flows used in the budget were from 1995 through 1999. Inflow was assumed to be equal to outflow; total inflows and outflows were $574.9 \mathrm{Mgal} / \mathrm{d}$ in the Pawtuxet River Basin and 148.4 Mgal/d in the Quinebaug River Basin. Precipitation and return flow were 95 and 5 percent of the estimated inflows to the Pawtuxet River Basin, respectively. Precipitation was 100 percent of the estimated inflow to the Quinebaug River Basin; return flow was less than 1 percent of the inflow. Evapotranspiration, streamflow, and water withdrawals were 46, 41, and 13 percent, respectively, of the estimated outflows in the Pawtuxet River Basin. Evapotranspiration and streamflow were 49 and 51 percent, respectively, of the estimated outflows in the Quinebaug River Basin. Water withdrawals were less than 1 percent of outflows in the Quinebaug River Basin.

\section{Introduction}

Water availability became a concern to the State of Rhode Island during a drought in 1999, and an investigation was needed to assess water use and availability in the state, including the Pawtuxet and Quinebaug River Basins (fig. 1). During the summer of 1999, the average precipitation at the Kingston, RI, climatological station for June was only about 0.05 in., compared to the 30-year (1971-2000) long-term average precipitation of 3.936 in. for June. Because precipitation is a key component of surface-water runoff and ground-water infiltration (fig. 2), the rain deficiency caused a period of little to no recharge. As a result, ground-water levels and streamflows dropped below their long-term averages throughout Rhode Island.

To address water use and availability concerns in Rhode Island, the U.S. Geological Survey (USGS) began a series of nine water use and availability investigations in different basins for 1995-99 in cooperation with the Rhode Island Water Resources Board (RIWRB), which serves as a water-sourcing agency to ensure future water availability for residential growth and economic development for all Rhode Islanders (Rhode Island Water Resources Board, 2003). The purpose of the nine studies was to determine the relations between the water-use components (fig. 3) and the components of the hydrologic cycle (surface and ground water) during periods of little to no recharge. This particular study focused on the Pawtuxet and Quinebaug River Basins in central and western Rhode Island, respectively. Results of the Pawtuxet and Quinebaug River Basins studies and additional studies of other basins in or adjacent to Rhode Island will be used to compare water demands to water availability for times of little to no recharge, particularly during June, July, August, and September.

\section{Purpose and Scope}

This report identifies the water-use components and estimates water use and availability in the Pawtuxet and Quinebaug River Basins for calendar years 1995-99. To estimate water use, data for the components of water use were collected by basin and subbasin for the towns in the Pawtuxet and Quinebaug River Basins. The information and data on water withdrawals, use, and discharges were organized and retrieved by using the New England Water-Use Data System (NEWUDS) for the study period. The report presents the results of the calculated water availability for the Pawtuxet and Quinebaug River Basins for periods of little to no recharge by determining ground-water discharge during streamflowrecession periods and by using the previously published safe yield for the Scituate Reservoir (Weston, 1990). Because there are no major public water suppliers, wastewater collections, or interbasin transfers in the Quinebaug River Basin, discussion of these topics pertains only to the Pawtuxet River Basin. Water budgets, however, are presented for both basins. These budgets summarize the components of the hydrologic cycle on the basis of the long-term period of record for both basins (59 years) and selected water-use components for the study period.

\section{Previous Investigations}

The USGS has been collecting streamflow data from partial and continuous stream-gaging stations in the Pawtuxet River Basin for more than 63 years, and has been monitoring ground-water levels for more than 59 years. The data collected in the basin and its subbasins have been used for numerous hydrologic studies. Many studies have focused on the groundwater and surface-water resources and the water quality in the Pawtuxet River Basin and its subbasins. The Pawtuxet River Basin occupies areas within the Chepachet, Clayville, Coventry Center, Crompton, East Greenwich, East Killingly, Georgiaville, Hope Valley, North Scituate, Providence, Slocum, and Thompson USGS quadrangles. These quadrangles are published in the form of detailed thematic maps in reports describing the surficial geology (Feininger, 1962; Power, 1957; Richmond, 1953; Robinson, 1961; Smith, 1955; Smith, 1956a; and Smith, 1956b) and bedrock geology (Barosh, 1976; Dixon, 1974; Moore, 1958; Moore, 1963; Power, 1959; Quinn, 1951; Quinn, 1952; Quinn, 1959; Richmond, 1952). The Quinebaug River Basin occupies areas within the East Killingly, Oneco, Oxford, Thompson, and Voluntown USGS quadrangles. The surficial geology of the basin is described in quadrangle-map reports by Feininger (1965b) and Harwood and Goldsmith (1971b), and the bedrock geology in similar reports by Dixon (1974), Feininger (1965a), Harwood and Goldsmith (1971a), and Moore (1963). 


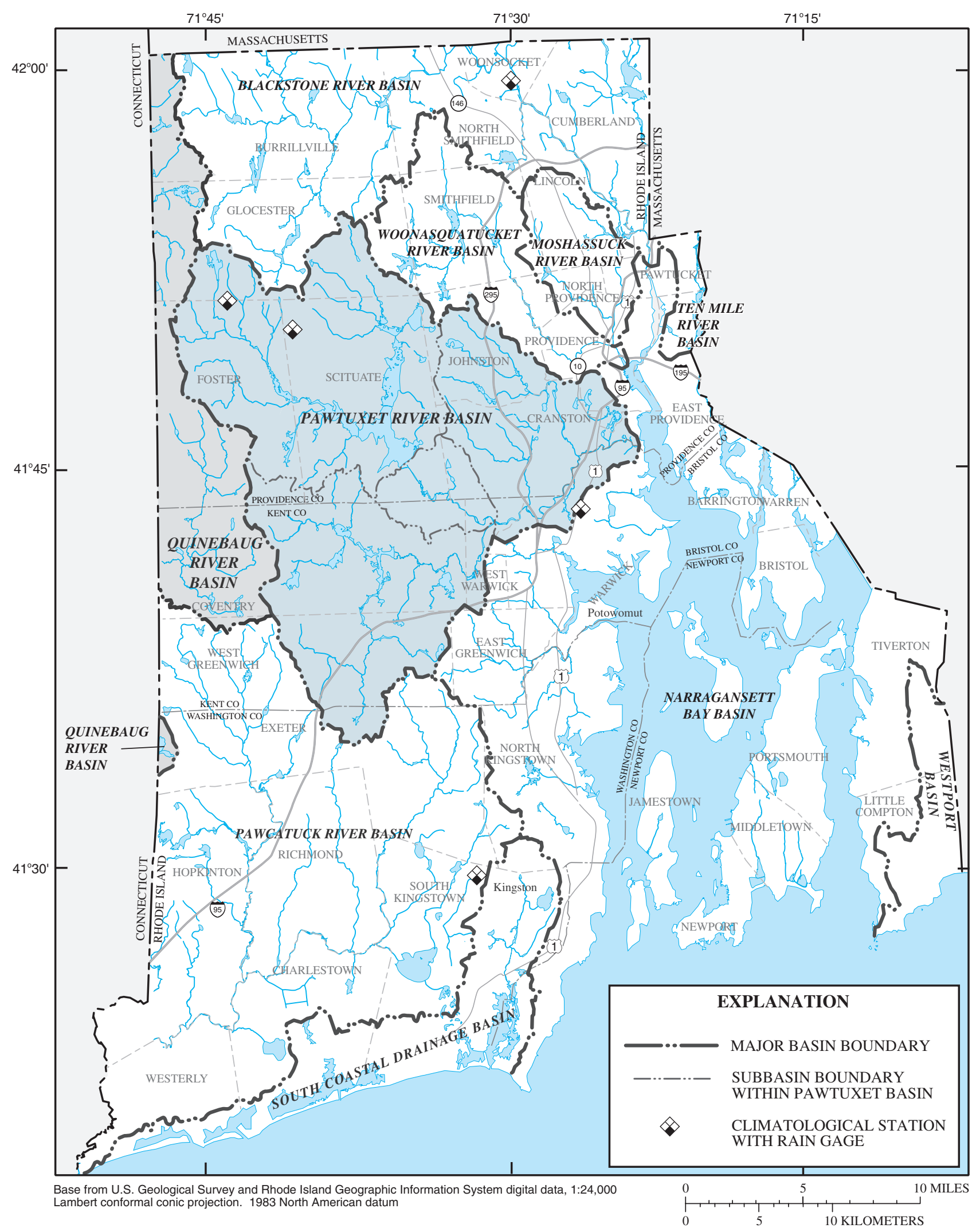

Figure 1. Towns and climatological stations in the Pawtuxet River Basin, central Rhode Island, and Quinebaug River Basin, western Rhode Island. 


\section{THE HYDROLOGIC CYCLE}

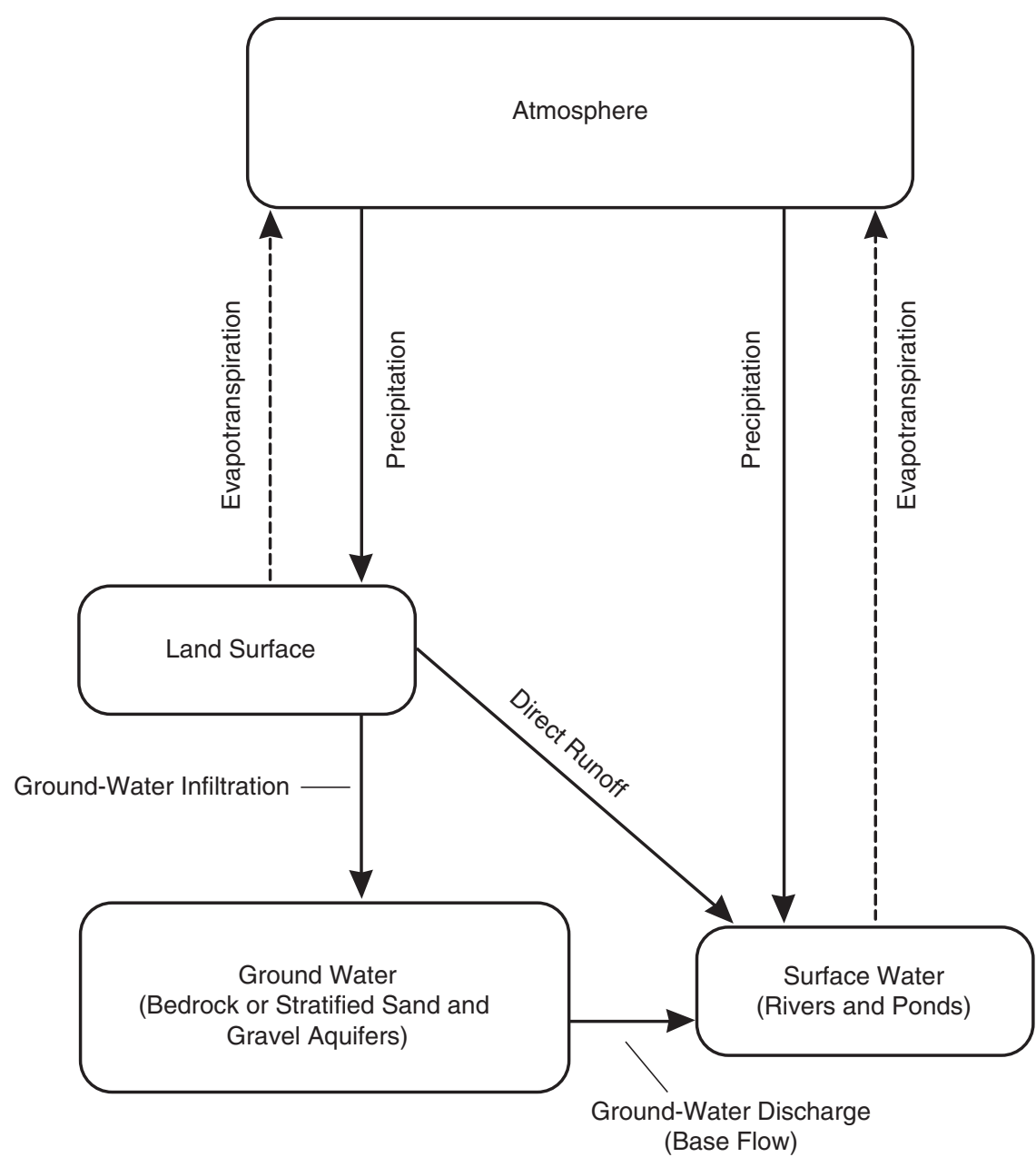

Figure 2. The hydrologic cycle. (Modified from U.S. Geological Survey, 2004). 


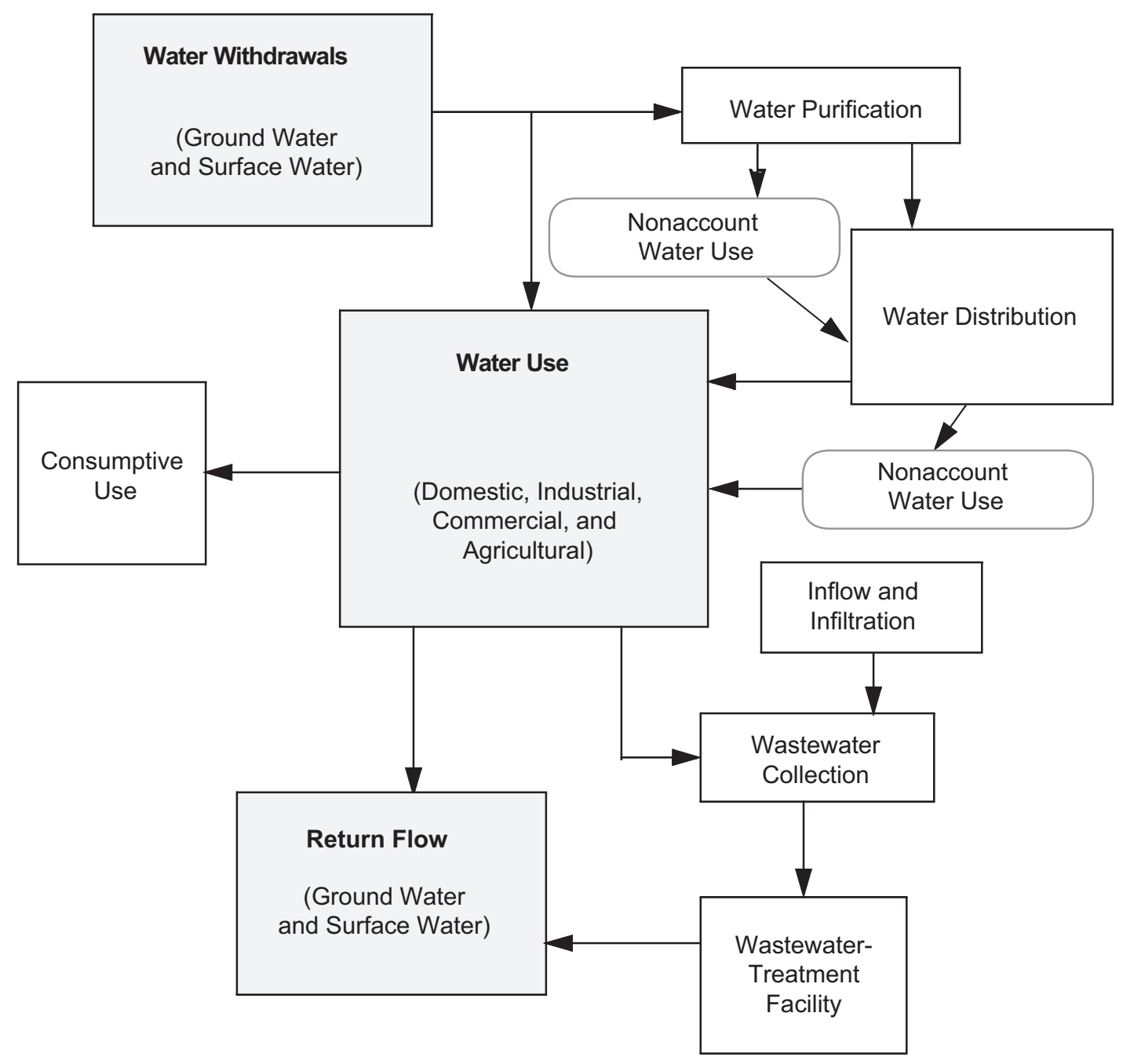

Figure 3. The components of water use. 


\section{Estimated Water Use and Availability in the Pawtuxet and Quinebaug River Basins, Rhode Island, 1995-99}

The Rhode Island Water Resources Geologic Bulletin report series provides information about well records, lithologic logs, water-quality assessments, hydrologic characteristics of the surficial deposits (till and stratified sand and gravel deposits), and water-table altitudes. The Geologic Bulletin reports used in this assessment include Allen (1956), Bierschenk (1959), Hahn (1961), Richmond and Allen (1951), Roberts and Brashears (1945), and Roberts and Halberg (1945). The Rhode Island Water Resources Ground-Water Map report series provides information about bedrock contours, water-table altitudes, well locations, and till and stratified sand and gravel deposits. Ground-water maps used in this assessment include Allen and others (1959), Bierschenk and Hahn (1959), Hahn (1959), Hahn and Hansen (1961), Hansen (1962a, 1962b), Johnson (1962), Mason and Hahn (1960), and Pollock (1960). Details about partial-record stations can be found in the USGS annual data report series (Socolow and others, 2001), in studies of the Scituate Basin (Breault and others, 2000; and Nimiroski and Waldron, 2002), and in a recent summary of stream-gaging stations and ground-water monitoring wells (Zarriello and Socolow, 2003). Limited data about ground water (Allen, 1953; Allen and Lang, 1957; Kliever, 1995; Lang, 1961) and surface water (Allen, 1953) are available for the Quinebaug River Basin in Rhode Island.

In addition to studies pertaining to surficial deposits in the basin and subbasins, water-use data for the Pawtuxet and Quinebaug River Basins have been published in statewide assessments (Craft and others, 1995; Horn, 2000; Horn and Craft, 1991; and Medalie, 1996). Previous investigations in this series of USGS water use and availability studies (Barlow, 2003; and Nimiroski and Wild, 2005) contain additional information on wholesale purchases for districts within the Blackstone, Woonasquatucket, and Moshassuck River Basins from the Pawtuxet River Basin. The public water suppliers submit individual water-supply management plans to the RIWRB as a part of the state's Water Supply Systems Management Plan. Information on public disposal was collected (oral and written communication) from wastewater assessments that have been completed and submitted to the Rhode Island Department of Environmental Management (RIDEM), Office of Water Resources.

\section{Climatological Setting}

The National Oceanic and Atmospheric Administration has been publishing precipitation and temperature data from the climatological stations in Rhode Island for more than 100 years (fig. 1). Data have been collected continuously at some of the climatological stations, whereas other stations have had months-long breaks in operation. The breaks in the record make it difficult to assess accurately the annual precipitation and trends in the average monthly precipitation and temperature through the period of record.

Precipitation data for the climatological stations at Kingston, Rhode Island, on the University of Rhode Island (URI) campus; the Providence Weather Station Observatory (WSO) at the airport in Warwick, Rhode Island; at North Foster, Rhode Island; and at North Scituate, Rhode Island, were compiled by using the monthly and annual summaries published in the series "Climatological Data New England" (National Oceanic and Atmospheric Administration, 2000), and are presented in table 1. These data were used to calculate components of water use and the hydrologic cycle. Statewide, total annual precipitation is about 47.98 in., the average annual temperature is about $50.08^{\circ} \mathrm{F}$ (National Oceanic and Atmospheric Administration, 2000 and 2002), and the climate is humid and temperate. For June, July, August, and September, long-term (1971-2000) trends in average precipitation differ substantially from trends during the study period (table 1). During the study period, the total annual precipitation was about 48.92 in., and the average annual temperature was about $50.96^{\circ} \mathrm{F}$. The Kingston climatological station has the longest precipitation record (1889-2005) of all of the Rhode Island climatological stations. The total annual precipitation at the Kingston climatological station for the study period was 53.11 in., and the average monthly precipitation for the summer ranged from 2.728 in. (July) to 4.474 in. (September). In addition to precipitation data from the stations operated by the National Oceanic and Atmospheric Administration, data from a network of precipitation stations operated by the Providence Water Supply Board (ProvWater) were used in calculating water budgets for 1941-99 (Providence Water Supply Board, written commun., 2000).

\section{The Pawtuxet River Basin}

The Pawtuxet River Basin in central Rhode Island (fig. 4) has a land area of about $231.6 \mathrm{mi}^{2}$. Thirteen Rhode Island towns are partially within the study area. In 1990, the basin population was about 196,121, and the estimated population during the study period was 194,963 (table 2). The Pawtuxet River Basin is mostly hilly, with higher altitudes in the northwest. For this study, the basin was divided into four subbasins - the Scituate Reservoir Complex, North Branch Pawtuxet, South Branch Pawtuxet, and Northeastern Pawtuxet subbasins (fig. 4) which are based on the surface-water drainage areas. Aquifers for this study were defined as areas of stratified sand and gravel deposits with more than $40 \mathrm{ft}$ of saturated thickness. One principal aquifer, the Mishnock aquifer, referred to as a groundwater reservoir in Rhode Island, is completely within the basin (fig. 5). The Providence-Warwick aquifer extends north to south along the coast of Narragansett Bay; the aquifer crosses the basin near the confluence of the Pawtuxet River with Narragansett Bay (fig. 5). Because limited data are available pertaining to the ground-water flow in this aquifer, the basin's surface-water divides were used for water-use and availability calculations. Losses from ground-water underflow within the defined surface-water drainage areas were considered negligible for this study. 
Table 1. Summary of National 0 ceanic and Atmospheric Administration climatological stations and data pertinent to the Pawtuxet River Basin, central Rhode Island, and to the Quinebaug River Basin, western Rhode Island, 1995-99.

[Locations of climatological stations are shown on fig. 1. Climatological data are from monthly and annual summaries from the National Climate Data Center of the National Oceanic and Atmospheric Administration, 1971-2000 (National Oceanic and Atmospheric Administration, 2000a and b). WSO, weather station observatory; ${ }^{\circ} \mathrm{F}$, degrees Fahrenheit; in., inches]

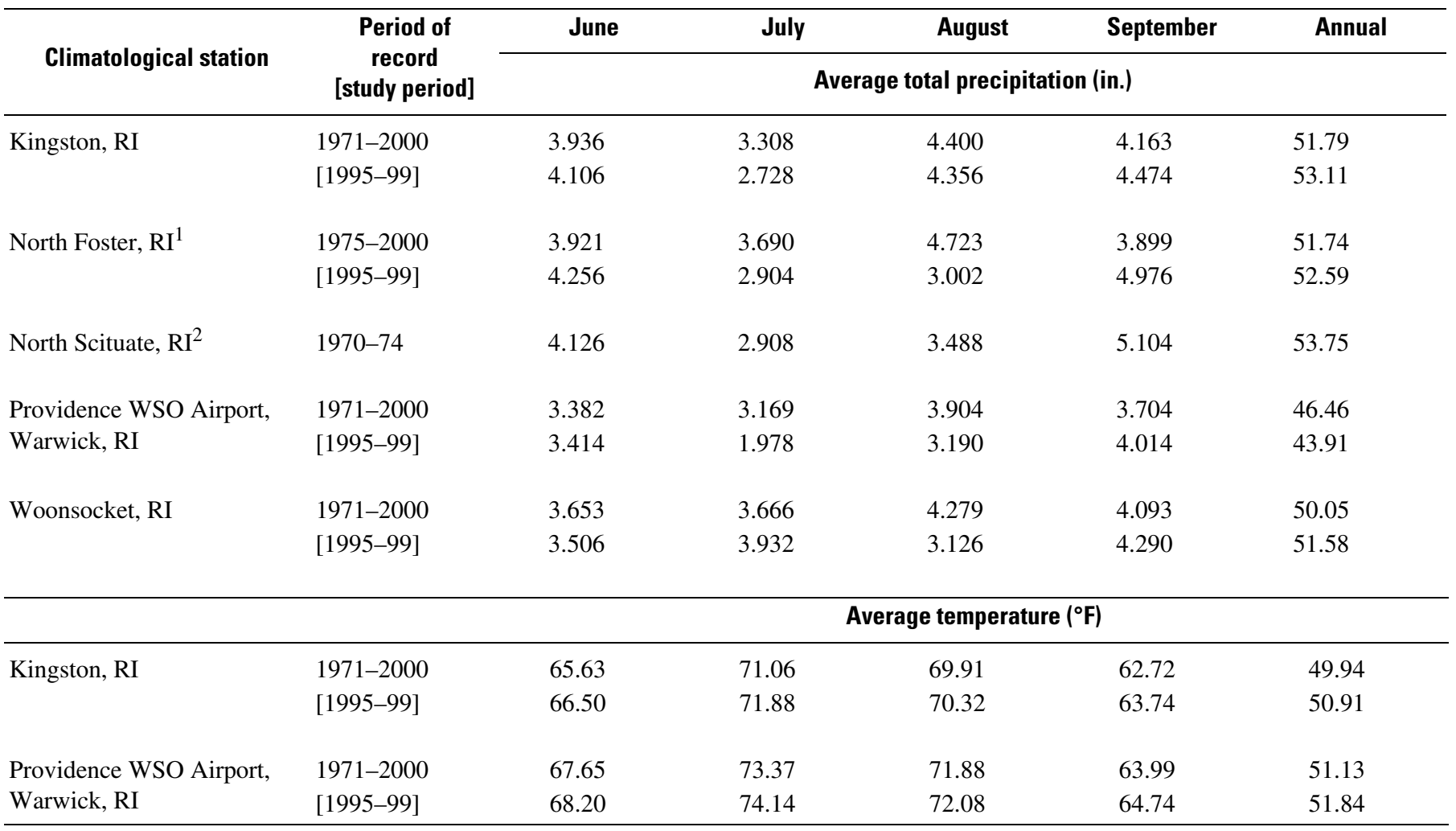

${ }^{1}$ North Foster station is missing precipitation data (September 1981, March 1982, July 1982, February 1983, March 1983, and January 1985), and therefore these data were not included in the monthly averages. No total annual precipitation data were available for the years $1981,1982,1983$, and 1985.

${ }^{2}$ North Scituate station was offline from October through December 1974, and therefore these data were not included in the monthly averages. No average total annual precipitation was calculated for 1974 .

\section{Land Use}

Land-use areas were calculated by merging the Rhode Island Geographic Information Systems (RIGIS) land-use coverages with the subbasin-boundary coverages. Land-use area was used as a tool to aggregate commercial, industrial, and agricultural water-use estimates by town, subbasin, and basin (table 3). If categorical data were available from the public-supply district, water use was disaggregated by subbasin on the basis of land-use area in the public-supply district (table 4). Land-use areas not within public-supply districts were assumed to be selfsupplied.

\section{Pawtuxet River Subbasins}

The surface-water-flow boundaries were used for assessing water use and determining water availability for the summer in the basin (fig. 4) because data on ground-water movement along the currently defined surface-water delineations are limited. Based on the surface-water-drainage boundaries, about
29.5 percent of the surficial geology in the Pawtuxet River Basin is stratified sand and gravel deposits. The thickness of the sand and gravel deposits is greater at the confluence of the Pawtuxet River Basin with Narragansett Bay, mainly because of the Providence-Warwick aquifer.

The USGS subbasin boundaries delineated for the study area are similar to the cataloging units defined in the Watershed Boundary Dataset (WBD) delineated by the Natural Resources Conservation Service (NRCS) in 2003 (table 5). The WBD used the standards for delineations of the boundaries that were established by the Federal Geographic Data Committee in 2002. The WBD cataloging units are compared visually to the areas used for this study in figure 6 . The main spatial difference between them is that the smaller drainage areas determined by the WBD are grouped together by segments for this study. Naming conventions are another difference between the study subbasins and the WBD 10-digit and WBD 12-digit cataloging units (table 5, fig. 6). The Pawtuxet River Basin is one of the WBD 10-digit cataloging areas within the USGS 8-digit Hydrologic Unit Code (HUC) area for the Narragansett Bay Basin. 
Table 2. Total town populations by subbasin for 1990, estimated populations for 1995-99, and estimated populations on public and selfsupply and on public and self-disposal in the Pawtuxet River Basin, central Rhode Island, and in the Quinebaug River Basin, western Rhode Island, 1995-99.

[Shaded areas are basin totals. Total populations in Rhode Island, 1990, from Rhode Island Geographic Information System (1991). Estimated 1995-99 population from the Rhode Island Economic Development Corporation (2001). --, not applicable]

\begin{tabular}{|c|c|c|c|c|c|c|}
\hline \multirow{3}{*}{ Towns } & \multicolumn{2}{|c|}{ Population } & \multicolumn{4}{|c|}{ Estimated 1995-99 population } \\
\hline & \multirow{2}{*}{1990} & \multirow{2}{*}{$\begin{array}{c}\text { Estimated } \\
1995-99\end{array}$} & \multicolumn{2}{|c|}{ Supply } & \multicolumn{2}{|c|}{ Disposal } \\
\hline & & & Public & Self & Public & Self \\
\hline \multicolumn{7}{|c|}{ Scituate Reservoir Complex Subbasin } \\
\hline Cranston & 144 & 142 & 97 & 45 & 16 & 126 \\
\hline Glocester & 2,799 & 2,815 & -- & 2,815 & -- & 2,815 \\
\hline Johnston & 978 & 971 & 432 & 539 & 41 & 930 \\
\hline Scituate & 7,832 & 8,006 & 431 & 7,575 & 238 & 7,768 \\
\hline Smithfield & 91 & 90 & -- & 90 & -- & 90 \\
\hline Subbasin total & 14,832 & 14,533 & 1,301 & 13,232 & 540 & 13,993 \\
\hline Scituate & 1,676 & 1,713 & 901 & 812 & 135 & 1,578 \\
\hline West Warwick & 6,036 & 5,986 & 5,952 & 34 & 5,526 & 460 \\
\hline Subbasin total & 12,581 & 12,729 & 11,054 & 1,675 & 6,084 & 6,645 \\
\hline \multicolumn{7}{|c|}{ South Branch Pawtuxet Subbasin } \\
\hline Coventry & 25,627 & 26,816 & 20,753 & 6,063 & 3,307 & 23,509 \\
\hline East Greenwich & 49 & 50 & 31 & 19 & 3 & 47 \\
\hline Exeter & 367 & 398 & 4 & 394 & -- & 398 \\
\hline Foster & 213 & 218 & -- & 218 & -- & 218 \\
\hline Scituate & 281 & 287 & -- & 287 & -- & 287 \\
\hline Johnston & 13,100 & 13,014 & 10,913 & 2,101 & 7,110 & 5,904 \\
\hline Providence & 25,417 & 23,957 & 23,957 & -- & 23,957 & -- \\
\hline Warwick & 17,349 & 17,061 & 17,054 & 7 & 11,560 & 5,501 \\
\hline West Warwick & 3,207 & 3,180 & 3,039 & 141 & 3,024 & 156 \\
\hline Subbasin total & 127,756 & 124,823 & 121,590 & 3,233 & 106,254 & 18,569 \\
\hline Basin total & 196,121 & 194,963 & 168,179 & 26,784 & 128,392 & 66,571 \\
\hline \multicolumn{7}{|c|}{ Quinebaug River Basin } \\
\hline Burrillville & 524 & 514 & -- & 514 & -- & 514 \\
\hline Coventry & 1,552 & 1,569 & 40 & 1,529 & -- & 1,569 \\
\hline Exeter & 75 & 81 & -- & 81 & -- & 81 \\
\hline Foster & 1,648 & 1,684 & -- & 1,684 & -- & 1,684 \\
\hline Glocester & 643 & 647 & -- & 647 & -- & 647 \\
\hline West Greenwich & 41 & 46 & -- & 46 & -- & 46 \\
\hline Basin total & 4,483 & 4,541 & 40 & 4,501 & -- & 4,541 \\
\hline
\end{tabular}




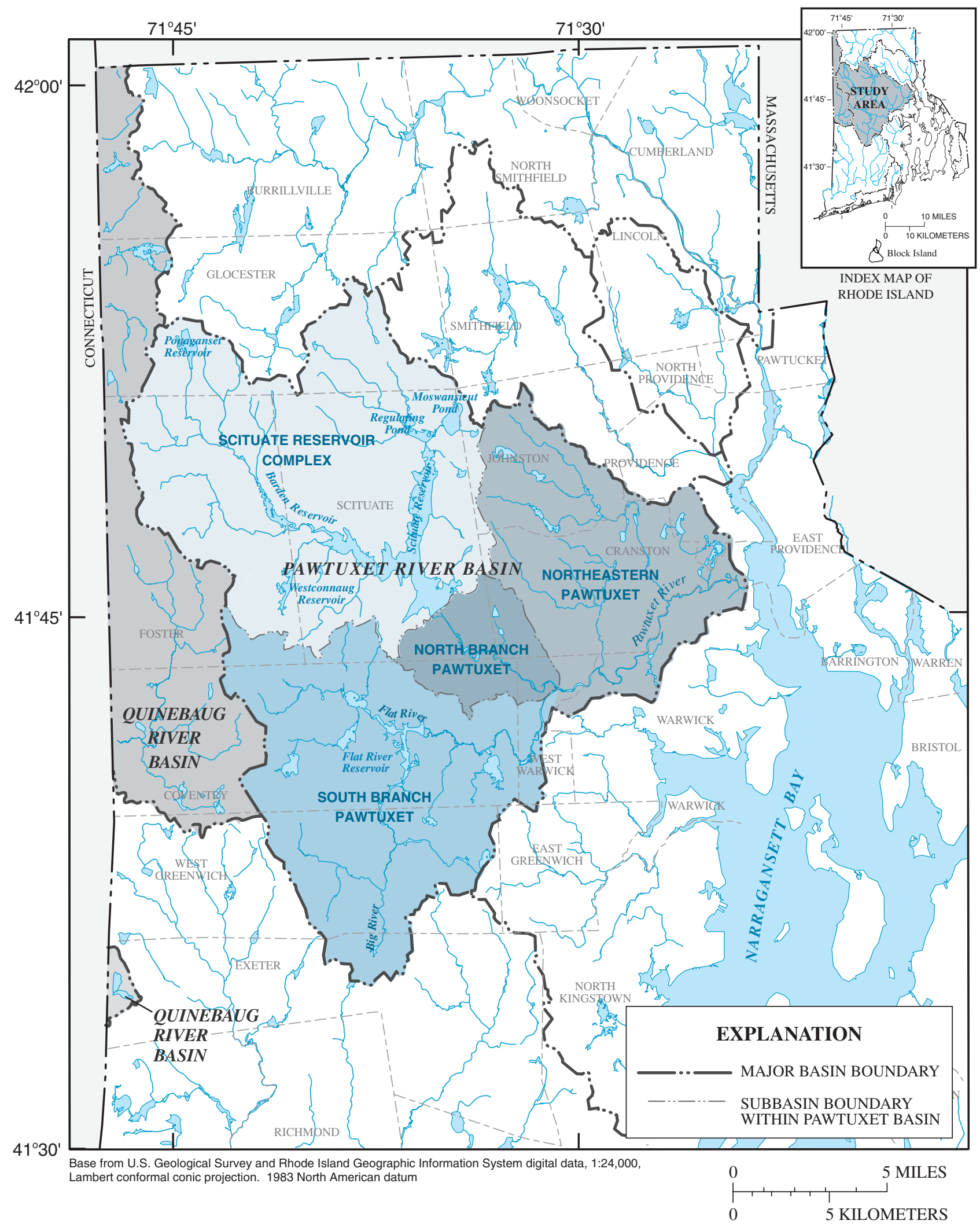

Figure 4. Subbasins in the Pawtuxet River Basin, central Rhode Island, and the Quinebaug River Basin, western Rhode Island. 


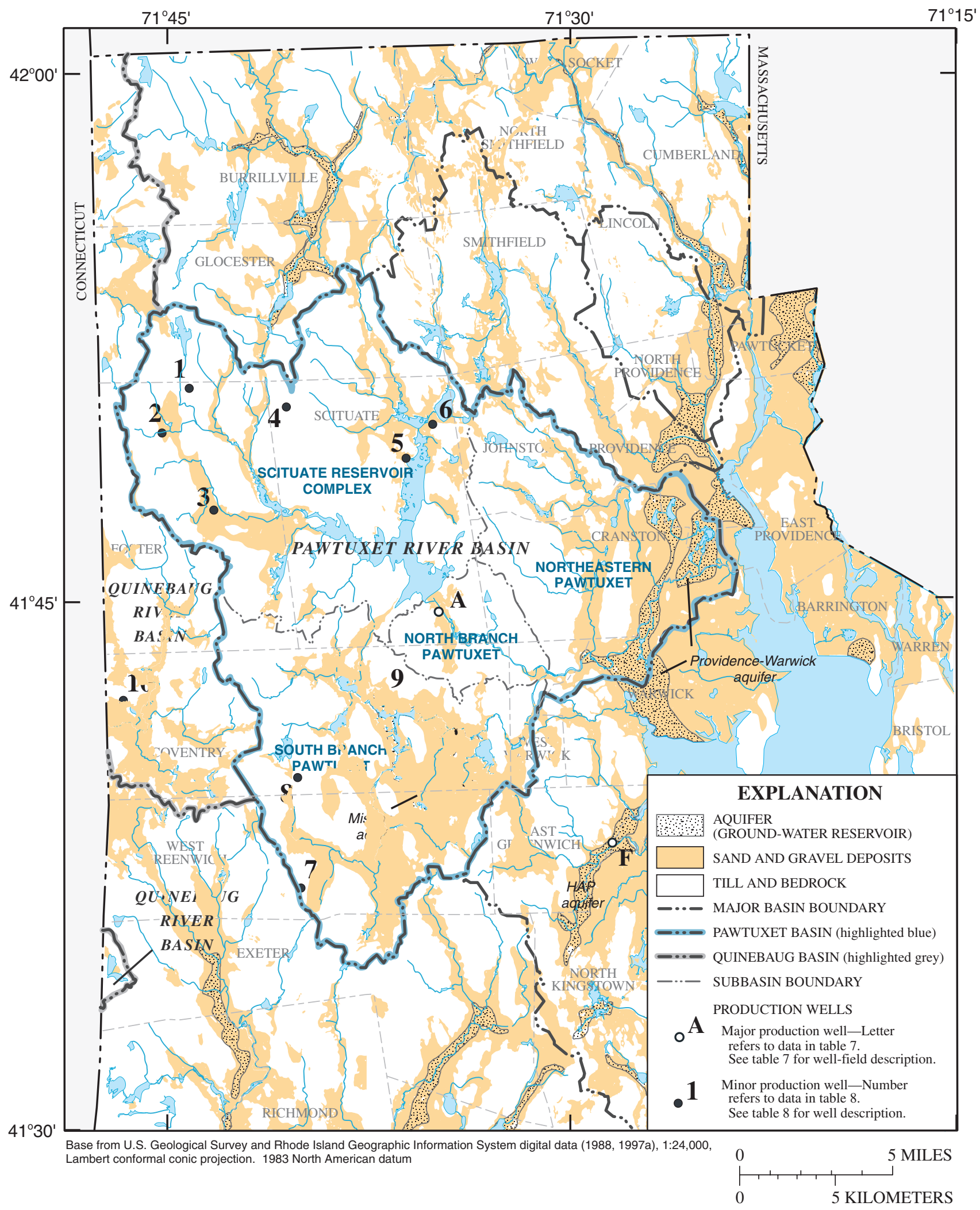

Figure 5. Aquifers and selected production wells for the subbasins in the Pawtuxet and Quinebaug River Basins, central and western Rhode Island. [HAP, Hunt-Annaquatucket-Pettaquamscutt] 
Table 3. Town land area and land-use area by category in the subbasins of the Pawtuxet River Basin, central Rhode Island, and in the Quinebaug River Basin, western Rhode Island, 1995-99.

[Shaded areas are basin totals. Land-use areas were estimated by using the coverage from the Rhode Island Geographic Information System (1995a). $\mathrm{mi}^{2}$, square mile; $<0.001$, value not included in totals; --, not applicable]

\begin{tabular}{ccccc}
\hline \multirow{3}{*}{ Town } & Land & \multicolumn{3}{c}{ Land-use area by category $\left(\mathrm{mi}^{2}\right)$} \\
\cline { 3 - 5 } & $\begin{array}{c}\text { area } \\
\left(\mathrm{mi}^{2}\right)\end{array}$ & $\begin{array}{c}\text { Commer- } \\
\text { cial }\end{array}$ & $\begin{array}{c}\text { Indus- } \\
\text { trial }\end{array}$ & $\begin{array}{c}\text { Agricul- } \\
\text { tural }\end{array}$ \\
\hline
\end{tabular}

Pawtuxet River Basin

\begin{tabular}{|c|c|c|c|c|}
\hline \multicolumn{5}{|c|}{ Scituate Reservoir Complex Subbasin } \\
\hline Cranston & 0.461 & -- & -- & 0.095 \\
\hline Foster & 28.95 & 0.170 & 0.042 & .950 \\
\hline Glocester & 16.39 & .066 & -- & 1.023 \\
\hline Johnston & 1.941 & .033 & .002 & .175 \\
\hline Scituate & 46.33 & .174 & .009 & 1.604 \\
\hline Smithfield & .032 & -- & -- & .003 \\
\hline Subbasin total & 94.11 & 0.443 & 0.053 & 3.850 \\
\hline \multicolumn{5}{|c|}{ North Branch Pawtuxet Subbasin } \\
\hline Coventry & 3.917 & 0.029 & 0.062 & 0.123 \\
\hline Cranston & 3.159 & .001 & .005 & .892 \\
\hline Scituate & 5.493 & .014 & .019 & .538 \\
\hline West Warwick & 1.525 & .093 & .080 & .035 \\
\hline Subbasin total & 14.09 & 0.137 & 0.166 & 1.588 \\
\hline \multicolumn{5}{|c|}{ South Branch Pawtuxet Subbasin } \\
\hline Coventry & 37.32 & 0.575 & 0.284 & 0.985 \\
\hline East Greenwich & .140 & -- & -- & -- \\
\hline Exeter & 3.247 & .008 & -- & .133 \\
\hline Foster & 2.902 & -- & -- & .083 \\
\hline Scituate & 2.967 & -- & -- & .172 \\
\hline Warwick & .043 & .001 & -- & .002 \\
\hline West Greenwich & 23.10 & .187 & .038 & .775 \\
\hline West Warwick & 2.958 & .247 & .144 & .017 \\
\hline Subbasin total & 72.68 & 1.018 & 0.466 & 2.167 \\
\hline \multicolumn{5}{|c|}{ Northeastern Pawtuxet Subbasin } \\
\hline Cranston & 24.56 & 1.141 & 1.155 & 1.622 \\
\hline Johnston & 14.60 & .508 & .269 & .971 \\
\hline Providence & 2.952 & .279 & .395 & -- \\
\hline Warwick & 7.140 & 1.014 & .874 & .058 \\
\hline West Warwick & 1.460 & .054 & .020 & .031 \\
\hline Subbasin total & 50.71 & 2.996 & 2.713 & 2.682 \\
\hline Basin total & 231.6 & 4.594 & 3.398 & 2.682 \\
\hline \multicolumn{5}{|c|}{ Quinebaug River Basin } \\
\hline Burrillville & 8.595 & -- & -- & 0.047 \\
\hline Coventry & 20.30 & 0.023 & 0.009 & 1.284 \\
\hline Exeter & 1.432 & -- & -- & -- \\
\hline Foster & 20.09 & .077 & -- & 1.746 \\
\hline Glocester & 9.703 & .027 & .037 & .278 \\
\hline West Greenwich & .853 & -- & -- & .006 \\
\hline Basin total & 60.97 & 0.127 & 0.046 & 3.361 \\
\hline
\end{tabular}

The Scituate Reservoir Complex subbasin $\left(94.11 \mathrm{mi}^{2}\right.$ drainage area) is in the western section of the Pawtuxet River Basin. The towns in the subbasin include Cranston, Foster, Glocester, Johnston, Scituate, and Smithfield (fig. 4). The Scituate Reservoir Complex subbasin is a headwater subbasin defined by the Gainer Dam embankment at the confluence with the North Branch Pawtuxet River. The complex includes the drainage areas for five reservoirs - the Ponaganset, Barden, Westconnaug, Regulating, and Moswansicut Reservoirs - which drain into the drainage area of the Scituate Reservoir (fig. 7), and comprises three 12-digit cataloging units defined by the WBD (fig. 6 and table 5). The Ponaganset River flows southeast from the Ponaganset Reservoir dam and into the Barden Reservoir. Hemlock Brook flows east into Barden Reservoir, which drains to the Scituate Reservoir at the confluence of Swamp Brook. Just south of the Barden Reservoir confluence, the Westconnaug Brook flows from the Westconnaug Reservoir into the Scituate Reservoir. In the northern part of the Scituate Reservoir Complex subbasin, Peeptoad, Huntinghouse, and Rush Brooks flow into the Regulating Reservoir. In the northeastern corner of the Scituate Reservoir Complex subbasin, drainage from the Moswansicut Reservoir flows west into the Regulating Reservoir. Other tributaries to the Scituate Reservoir include Brandy Brook from the east, Cork Brook from the north, Kent Brook from the east, Spruce Brook from the north, Quonapaug Brook from the east, and Wilbur Hollow Brook from the southwest. Although no defined aquifers are in the Scituate Reservoir Complex subbasin, about 17.4 percent of the glacial deposits are stratified sand and gravel deposits (figs. 5 and 7). One continuous stream-gaging station (fig. 8), the Ponaganset River at South Foster, Rhode Island (01115187), has a period of record of more than 8 years, and the surficial deposits in the area upstream of the stream-gaging station are about 15 percent sand and gravel. The USGS has been collecting surfacewater data from partial-record stations within the Scituate Reservoir Complex subbasin in cooperation with ProvWater for about 10 years (fig. 7).

The North Branch Pawtuxet subbasin $\left(14.09 \mathrm{mi}^{2}\right.$ drainage area) is the central section of the Pawtuxet River Basin. The towns in the subbasin include Coventry, Cranston, Scituate, and West Warwick (fig. 4). Land areas and land-use areas by category for towns and major public water suppliers are summarized in tables 3 and 4, respectively. The North Branch Pawtuxet River flows southeast from Gainer Dam. Although the North Branch Pawtuxet subbasin has no defined aquifer, the area of the subbasin is about 12 percent sand and gravel (fig. 5); these deposits are the source of water for some self-supply users. One discontinued stream-gaging station in the subbasin (fig. 8), Pawtuxet River at Fiskeville, Rhode Island (01115500), has a period of record of more than 20 years. The surficial deposits in the area upstream of the Fiskeville station are about 12 percent sand and gravel, which is about the same as the percentage of sand and gravel deposits for the North Branch Pawtuxet subbasin. 


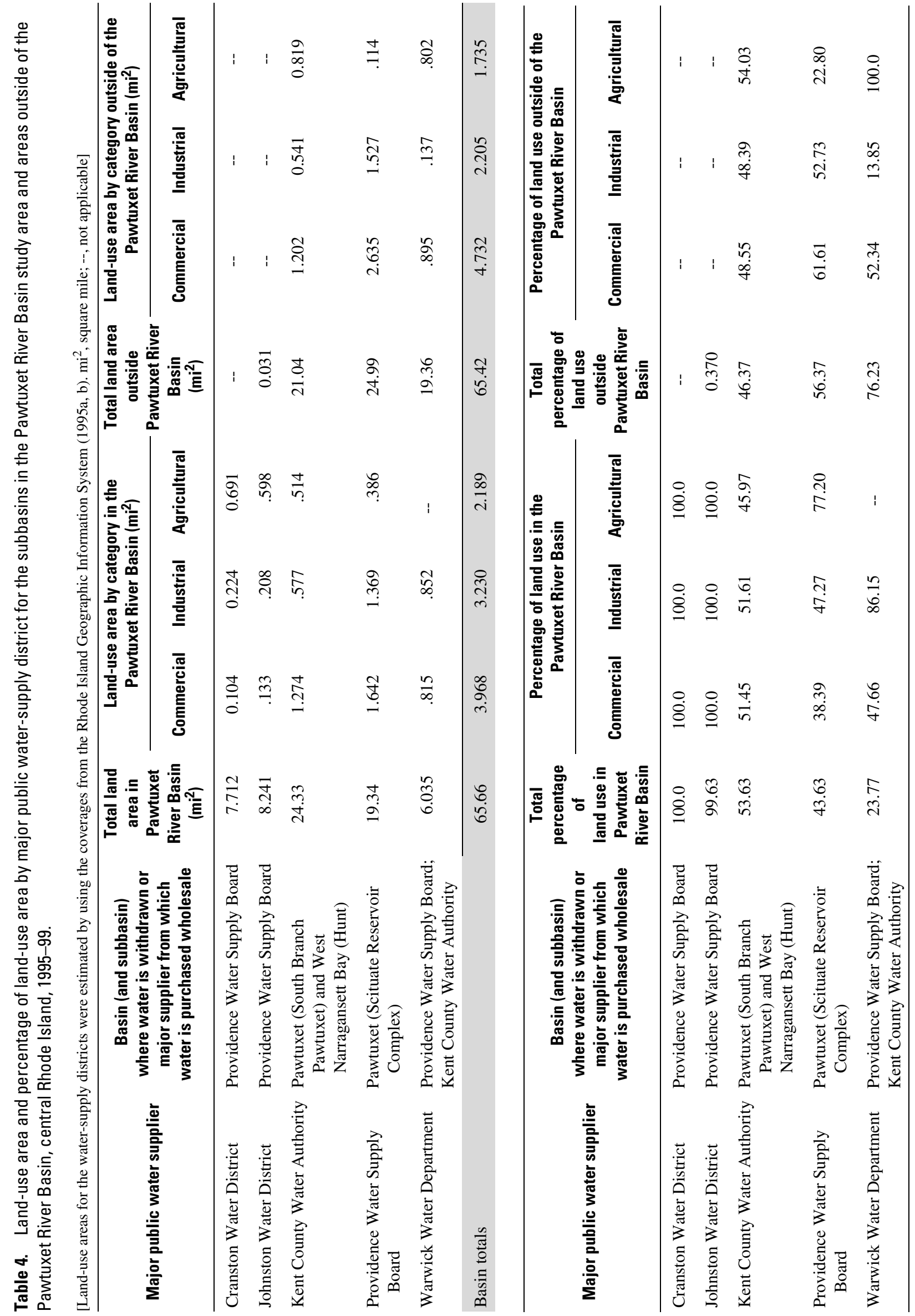




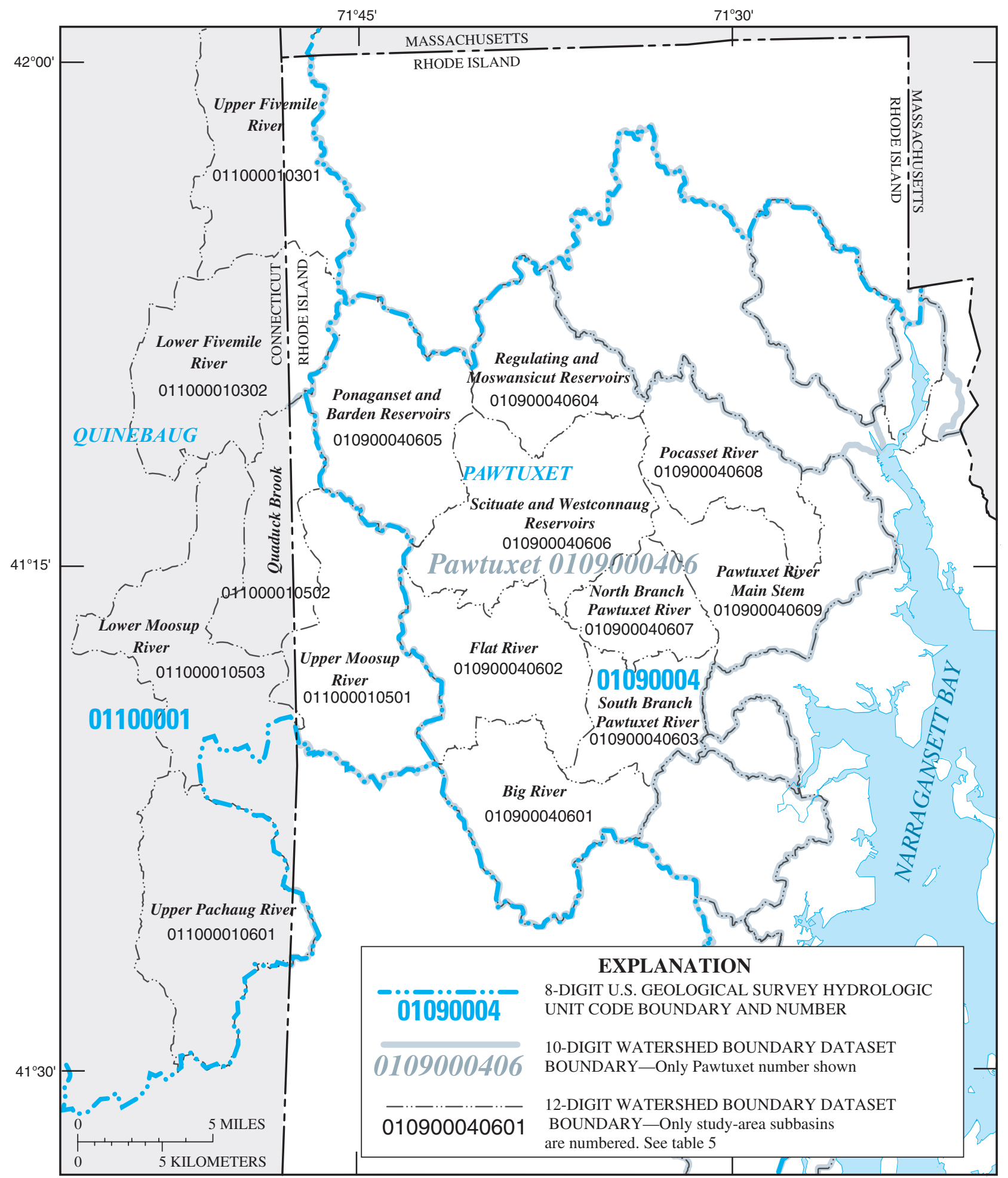

Base from U.S. Geological Survey, Connecticut Map and Geographic Information Center, and Rhode Island Geographic Information System data sets

Watershed Boundary Dataset from 1983 North American datum

Figure 6. The 8-, 10-, and 12-digit Watershed Boundary Dataset delineations for the Pawtuxet and Quinebaug River Basins, central and western Rhode Island. 


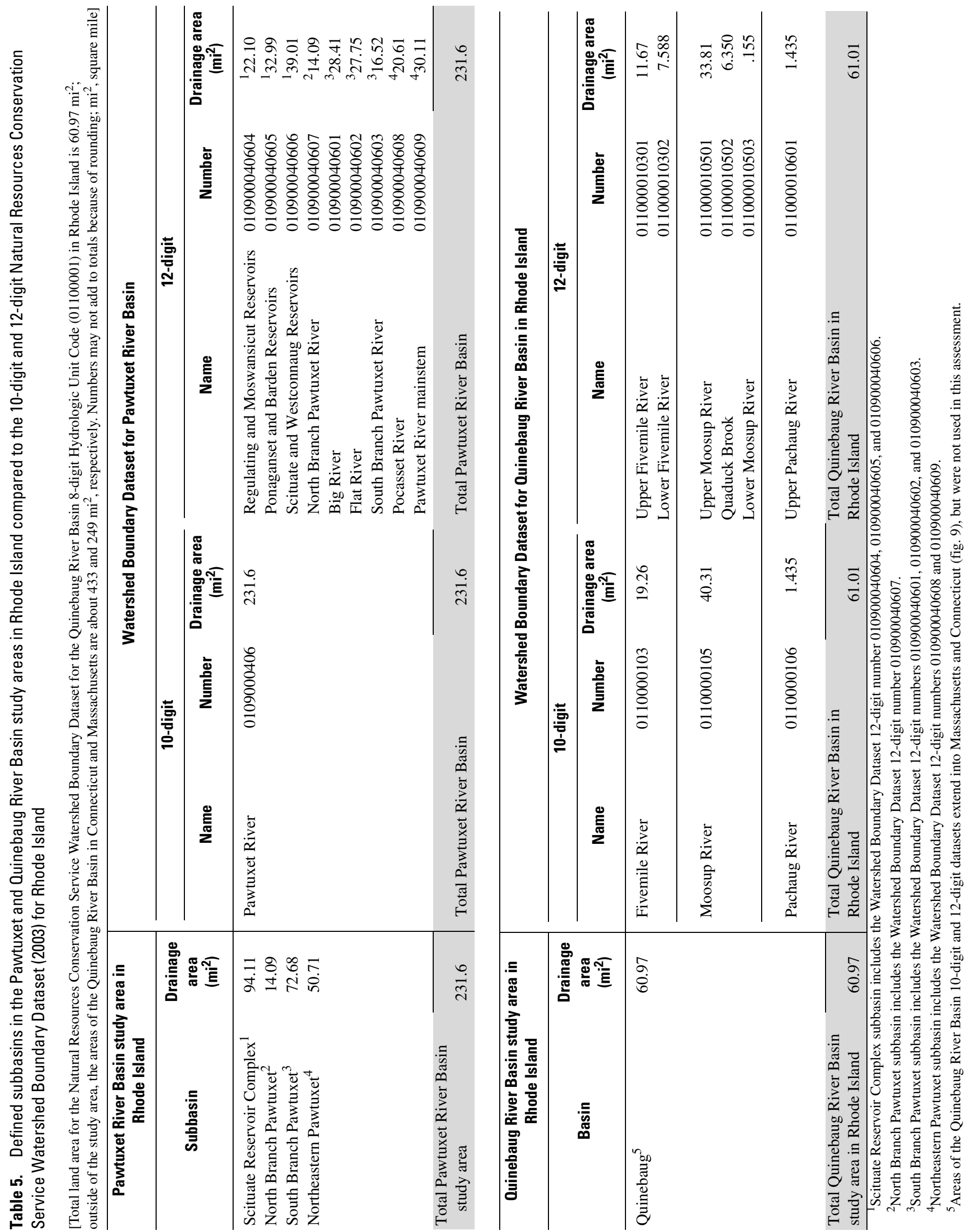




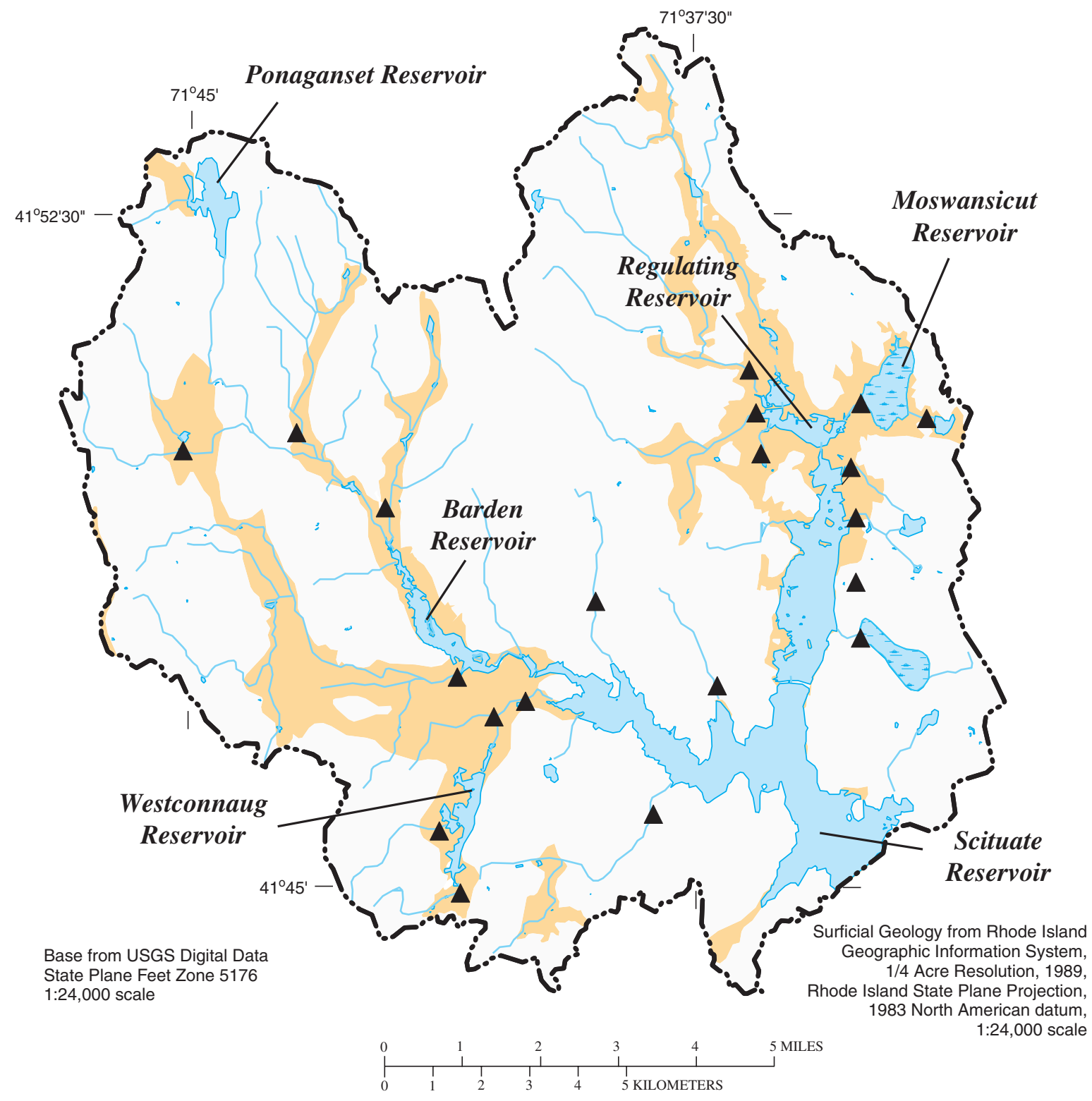

EXPLANATION

TILL AND BEDROCK

SAND AND GRAVEL DEPOSITS
SCITUATE RESERVOIR COMPLEX SUBBASIN BOUNDARY

U.S. GEOLOGICAL SURVEY PARTIAL-RECORD STREAM-GAGING STATIONS

Figure 7. Scituate Reservoir Complex subbasin with selected partial-record stream-gaging stations and surficial deposits, Pawtuxet River Basin, central Rhode Island. 


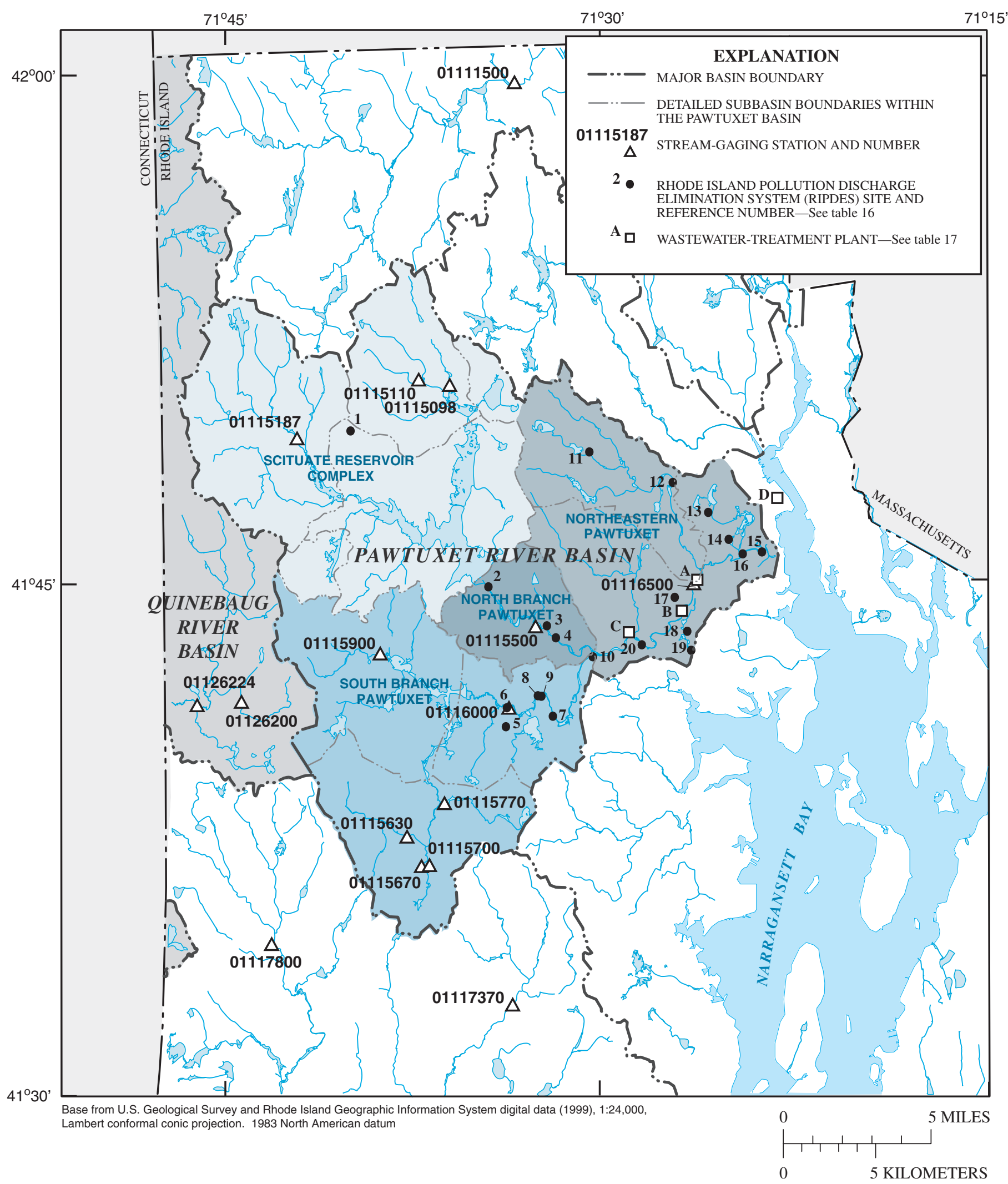

Figure 8. Stream-gaging stations, Rhode Island Pollutant Discharge Elimination System sites, and wastewater-treatment plants associated with the Pawtuxet and Quinebaug River Basins, central and western Rhode Island. 
The South Branch Pawtuxet subbasin $\left(72.68 \mathrm{mi}^{2}\right.$ drainage area) is in the southern section of the Pawtuxet River Basin. The towns in the subbasin are Coventry, East Greenwich, Exeter, Foster, Scituate, Warwick, West Greenwich, and West Warwick (fig. 4). In the southern part of the subbasin, the Nooseneck River flows into the Big River from the west, and the Carr River flows into the Big River from the east. The Big River flows north to the Flat River Reservoir in the western part of the subbasin. The reservoir is used for recreation, and the flow out of the reservoir is regulated by three flashboards, although no discharge data are collected. The outflow eastward from the reservoir is called the South Branch Pawtuxet River. The Mishnock River flows north from Lake Mishnock to its confluence with the South Branch Pawtuxet River. The main stem of the Pawtuxet River forms at the confluence of the South Branch Pawtuxet River and the North Branch Pawtuxet River.

The Mishnock aquifer is entirely within the South Branch Pawtuxet subbasin. The major public-supply withdrawals in the South Branch Pawtuxet subbasin are by the Kent County Water Authority, which withdraws water from the Mishnock aquifer (fig. 5). Self-suppliers withdraw water from the sand and gravel deposits, till deposits, and bedrock. Because the three major river and ground-water systems are hydrologically linked through the sand and gravel deposits in the subbasin, they were grouped together for estimations of water withdrawal, use, and availability in the subbasin. The area of the surficial deposits in the subbasin is 41 percent sand and gravel (fig. 5). The only continuous stream-gaging station in the subbasin is the South Branch Pawtuxet River at Washington (01116000) with a drainage area of $62.8 \mathrm{mi}^{2}$ (fig. 8). About 40 percent of the drainage area to this station is sand and gravel deposits. The USGS has been collecting surface-water data at this station for more than 63 years. Two discontinued stream-gaging stations, Nooseneck River at Nooseneck (01115630) and Carr River near Nooseneck (01115770) (fig. 8), have 17 and 16 years of record, respectively. The drainage areas for the Nooseneck River station and the Carr River station are $8.28 \mathrm{mi}^{2}$ and $7.33 \mathrm{mi}^{2}$, respectively. The percentages of sand and gravel deposits for the areas upstream of the stations are about 35 percent for the Nooseneck River station and 63 percent for the Carr River station.

The Northeastern Pawtuxet subbasin $\left(50.71 \mathrm{mi}^{2}\right.$ drainage area) is in the northeastern section of the Pawtuxet River Basin. The subbasin includes the towns of Cranston, Johnston, Providence, Warwick, and West Warwick (fig. 4). The subbasin includes the Pocasset River and the main stem of the Pawtuxet River. The Pocasset River flows southeast into the main stem of the Pawtuxet River in Cranston. The Pawtuxet River confluence with Narragansett Bay is in the easternmost part of the basin in the village of Pawtuxet. The surficial deposits in the subbasin are about 47 percent sand and gravel deposits. The USGS has been collecting surface-water data for more than 64 years at the one continuous stream-gaging station is in the subbasin (fig. 8), the Pawtuxet River at Cranston (01116500). Twenty-eight percent of the surficial deposits upstream of the station are sand and gravel.
The Providence-Warwick aquifer (fig. 5) is a defined ground-water source that extends along Narragansett Bay and crosses the Moshassuck, Woonasquatucket, Pawtuxet, and Narragansett Bay Basins in a north-south direction. Because data on this particular aquifer are limited, ground-water drainage divides were not used in the calculations of water use and availability. In addition, losses from lateral ground-water movement out of the basin were considered negligible for this study.

\section{Minor Civil Divisions}

The U.S. Census Bureau classifies towns and cities into minor civil divisions (MCDs). The 13 MCDs in the study area include Coventry, Cranston, East Greenwich, Exeter, Foster, Glocester, Johnston, Providence, Scituate, Smithfield, Warwick, West Greenwich, and West Warwick. Polygons within the towns were assigned population densities by using Census Bureau Topologically Integrated Geographic Encoding and Referencing (TIGER) system data available through RIGIS coverages. These 1990 population coverages were merged with the USGS basin and subbasin coverages to determine the population in the Pawtuxet River Basin and its subbasins (table 2). Also, town land area apportioned by basin and subbasin was determined by overlaying town boundaries and basin-boundary coverages (table 3). The population for a city or town was calculated by averaging the $1995,1996,1997,1998$, and 1999 populations estimated by the Rhode Island Economic Development Corporation (2001). The percentage of the total 1990 population for each town in each subbasins was applied to the estimated 1995-99 population for that town.

Public water suppliers are defined by the U.S. Environmental Protection Agency (USEPA) as suppliers serving more than 25 people or having 15 service connections year-round (U. S. Government Printing Office, 1996). Public suppliers were categorized into major public suppliers that have a system of distribution and minor public suppliers that have closed systems. The 1990 population on self-supply for the part of a town within a given subbasin was divided by the 1990 population for that part of the town. This procedure was repeated for the 1990 populations on public-wastewater collection. The resulting percentages of the 1990 populations on self-supply and wastewater collection in the subbasins for each town were applied to the 1995-99 populations to provide estimates of the 1995-99 populations on self-supply and public disposal (table 2). The 199599 populations on public supply and self-disposal were determined by subtracting the 1995-99 populations on self-supply and public disposal from the total 1995-99 populations in the subbasins for each town (table 2).

The town of Coventry is in central Rhode Island (fig. 1). The total land area is $62.45 \mathrm{mi}^{2}$, of which $41.24 \mathrm{mi}^{2}$ is in the Pawtuxet River Basin. The total town population in the basin for the study period (1995-99) was 30,815 out of a total town population of 32,523 (table 6). One major public water supplier, the Kent County Water Authority, supplies water to the eastern 


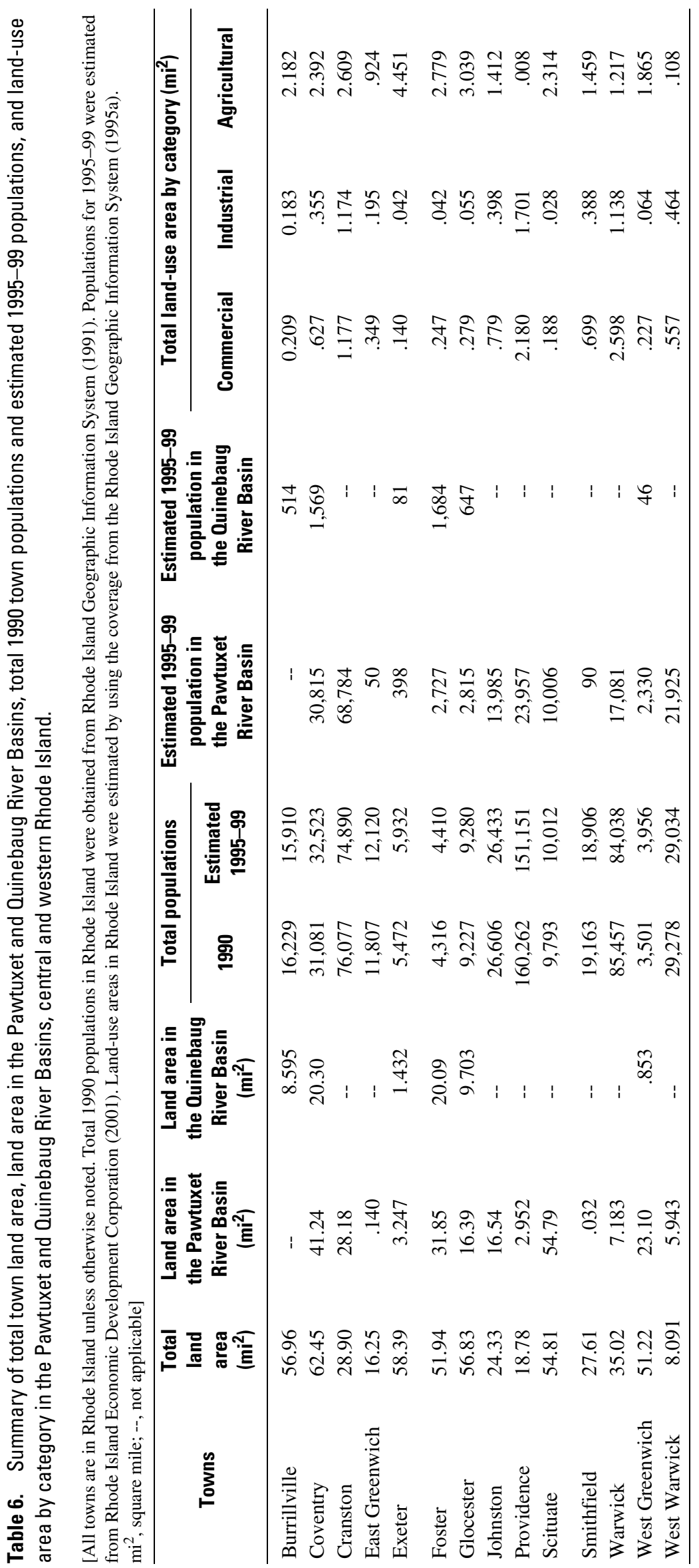


section of Coventry. Two minor public water suppliers serve small populations in the eastern part of the town in the Pawtuxet River Basin. The wastewater-collection area for the eastern section of Coventry is maintained by the West Warwick Regional Wastewater-Treatment Facility (WWTF).

The city of Cranston is in central Rhode Island (fig. 1). The total land area is $28.90 \mathrm{mi}^{2}$, of which $28.18 \mathrm{mi}^{2}$ is in the Pawtuxet River Basin. The total city population in the basin for the study period was 68,784 out of a total town population of 74,890 (table 6). The city purchases water from ProvWater. The interconnections with ProvWater that serve the part of the city west of Interstate 295 were maintained by the Cranston Water District until 1997. ProvWater also supplies Cranston's retail sales of water in the area east of Interstate 295; this area is part of ProvWater's retail-service area. The US Filter Cranston Water Pollution Control Facility and the West Warwick Regional WWTF collect and process wastewater for certain areas in Cranston.

The town of East Greenwich is in central Rhode Island (fig. 1). The total land area is $16.25 \mathrm{mi}^{2}$, of which $0.140 \mathrm{mi}^{2}$ is in the Pawtuxet River Basin. The total town population in the basin for the study period was 50 out of a total town population of 12,120 (table 6). The Kent County Water Authority supplies water to all of East Greenwich, and the East Greenwich WWTF collects wastewater for the community.

The town of Exeter is in south central Rhode Island (fig. 1). The total land area is $58.39 \mathrm{mi}^{2}$, of which $3.247 \mathrm{mi}^{2}$ is in the Pawtuxet River Basin. The total town population in the basin for the study period was 398 out of a total town population of 5,932 (table 6). No public water suppliers are in the part of Exeter in the basin. Outside the basin, the Ladd School operated as a minor public water supplier and small facility that treated their wastewater for 5 months (from January through May of 1995). The facility is currently (2004) owned by the Rhode Island Economic Development Corporation (RIEDC) and is undeveloped.

The town of Foster is in western Rhode Island (fig. 1). The total land area is $51.94 \mathrm{mi}^{2}$, of which $31.85 \mathrm{mi}^{2}$ is in the Pawtuxet River Basin. The total town population in the basin for the study period was 2,727 out of a total town population of 4,410 (table 6). Foster has no major public water suppliers; likewise, the town has no local wastewater collection. Three minor public water suppliers, however, serve small populations in the town.

The town of Glocester is in western Rhode Island (fig. 1). The total land area is $56.83 \mathrm{mi}^{2}$, of which $16.39 \mathrm{mi}^{2}$ is in the Pawtuxet River Basin. The total town population in the basin for the study period was 2,815 out of a total town population of 9,280 (table 6). Glocester has no public water supply in the basin; likewise, the town has no local wastewater collection.

The town of Johnston is in central Rhode Island (fig. 1). The total land area is $24.33 \mathrm{mi}^{2}$, of which $16.54 \mathrm{mi}^{2}$ is in the Pawtuxet River Basin. The total town population in the basin for the study period was 13,985 out of a total town population of 26,433 (table 6). During the study period, the Cranston Water District served the area of the town area west of Interstate 295 until 1997. From 1997 to the present (2004), the area has been served by the Johnston Water District. ProvWater serves the area in Johnston east of Interstate 295; this area is part of ProvWater's retail service area. No minor public water suppliers are in the part of Johnston that is in the basin. Johnston has no local wastewater collection; however, the town wastewater is collected and processed by a regional facility, the Narragansett Bay Commission facility at Fields Point in Providence. This WWTF is along Narragansett Bay and discharges to the bay.

The city of Providence is in central Rhode Island (fig. 1). The total land area is $18.78 \mathrm{mi}^{2}$, of which $2.952 \mathrm{mi}^{2}$ is in the Pawtuxet River Basin. The total city population in the basin for the study period was 23,957 out of a total city of 151,151 (table 6). ProvWater serves the city. No minor public water suppliers are in the part of Providence that is in the basin. City wastewater is collected and processed by the NBC facility at Fields Point in Providence.

The town of Scituate is in central Rhode Island (fig. 1). The total land area is $54.81 \mathrm{mi}^{2}$, of which $54.79 \mathrm{mi}^{2}$ is in the Pawtuxet River Basin. The total town population in the basin for the study period was 10,006 out of a total town population of 10,012 (table 6). The Kent County Water Authority serves the southeastern corner of the town, and the Johnston Water District serves the northeastern part of the town. Three minor public water suppliers serve small populations in the town. The West Warwick Regional WWTF collects and processes wastewater for the southeast corner of Scituate.

The town of Smithfield is in north central Rhode Island (fig. 1). The total land area is $27.61 \mathrm{mi}^{2}$, of which $0.032 \mathrm{mi}^{2}$ is in the Pawtuxet River Basin. The total town population in the basin for the study period was 90 out of a total town population of 18,906 (table 6). The part of Smithfield that is in the basin has no public water supply or wastewater collection.

The city of Warwick is in central Rhode Island (fig. 1). The total land area is $35.02 \mathrm{mi}^{2}$, of which $7.183 \mathrm{mi}^{2}$ is in the Pawtuxet River Basin. The total town population in the basin for the study period was 17,081 out of a total town population of 84,038 (table 6). The major public water supplies for the city are operated and maintained by the Warwick Water Department and the Kent County Water Authority. Warwick purchases water from ProvWater. The Kent County Water Authority, in addition to obtaining water from its own withdrawal wells, purchases water wholesale from ProvWater and the Warwick Water Department. No minor public water suppliers are in the part of Warwick that is in the Pawtuxet River Basin. The Warwick WWTF and the West Warwick Regional WWTF collect and process wastewater for the city.

The town of West Greenwich is in central Rhode Island (fig. 1). The total land area is $51.22 \mathrm{mi}^{2}$, of which $23.10 \mathrm{mi}^{2}$ is in the Pawtuxet River Basin. The total town population in the basin for the study period was 2,330 out of a total town population of 3,956 (table 6). The Kent County Water Authority serves the part of West Greenwich that is in the basin. One minor water supplier serves a small population in the basin. A small area of West Greenwich in the basin is served by the West Warwick Regional WWTF. 
The city of West Warwick is in central Rhode Island (fig. 1). The total land area is $8.091 \mathrm{mi}^{2}$, of which $5.943 \mathrm{mi}^{2}$ is in the Pawtuxet River Basin. The total town population in the basin for the study period was 21,925 out of a total town population of 29,034 (table 6). The Kent County Water Authority serves West Warwick. City wastewater is collected and processed by the West Warwick Regional WWTF.

\section{The Quinebaug River Basin}

The Quinebaug River Basin is in western Rhode Island, eastern Connecticut, and south central Massachusetts (fig. 9). The total land area in the basin is about $743 \mathrm{mi}^{2}$ (Thomas and others, 1966), which includes about $60.97 \mathrm{mi}^{2}$ in Rhode Island, about $433 \mathrm{mi}^{2}$ in Connecticut, and about $249 \mathrm{mi}^{2}$ in Massachusetts (Simcox, 1992). Four major tributaries enter the Quinebaug River in Connecticut, including the French River from the north, the Fivemile River from the northeast, the Moosup River from the east, and the Pachaug River from the southeast (fig. 9). Only the part of the basin in Rhode Island, however, was included in this analysis.

Six Rhode Island towns are partially within the basin. In 1990 , the basin population was about 4,483 , and the estimated population during the study period was 4,541 (table 2 ). The Quinebaug River Basin is mostly hilly, with higher altitudes in the northwest. No defined principal aquifers are in the study area; however, it does include areas of stratified sand and gravel deposits (fig. 5). On the basis of the surface-water-drainage boundaries, about 27.1 percent of the area of the surficial deposits in the Quinebaug River Basin is stratified sand and gravel deposits.

The USGS subbasin boundaries delineated for this study area differ from the cataloging units defined by the WBD (fig. 6). Naming conventions also differ between the Quinebaug River Basin study and the 10-digit and 12-digit cataloging units. The study area was defined by the USGS 8-digit HUC because use of the 10-digit cataloging units resulted in withdrawals and water use less than $0.001 \mathrm{Mgal} / \mathrm{d}$ when estimated by town, and because there are no defined ground-water aquifers in the basin. Comparisons of land-area and naming conventions between the Quinebaug River Basin and the WBD cataloging units are presented in table 5 .

The town of Burrillville is in northwestern Rhode Island (fig. 1). The total land area is $56.96 \mathrm{mi}^{2}$, of which $8.595 \mathrm{mi}^{2}$ is in the Quinebaug River Basin. The total town population in the basin for the study period was 514 out of a total town population of 15,910 . For the town of Coventry, the land area in the basin is $20.30 \mathrm{mi}^{2}$, and the estimated town population in the basin was 1,569 (table 6). One minor public water supplier serves a small population in the part of the town in the basin. The land area in Exeter in the basin is $1.432 \mathrm{mi}^{2}$, and the estimated town population in the basin was 81. The land area in Foster in the basin is $20.09 \mathrm{mi}^{2}$, and the estimated town population in the basin was 1,684. The land area in Glocester in the basin is $9.703 \mathrm{mi}^{2}$, and the estimated town population in the basin was 647 . The land area in West Greenwich in the basin is $0.853 \mathrm{mi}^{2}$, and the estimated town population in the basin was 46 (table 6). The Quinebaug River Basin had no local or regional wastewatercollection service areas during the study period.

\section{Estimated Water Use}

Water-use data for the study period for the Pawtuxet and Quinebaug River Basins were organized by using NEWUDS. Components of water use include water withdrawals, publicsupply distributions, nonaccount use, water use by category, consumptive water use, wastewater-system collections, and return flow (fig. 3). Withdrawal data were categorized as either self- or public supply from surface and ground water. Conveyance losses are an example of nonaccount water use (which is unmetered) in public-supply systems, and include leaks, system flushing, and fire-hydrant uses. The nonaccount water use for a public-supply system is calculated as the difference between the total distribution and the distributions received for all of the water-use categories in the system. Water-use categories in this report are domestic, commercial, industrial, and agricultural for public-supply and self-supply users. The public-supply withdrawals were from surface and ground water, whereas minor public-supply and self-supply domestic, industrial, and commercial withdrawals were only from ground water. Consumptive water use is water removed from the environment through uses by humans, livestock, production, or evapotranspiration. Wastewater from a local or a regional public wastewater system is returned to a surface-water body. Return flow to ground water or surface water includes wastewater disposed from site-specific discharges, permitted discharges, and aggregate discharges. Water withdrawals, water use, consumptive use, and return flow were calculated for each subbasin by town for the calendar years during the study period. Because the Quinebaug River Basin has no major public water suppliers, wastewater collection, and interbasin transfers, the sections of the report on these topics pertain only to the Pawtuxet River Basin.

\section{New England Water-Use Data System}

The NEWUDS database was used as a tool to track the water withdrawn in the Pawtuxet and Quinebaug River Basins. The database was queried to obtain the average water use for the study period, and the results are presented in the tables of this report. The data entered into NEWUDS consist of site-specific and aggregate water withdrawals, uses, and discharges in the two basins. When available, monthly, quarterly, and (or) yearly metered (or reported) data were entered as reported from the original source, and were converted to common units (Mgal/d) for comparison into NEWUDS. Unmetered water withdrawals, uses, and discharges were calculated by methods used to estimate water use by category. For quality-assurance purposes, NEWUDS allows the data compiler to indicate the original data 


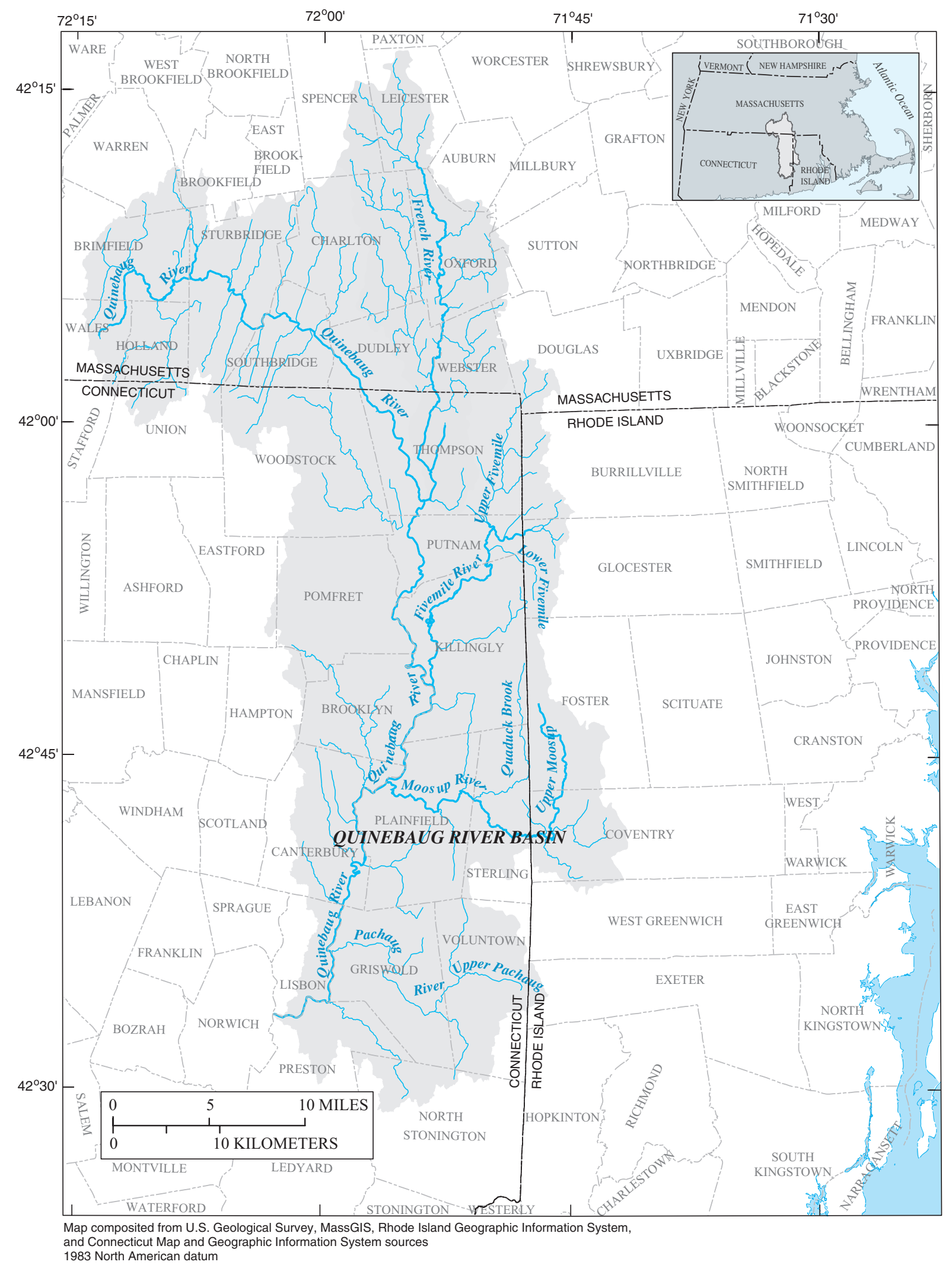

Figure 9. The Quinebaug River Basin in western Rhode Island, northeastern Connecticut, and south-central Massachusetts. 
source, rate units, and the method of reporting the water-use rate. Documentation describing database development and how to use the database are presented in Tessler (2002) and Horn (2003), respectively.

\section{Public Water Supply and Interbasin Transfers}

Five major public suppliers served the domestic, commercial, industrial, and agricultural sectors in the Pawtuxet River Basin during the study period (table 7, fig. 10): Cranston Water District, Johnston Water District, Kent County Water Authority, Providence Water Supply Board, and Warwick Water Department. Ten minor water suppliers, such as nursing homes, condominium associations, and mobile home parks, served small public populations; nine minor suppliers were in the Pawtuxet River Basin and one was in the Quinebaug River Basin (table 8). The total public-supply withdrawals by subbasin and town are summarized in table 9.

Potable interbasin transfers are water that is conveyed from public water suppliers across hydrologic divides between basins and subbasins. The water is an import, or a gain to the Pawtuxet River Basin, if the water is withdrawn in another basin or subbasin and used in the Pawtuxet River Basin. The water is an export, or a loss to the basin, if the water is withdrawn in the basin but used elsewhere in another basin or subbasin.

Table 7. Withdrawals by major public water-supply districts in and outside the subbasins of the Pawtuxet River Basin, central Rhode Island, 1995-99.

[The Cranston and Johnston Water Districts and the Warwick Water Department do not withdraw water; they only purchase water. Reference number: Identifier used in figure 5. Aquifer type: SG, sand and gravel. HAP, Hunt-Annaquatucket-Pettaquamscutt; Mgal/d, million gallons per day; --, not applicable]

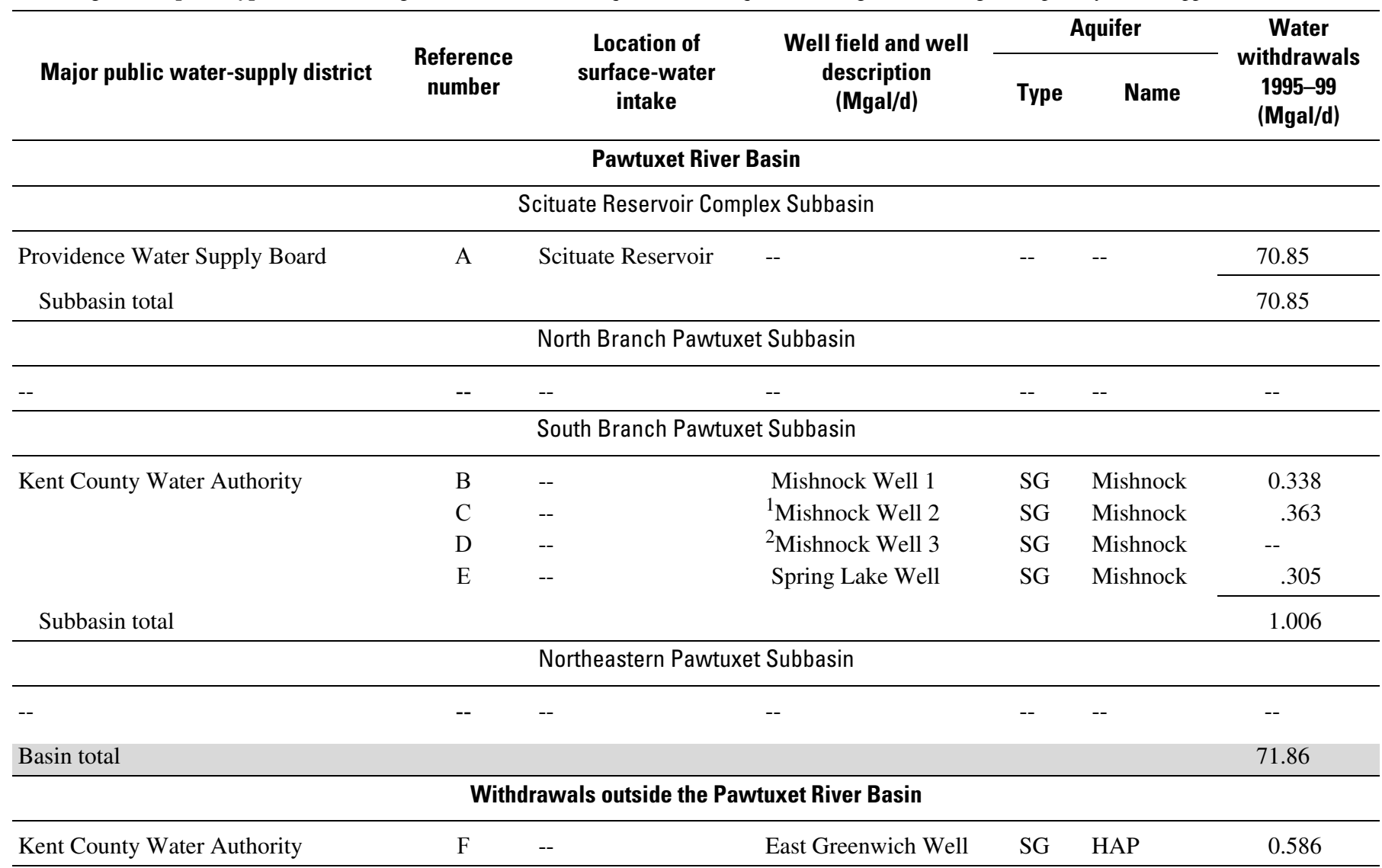

\footnotetext{
${ }^{1}$ Mishnock well 2 was discontinued after October 1999.
}

${ }^{2}$ Mishnock well 3 was drilled near the site of discontinued Mishnock well 2. Withdrawals started in March 2000 and continue to the present (2004). 


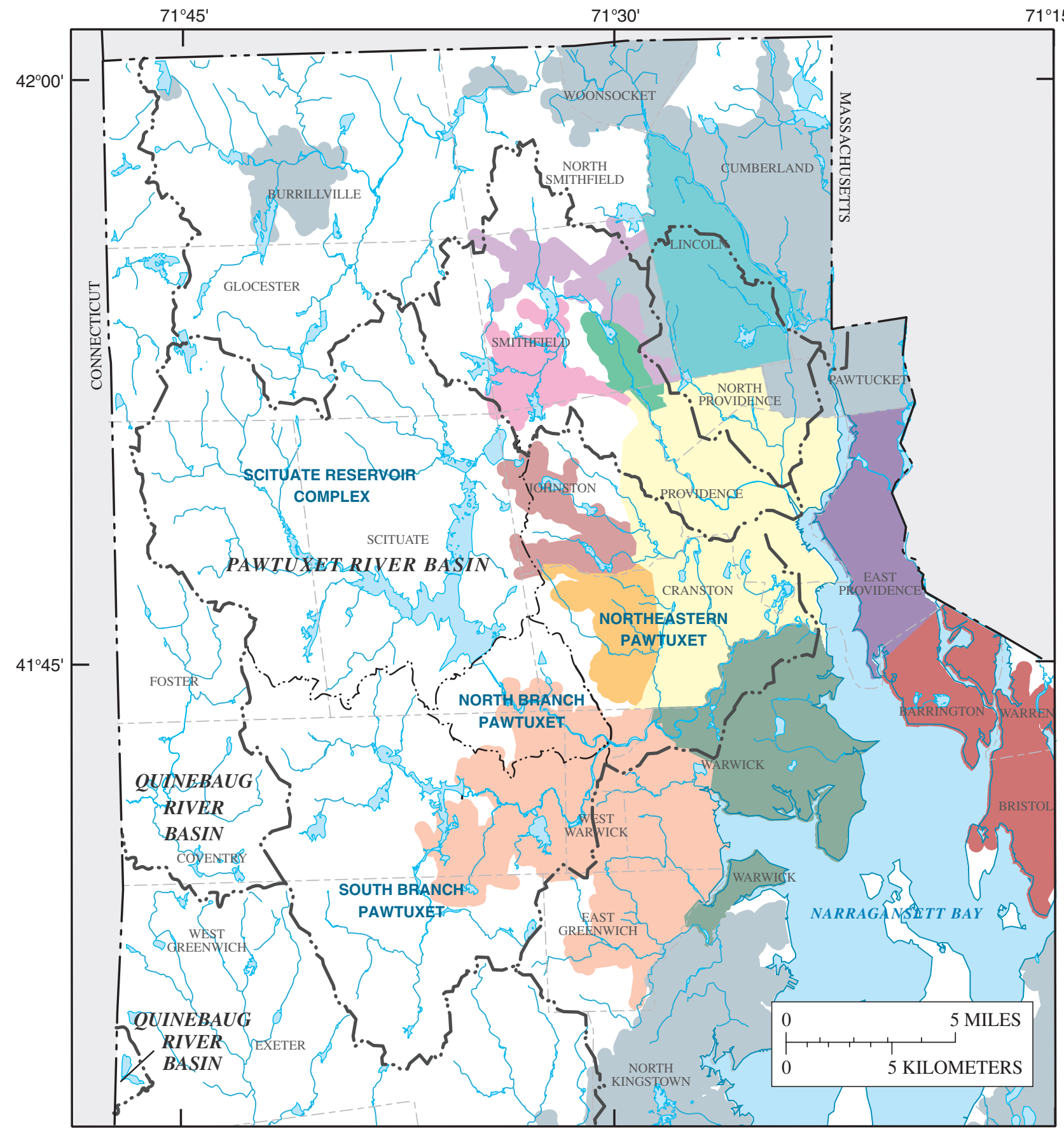

Base from U.S. Geological Survey and Rhode Island Geographic Information System digital data (1995b), 1:24,000, Lambert conformal conic projection. 1983 North American datum

\section{EXPLANATION}

MAJOR PUBLIC WATER-SUPPLY DISTRICTS-Districts in Pawtuxet study area are in bold type. See figures 11-14 for schematic diagrams of water distribution
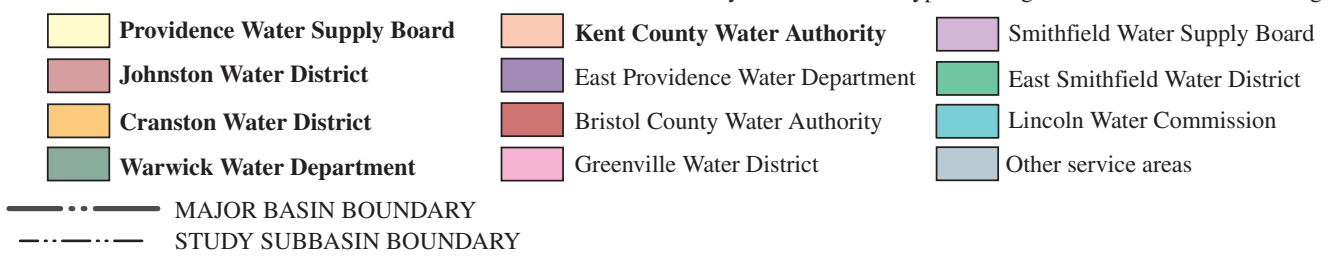

Figure 10. Public water-supply districts associated with the Pawtuxet River Basin and in the northern Narragansett Bay area, Rhode Island. 


\section{Estimated Water Use and Availability in the Pawtuxet and Quinebaug River Basins, Rhode Island, 1995-99}

Table 8. Minor public water suppliers by subbasin in the Pawtuxet River Basin, central Rhode Island, and in the Quinebaug River Basin, western Rhode Island, 1995-99.

[Shaded areas are basin totals. Minor public water supplier: Coefficient used for minor supplier population is $67 \mathrm{gal} / \mathrm{d} / \mathrm{person}$. Reference number: Identifier used in figure 5. Aquifer type: BD, bedrock; SG, sand and gravel. gal/d/person, gallons per day per person; Mgal/d, million gallons per day; --, not applicable]

\begin{tabular}{|c|c|c|c|c|c|}
\hline \multirow[b]{2}{*}{ Minor public water supplier } & \multirow[b]{2}{*}{$\begin{array}{c}\text { Reference } \\
\text { number }\end{array}$} & \multirow[b]{2}{*}{ Town } & \multirow[b]{2}{*}{ Aquifer type } & \multicolumn{2}{|c|}{ Estimated 1995-99 } \\
\hline & & & & Population & $\begin{array}{c}\text { Water } \\
\text { withdrawals } \\
\text { and use } \\
\text { (Mgal/d) }\end{array}$ \\
\hline \multicolumn{6}{|c|}{ Pawtuxet River Basin } \\
\hline \multicolumn{6}{|c|}{ Scituate Reservoir Complex Subbasin } \\
\hline Abbey Lane Community Association & 1 & Foster & $\mathrm{BD}$ & 46 & 0.003 \\
\hline Nancy Ann Nursing Home, Inc. & 2 & Foster & $\mathrm{BD}$ & 20 & .001 \\
\hline Hemlock Village & 3 & Foster & $\mathrm{BD}$ & 34 & .002 \\
\hline Oak Crest Manor, Inc. & 4 & Scituate & $\mathrm{BD}$ & 46 & .003 \\
\hline Scituate Housing for the Elderly/Rockland Oaks & 5 & Scituate & $\mathrm{BD}$ & 26 & .002 \\
\hline Scituate Commons & 6 & Scituate & $\mathrm{BD}$ & 35 & .002 \\
\hline Subbasin total & & & & 207 & 0.013 \\
\hline \multicolumn{6}{|c|}{ North Branch Pawtuxet Subbasin } \\
\hline-- & -- & -- & -- & -- & -- \\
\hline \multicolumn{6}{|c|}{ South Branch Pawtuxet Subbasin } \\
\hline Blueberry Heights Mobile Park & 7 & West Greenwich & $\mathrm{BD}$ & 50 & .003 \\
\hline Alpine Nursing Home & 8 & Coventry & $\mathrm{BD}$ & 29 & .002 \\
\hline Woodland Homeowners Association & 9 & Coventry & SG & 120 & .008 \\
\hline Subbasin total & & & & 199 & 0.013 \\
\hline \multicolumn{6}{|c|}{ Northeastern Pawtuxet Subbasin } \\
\hline $\begin{array}{ll}- \\
\end{array}$ & -- & -- & -- & -- & -- \\
\hline Basin total & & & & 406 & 0.026 \\
\hline \multicolumn{6}{|c|}{ Quinebaug River Basin } \\
\hline Woodpecker Hill Nursing Home & 10 & Coventry & $\mathrm{BD}$ & 40 & 0.003 \\
\hline Basin total & & & & 40 & 0.003 \\
\hline
\end{tabular}


Table 9. Ground-water and surface-water withdrawals by town and subbasin in the Pawtuxet River Basin, central Rhode Island, and in the Quinebaug River Basin, western Rhode Island, 1995-99.

[Shaded areas are basin totals. Withdrawals are from ground-water wells and surface-water reservoirs. For agricultural use, irrigation water withdrawals are assumed to be 81 percent from surface water (ponds and rivers) and 13 percent from ground water (wells). Livestock water withdrawals are assumed to be 9 percent from surface water and 82 percent from ground water. The remaining 6 percent for irrigation and 9 percent for livestock are assumed to be from public supply. All towns are in Rhode Island unless otherwise noted. Mgal/d, million gallons per day; <0.001, value not included in totals; --, not applicable]

\begin{tabular}{|c|c|c|c|c|c|c|}
\hline \multirow{2}{*}{ Towns } & \multirow{2}{*}{$\begin{array}{c}\text { Public-supply } \\
\text { withdrawals } \\
\text { (Mgal/d) }\end{array}$} & \multicolumn{4}{|c|}{ Self-supply withdrawals (Mgal/d) } & \multirow{2}{*}{$\begin{array}{c}\text { Total } \\
(\text { Mgal/d) }\end{array}$} \\
\hline & & Domestic & Commercial & Industrial & Agricultural & \\
\hline \multicolumn{7}{|c|}{ Pawtuxet River Basin } \\
\hline \multicolumn{7}{|c|}{ Scituate Reservoir Complex Subbasin } \\
\hline Cranston & -- & 0.003 & -- & -- & 0.002 & 0.005 \\
\hline Johnston & -- & .038 & -- & -- & .001 & .039 \\
\hline Scituate & 70.86 & .538 & .008 & .012 & .007 & 71.43 \\
\hline Smithfield & -- & .006 & -- & -- & $<.001$ & .006 \\
\hline Subbasin total & 70.87 & 0.956 & 0.016 & 0.014 & 0.015 & 71.87 \\
\hline \multicolumn{7}{|c|}{ North Branch Pawtuxet Subbasin } \\
\hline West Warwick & -- & .002 & -- & -- & -- & .002 \\
\hline Subbasin total & -- & 0.118 & $<0.001$ & 0.009 & 0.011 & 0.138 \\
\hline \multicolumn{7}{|c|}{ South Branch Pawtuxet Subbasin } \\
\hline Coventry & 1.016 & 0.430 & 0.004 & 0.017 & 0.022 & 1.489 \\
\hline East Greenwich & -- & .001 & -- & -- & -- & .001 \\
\hline Exeter & -- & .028 & .001 & -- & .002 & .031 \\
\hline Foster & -- & .015 & -- & -- & .003 & .018 \\
\hline Scituate & -- & .020 & -- & -- & .001 & .021 \\
\hline Warwick & -- & -- & -- & -- & -- & -- \\
\hline West Greenwich & .003 & .113 & .001 & .065 & $<.001$ & .182 \\
\hline Warwick & -- & $<.001$ & -- & -- & -- & $<.001$ \\
\hline West Warwick & -- & .010 & -- & -- & -- & .010 \\
\hline Subbasin total & -- & 0.229 & 0.042 & 0.015 & 0.020 & 0.306 \\
\hline Basin total & 71.89 & 1.915 & 0.064 & 0.120 & 0.074 & 74.06 \\
\hline \multicolumn{7}{|c|}{ Quinebaug River Basin } \\
\hline Burrillville & -- & 0.036 & -- & -- & $<0.001$ & 0.036 \\
\hline Coventry & 0.003 & .109 & 0.002 & 0.004 & .007 & .125 \\
\hline Exeter & -- & .006 & -- & -- & -- & .006 \\
\hline Foster & -- & .120 & $<.001$ & -- & .024 & .144 \\
\hline Glocester & -- & .045 & .003 & $<.001$ & .001 & .049 \\
\hline West Greenwich & -- & .003 & -- & -- & -- & .003 \\
\hline Basin total & 0.003 & 0.319 & 0.005 & 0.004 & 0.032 & 0.363 \\
\hline
\end{tabular}


The Cranston Water District purchased water from ProvWater and maintained the six Johnston Water District interconnections until 1997. At this time, Johnston started to maintain the interconnections with ProvWater, and the Cranston Water District became part of ProvWater's retail-service area. During the transition, records of the historical purchases that the Cranston Water District maintained were destroyed by fire, so they were unavailable for this study.

The Johnston Water District purchases water through six interconnections with ProvWater (fig. 11). Monthly data for each of the six interconnections were available from January 1998 through December 1999. The total of the Johnston wholesale purchases for each month was available from ProvWater for calendar year 1997, but the monthly data were not available for each individual interconnection. Johnston's monthly wholesale purchases for 1995 and 1996 were not available and were estimated on the basis of the 1998 and 1999 data (Peter LePage, Providence Water Supply Board, written commun., 2002).

The Kent County Water Authority system includes Mishnock wells 1, 2, and 3, and Spring Lake well, all of which withdraw from the Mishnock aquifer in the South Branch Pawtuxet subbasin (fig. 12). Mishnock well 3 was not in operation during the study period. An average of $1.006 \mathrm{Mgal} / \mathrm{d}$ was withdrawn during the study period from the Mishnock aquifer. The Kent County Water Authority withdrawal well in East Greenwich withdrew $0.586 \mathrm{Mgal} / \mathrm{d}$ from the Hunt-Annaquatucket-Pettaquamscutt aquifer (fig. 5) in the West Narragansett Bay Basin (fig. 12). To supplement the system, the Kent County Water Authority purchased 6.752 Mgal/d from ProvWater and 1.537 $\mathrm{Mgal} / \mathrm{d}$ from the Warwick Water Department (fig. 12). The Kent County Water Authority sold 0.221 Mgal/d to the Warwick Water Department to supply Potowomut, a small section in Warwick that is east of East Greenwich.

Water sources for withdrawals and purchases by the Kent County Water Authority differed during the study period. To determine what percentage of withdrawals and purchases occurred during each month of the summer, the well withdrawals for June, July, August, and September were compared to the total of the withdrawals and purchases for June, July, August, and September, respectively (table 10). Likewise, the percentages of wholesale purchases from each of the interconnections for each month were compared to the total water withdrawn and purchased June, July, August, and September, respectively (table 10). The Kent County Water Authority withdrawals ranged from 16 percent in June and July to 18 percent in September of the total water withdrawn and purchased for the system. From the total water withdrawn and purchased for the Kent County Water Authority system, withdrawals from the Mishnock aquifer in the Pawtuxet River Basin ranged from 8.6 percent in July to 11 percent in September; withdrawals from the East Greenwich well ranged from 6.7 percent in September to 8.2 percent in August; wholesale water purchases from the Clinton interconnection ranged from 54 percent in July to 61 percent in September; wholesale water purchases from the Oaklawn interconnection ranged from 1.8 percent in September to 2.8 percent in July; and wholesale water purchases from the Bald
Hill interconnection ranged from 19 percent in September to 26 percent in July.

In 2000, ProvWater supplied 70.39 percent of the publicsupply surface-water withdrawals and 60.40 percent of all public-supply water withdrawals in Rhode Island. The average rate of water withdrawal from the Scituate Reservoir to the J.P. Holton Water Purification Plant for the study period was 70.85 $\mathrm{Mgal} / \mathrm{d}$ in the Scituate Reservoir Complex subbasin. ProvWater collects data on the rate of water movement within the subbasin; 35.25 Mgal/d flowed over the spillway and $11.92 \mathrm{Mgal} / \mathrm{d}$ flowed through the gatehouse during the study period (fig. 13a). ProvWater withdrawals conveyed to the purification plant accounted for 98.58 percent of the total withdrawals in the Scituate Reservoir Complex subbasin and 95.67 percent of the total withdrawals in the Pawtuxet River Basin during the study period. Retail distribution was more than 58 percent of the total regional distribution from the purification plant to cities inside and outside the study area; further analysis and estimation was completed to assess the movement of this water within and out of the Pawtuxet River Basin (fig. 13b). It was estimated that most of the retail sales, about 46 percent, were for domestic water users, and about 36 percent of this water was used in the Pawtuxet River Basin.

During the summer when precipitation is limited, water use tends to increase. For this reason and because ProvWater supplies over 60 percent of the Rhode Island population, average water withdrawal and distribution rates for the system for June, July, August, and September were calculated (table 11). The regional distribution for the system ranged from 71.81 $\mathrm{Mgal} / \mathrm{d}$ in September to $91.52 \mathrm{Mgal} / \mathrm{d}$ in July. Retail distribution ranged from $40.45 \mathrm{Mgal} / \mathrm{d}$ in September to $49.23 \mathrm{Mgal} / \mathrm{d}$ in July. Wholesale purchases by other public-supply districts varied from year to year because of water restrictions were different each year and because the sizes of the public-supply districts changed. Also, wholesale purchases made by some publicsupply districts from ProvWater varied from one year to the next. These districts included the Lincoln Water Commission, Kent Count Water Authority, and the Bristol County Water Authority. Purchases from ProvWater generally were less in September and more in July. The three highest wholesale purchases each accounted for more than 8 percent of the regional distribution.

The Warwick Water Department had no withdrawals during the study period; instead, it purchased 9.649 Mgal/d from ProvWater and $0.221 \mathrm{Mgal} / \mathrm{d}$ from the Kent County Water Authority (fig. 14). The Warwick Water Department also sold $1.537 \mathrm{Mgal} / \mathrm{d}$ to the Kent County Water Authority; of this amount, about $0.054 \mathrm{Mgal} / \mathrm{d}$ was nonaccount water use.

Nine minor public suppliers served the Pawtuxet River Basin (table 8). Limited data were available on minor publicsupply withdrawals from these users; therefore, water withdrawals and use were estimated by applying the water-use coefficient for domestic users (67 gal/d/person) on public supply (Korzendorfer and Horn, 1995). The total of the estimated water withdrawn by minor suppliers was $0.026 \mathrm{Mgal} / \mathrm{d}$. There were no 


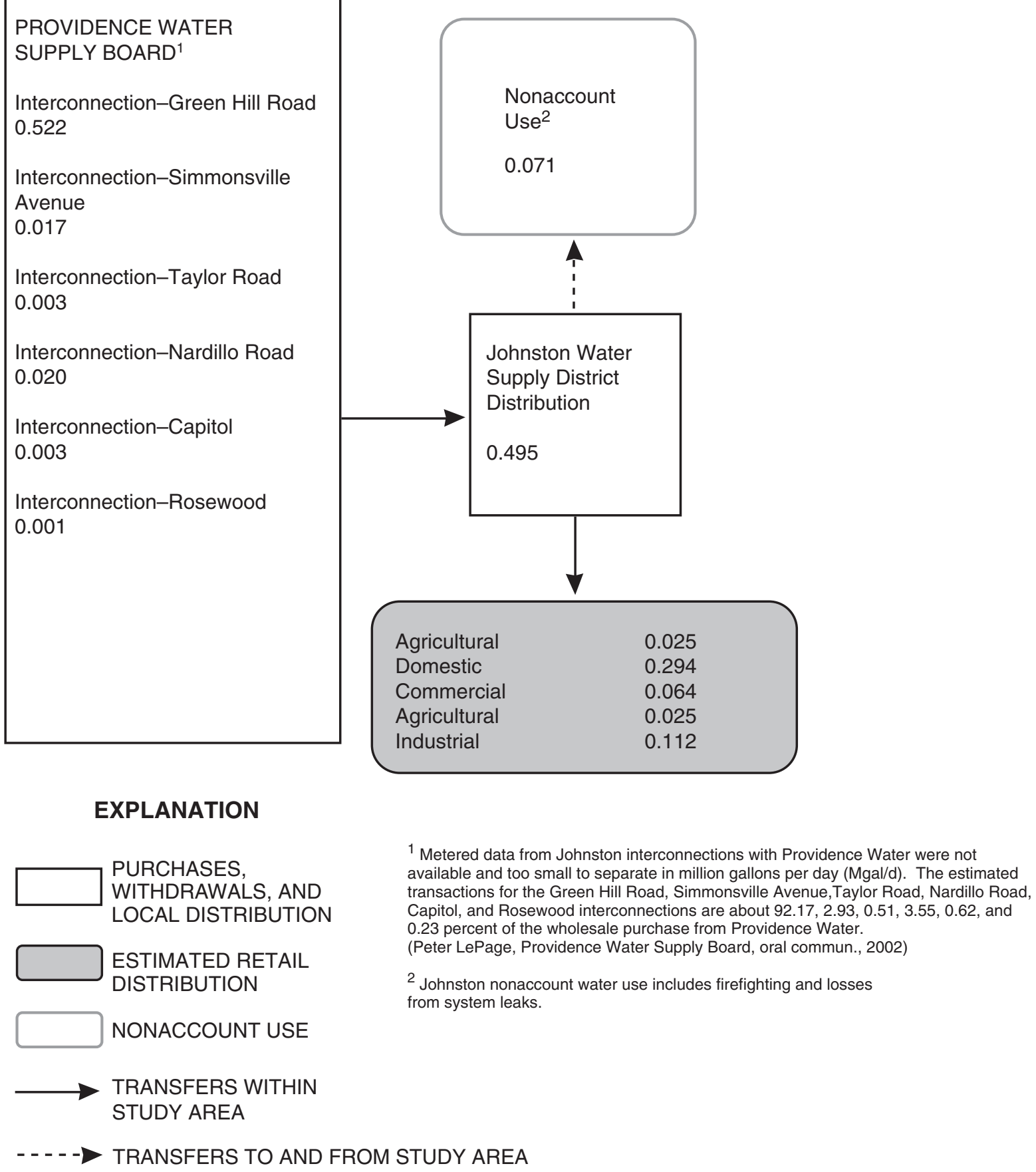

Figure 11. Johnston Water District interconnections, purchases, distribution, exports, and estimated water uses in the Pawtuxet River Basin, central Rhode Island, 1995-99. All rates in Mgal/d, million gallons per day. 


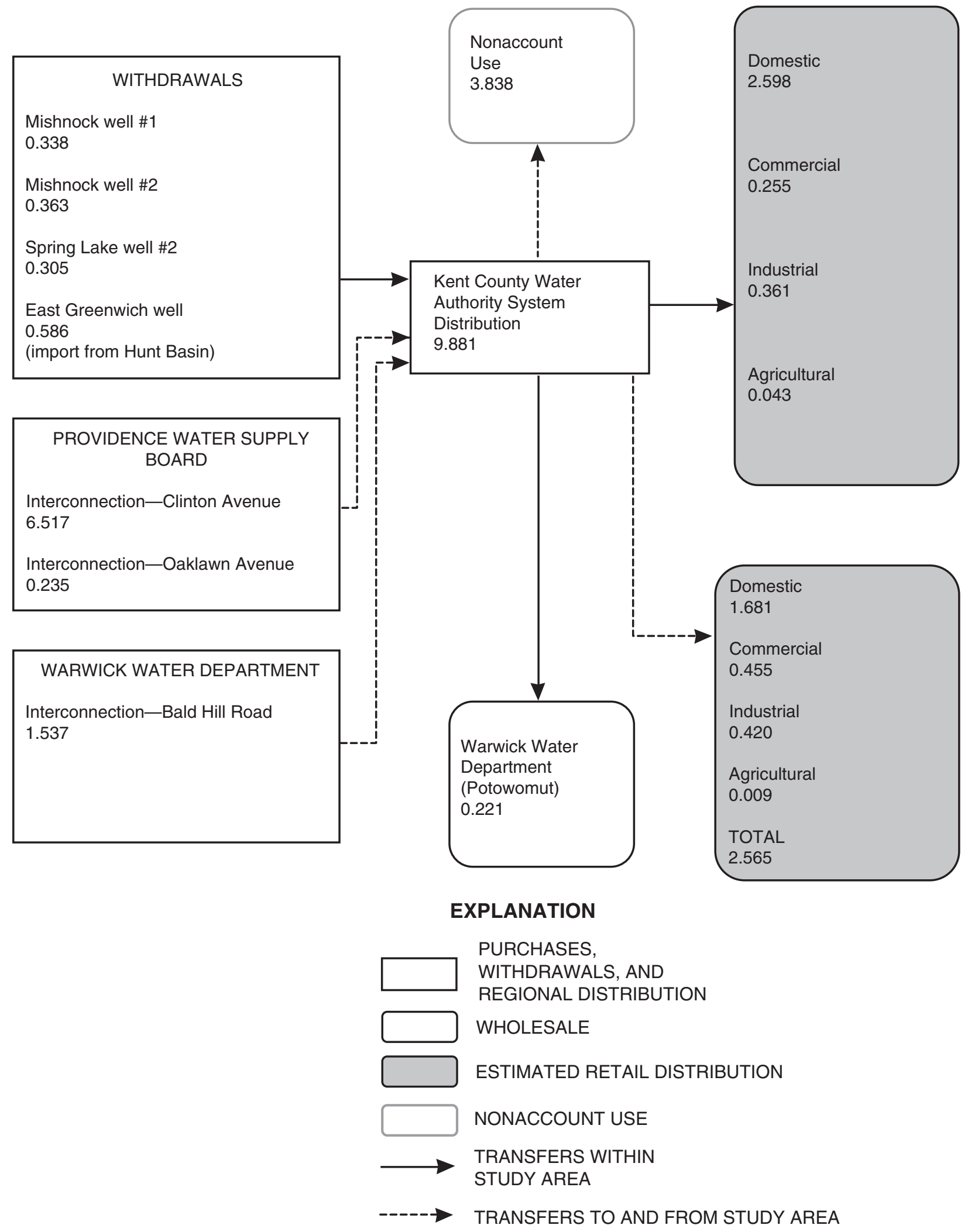

Figure 12. Kent County Water Authority withdrawals, interconnections, purchases, distribution, exports, and estimated water uses, central Rhode Island, 1995-99. All rates in Mgal/d, million gallons per day; KCWA, Kent County Water Authority. 
Table 10. Average withdrawals and purchases for the Kent County Water Authority for June, July, August, and September, 1995-99.

[ProvWater, Providence Water Supply Board; Mgal/d, million gallons per day; --, not applicable]

Kent County Water Authority withdrawals and purchases

\begin{tabular}{|c|c|c|c|c|c|}
\hline \multirow{2}{*}{$\begin{array}{l}\text { Transaction, resource name, } \\
\text { site type }\end{array}$} & \multirow{2}{*}{ Conveyance action } & \multicolumn{4}{|c|}{ Transaction rate (Mgal/d) } \\
\hline & & June & July & August & September \\
\hline $\begin{array}{l}\text { Withdrawal from Mishnock well 1, Mishnock } \\
\text { aquifer, withdrawal well }\end{array}$ & $\begin{array}{l}\text { From withdrawal well to } \\
\text { regional distribution }\end{array}$ & 0.234 & 0.268 & 0.370 & 0.274 \\
\hline $\begin{array}{l}\text { Withdrawal from Mishnock well 2, Mishnock } \\
\text { aquifer, withdrawal well }\end{array}$ & $\begin{array}{l}\text { From withdrawal well to } \\
\text { regional distribution }\end{array}$ & .528 & .546 & .436 & .524 \\
\hline $\begin{array}{l}\text { Withdrawal from Spring Lake well, Mishnock } \\
\text { aquifer, withdrawal well }\end{array}$ & $\begin{array}{l}\text { From withdrawal well to } \\
\text { regional distribution }\end{array}$ & .412 & .424 & .376 & .352 \\
\hline $\begin{array}{l}\text { Withdrawal from East Greenwich well, Hunt } \\
\text { aquifer, regional distribution system }\end{array}$ & $\begin{array}{l}\text { From withdrawal well to } \\
\text { regional distribution }\end{array}$ & .877 & 1.135 & 1.045 & .701 \\
\hline $\begin{array}{l}\text { Wholesale purchase from } \\
\text { ProvWater at Clinton, --, } \\
\text { regional distribution system }\end{array}$ & $\begin{array}{l}\text { From regional } \\
\text { distribution to regional } \\
\text { distribution }\end{array}$ & 7.479 & 7.846 & 7.215 & 6.453 \\
\hline $\begin{array}{l}\text { Wholesale purchase from } \\
\text { ProvWater at Oaklawn, --, } \\
\text { regional distribution system }\end{array}$ & $\begin{array}{l}\text { From regional } \\
\text { distribution to regional } \\
\text { distribution }\end{array}$ & .301 & .403 & .297 & .184 \\
\hline $\begin{array}{l}\text { Wholesale purchase from Warwick Water } \\
\text { Department at Bald Hill, --, local distribution } \\
\text { system }\end{array}$ & $\begin{array}{l}\text { From local distribution to } \\
\text { regional distribution }\end{array}$ & 3.000 & 3.777 & 3.034 & 2.016 \\
\hline Kent County Water Authority totals & & 12.83 & 14.40 & 12.77 & 10.50 \\
\hline
\end{tabular}

minor public-supply withdrawals in the North Branch Pawtuxet and Northeastern Pawtuxet subbasins, and the minor publicsupply withdrawals in the Scituate Reservoir Complex and South Branch Pawtuxet subbasins were each 0.013 Mgal/d. Estimated water withdrawals for the individual minor suppliers ranged from $0.001 \mathrm{Mgal} / \mathrm{d}$ to $0.008 \mathrm{Mgal} / \mathrm{d}$. One minor public supplier in the Quinebaug River Basin withdrew an estimated $0.003 \mathrm{Mgal} / \mathrm{d}$.

\section{Domestic Water Use}

Domestic water use is water used by residential populations served by public supplies or by private wells. To calculate the water use for this category, population estimates in Rhode Island were multiplied by the water-use coefficients $71 \mathrm{gal} / \mathrm{d} /$ person for self-supply domestic water use and $67 \mathrm{gal} / \mathrm{d} /$ person for public-supply domestic water use. These coefficients were based on the 1990 national water-use compilation (Korzendorfer and Horn, 1995).

\section{Public-Supply Use in the Pawtuxet and Quinebaug River Basins}

Because water suppliers provide information on populations served within towns rather than within subbasins, census coverages available through RIGIS were used to estimate subbasin populations on public supply. The 1990 census blocks, which include the domestic populations on private wells, were merged with the subbasin coverages. The 1990 self-supply population was subtracted from the total population to obtain the public-supply population for the part of each town in each subbasin. The 1990 populations on public and self-supply were divided by the total population for the part of each town within each subbasin to determine the percentages of public- and selfsupply populations within each subbasin. This method was repeated for the 1990 populations on public-wastewater collection and wastewater return flow for domestic users, also known as septic systems. The 1995-99 population on self-supply for each subbasin was estimated by multiplying the 1990 population by the ratio of growth or decline within each subbasin from 1995 through 1999 (table 2). The percentages of public- and self-supply populations, assumed to be the same for the 1995-99 study period as for 1990, were applied to the 1995-99 populations to determine the 1995-99 populations on self-disposal and on public-wastewater collection (table 2). The 1995-99 populations on public-wastewater collection and selfdisposal of wastewater were then calculated by the same subtraction procedure as above. Because limited withdrawal data were available for the 13 minor public suppliers in the basin, the water-use coefficient was applied to the populations served by each supplier (Korzendorfer and Horn, 1995). 


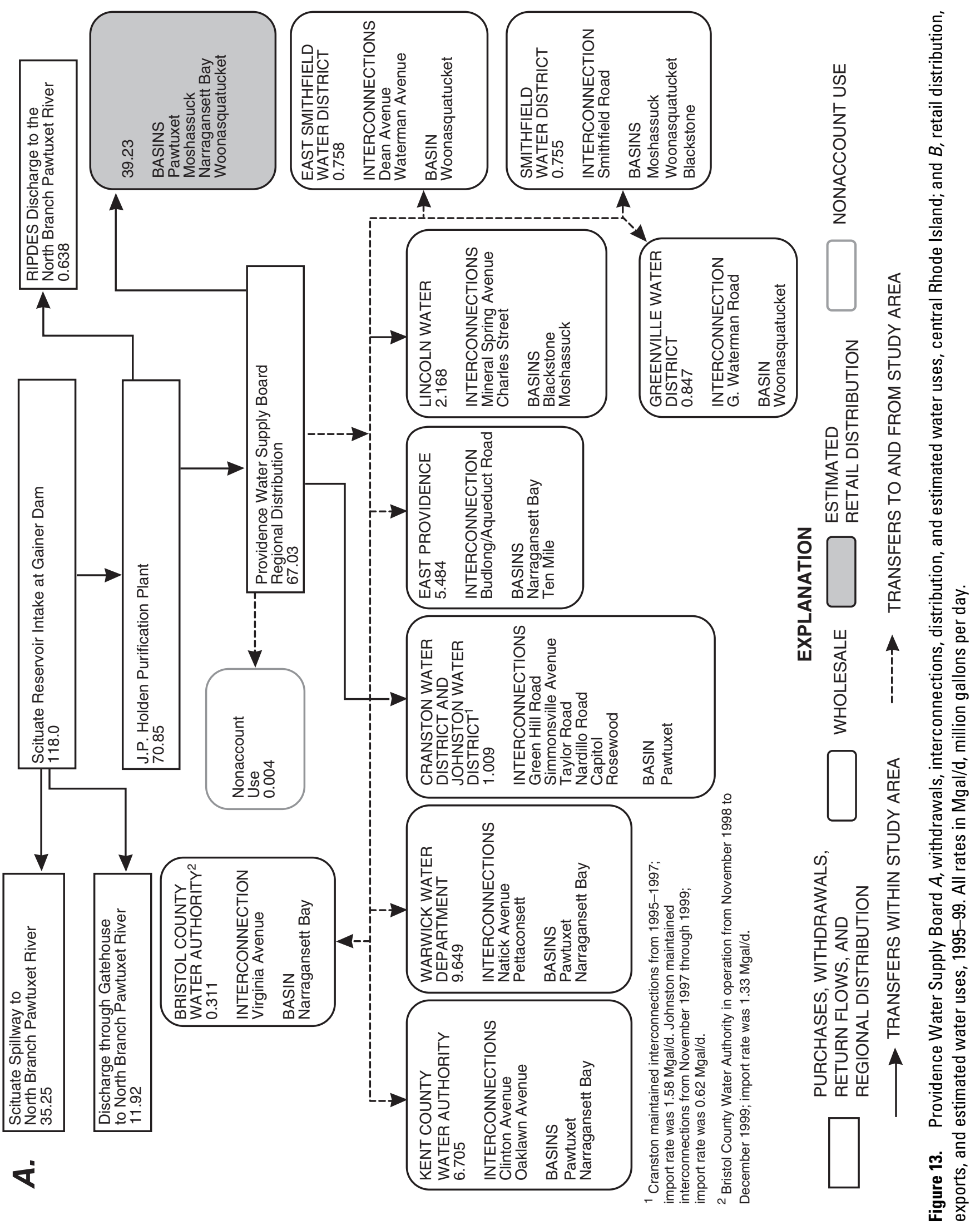



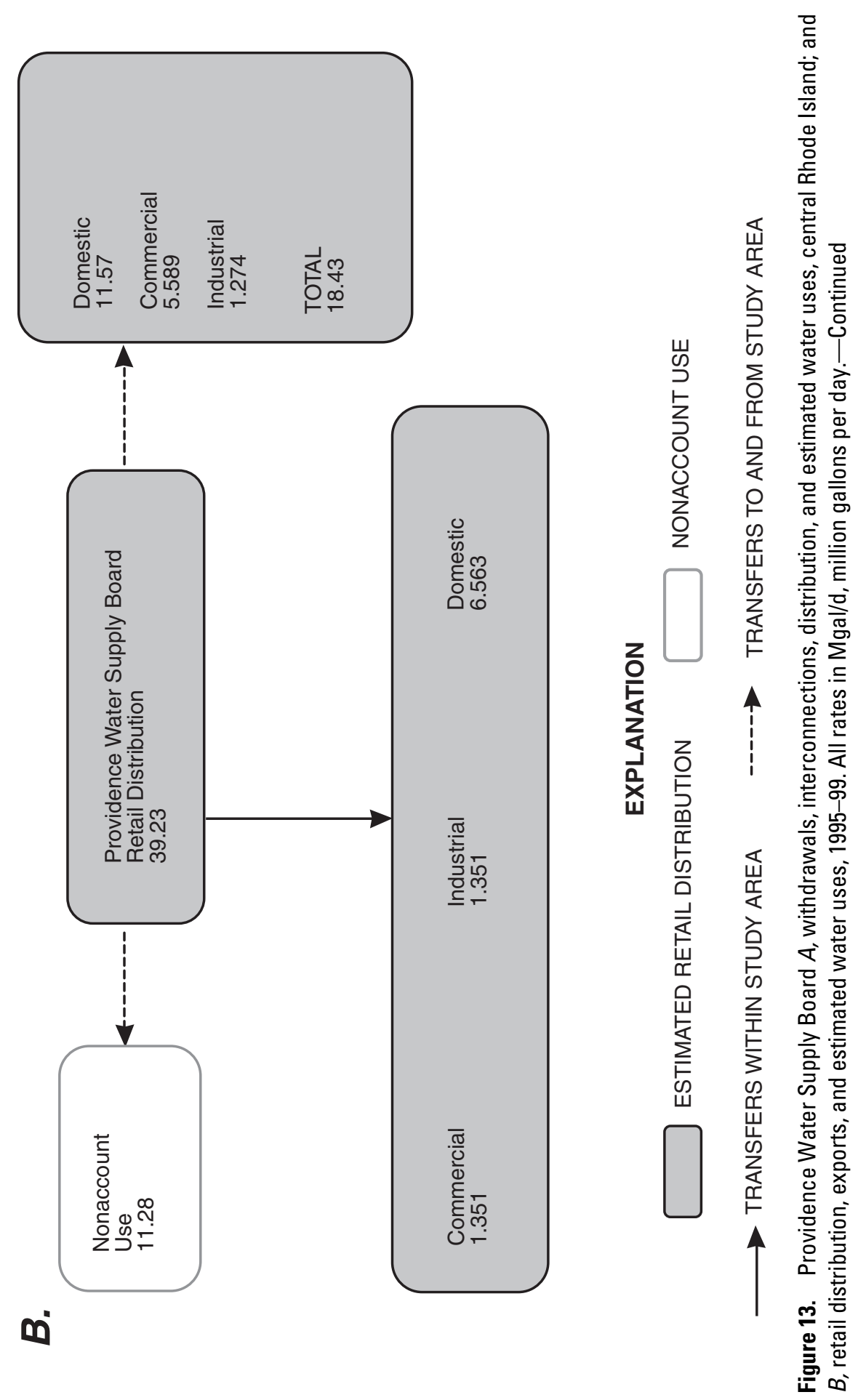
Table 11. Withdrawals, discharges, retail sales, and wholesale purchases for the Providence Water Supply Board system in June, July, August, and September, 1995-99.

[The Providence Water Supply Board withdraws from the Scituate Reservoir. ProvWater, Providence Water Supply Board; RIPDES, Rhode Island Pollutant Discharge Elimination System; Mgal/d, million gallons per day; --, not applicable]

\begin{tabular}{|c|c|c|c|c|c|}
\hline \multirow{2}{*}{$\begin{array}{l}\text { Transaction, resource name, } \\
\text { site type }\end{array}$} & \multirow{2}{*}{ Conveyance action } & \multicolumn{4}{|c|}{ Transaction rate (Mgal/d) } \\
\hline & & June & July & August & September \\
\hline $\begin{array}{l}\text { Intake from Scituate Reservoir, Scituate } \\
\text { Reservoir, intake pipe and surface-water } \\
\text { withdrawal }\end{array}$ & $\begin{array}{l}\text { From intake pipe and surface- } \\
\text { water withdrawal }\end{array}$ & 139.9 & 116.5 & 99.22 & 86.53 \\
\hline $\begin{array}{l}\text { Spillover to North Branch Pawtuxet River, } \\
\text { North Branch Pawtuxet Basin, surface-water } \\
\text { return flow }\end{array}$ & $\begin{array}{l}\text { From surface-water withdrawal } \\
\text { to surface water }\end{array}$ & 41.49 & 9.195 & -- & -- \\
\hline $\begin{array}{l}\text { Discharge through gatehouse to North Branch } \\
\text { Pawtuxet River, North Branch Pawtuxet } \\
\text { Basin, surface-water return flow }\end{array}$ & $\begin{array}{l}\text { From surface-water withdrawal } \\
\text { to surface water }\end{array}$ & 10.38 & 11.21 & 11.78 & 10.88 \\
\hline $\begin{array}{l}\text { Intake at J.P. Holton Purification Plant, --, } \\
\text { potable treatment plant }\end{array}$ & $\begin{array}{l}\text { From intake pipe to potable } \\
\text { treatment }\end{array}$ & 88.05 & 96.11 & 87.44 & 75.65 \\
\hline $\begin{array}{l}\text { Regional distribution from ProvWater, --, } \\
\text { regional distribution system }\end{array}$ & $\begin{array}{l}\text { From potable treatment to } \\
\text { regional distribution }\end{array}$ & 83.68 & 91.52 & 83.31 & 71.81 \\
\hline $\begin{array}{l}\text { Retail sales from ProvWater, --, local } \\
\text { distribution system }\end{array}$ & $\begin{array}{l}\text { From regional distribution to } \\
\text { local distribution }\end{array}$ & 47.86 & 49.23 & 46.18 & 40.45 \\
\hline $\begin{array}{l}\text { Wholesale purchases by East Smithfield Water } \\
\text { District, --, local distribution system }\end{array}$ & $\begin{array}{l}\text { From regional distribution to } \\
\text { local distribution }\end{array}$ & .935 & 1.077 & .914 & .783 \\
\hline $\begin{array}{l}\text { Wholesale purchases by Smithfield Water } \\
\text { Supply Board, --, local distribution system }\end{array}$ & $\begin{array}{l}\text { From regional distribution to } \\
\text { local distribution }\end{array}$ & .972 & 1.156 & 1.016 & .862 \\
\hline $\begin{array}{l}\text { Wholesale purchases by Greenville Water } \\
\text { District, --,local distribution system }\end{array}$ & $\begin{array}{l}\text { From regional distribution to } \\
\text { local distribution }\end{array}$ & 1.208 & 1.493 & 1.199 & .826 \\
\hline $\begin{array}{l}\text { Wholesale purchases by Warwick Water } \\
\text { Department, --, local distribution system }\end{array}$ & $\begin{array}{l}\text { From regional distribution to } \\
\text { local distribution }\end{array}$ & 13.25 & 16.98 & 14.80 & 11.72 \\
\hline $\begin{array}{l}\text { Wholesale purchases by Kent County Water } \\
\text { Authority, --, regional distribution system }\end{array}$ & $\begin{array}{l}\text { From regional distribution to } \\
\text { regional distribution }\end{array}$ & 7.852 & 8.418 & 7.533 & 6.620 \\
\hline $\begin{array}{l}\text { Wholesale purchases by Bristol County Water } \\
\text { Authority, --, regional distribution system }\end{array}$ & $\begin{array}{l}\text { From regional distribution to } \\
\text { regional distribution }\end{array}$ & .436 & .484 & .505 & .439 \\
\hline
\end{tabular}




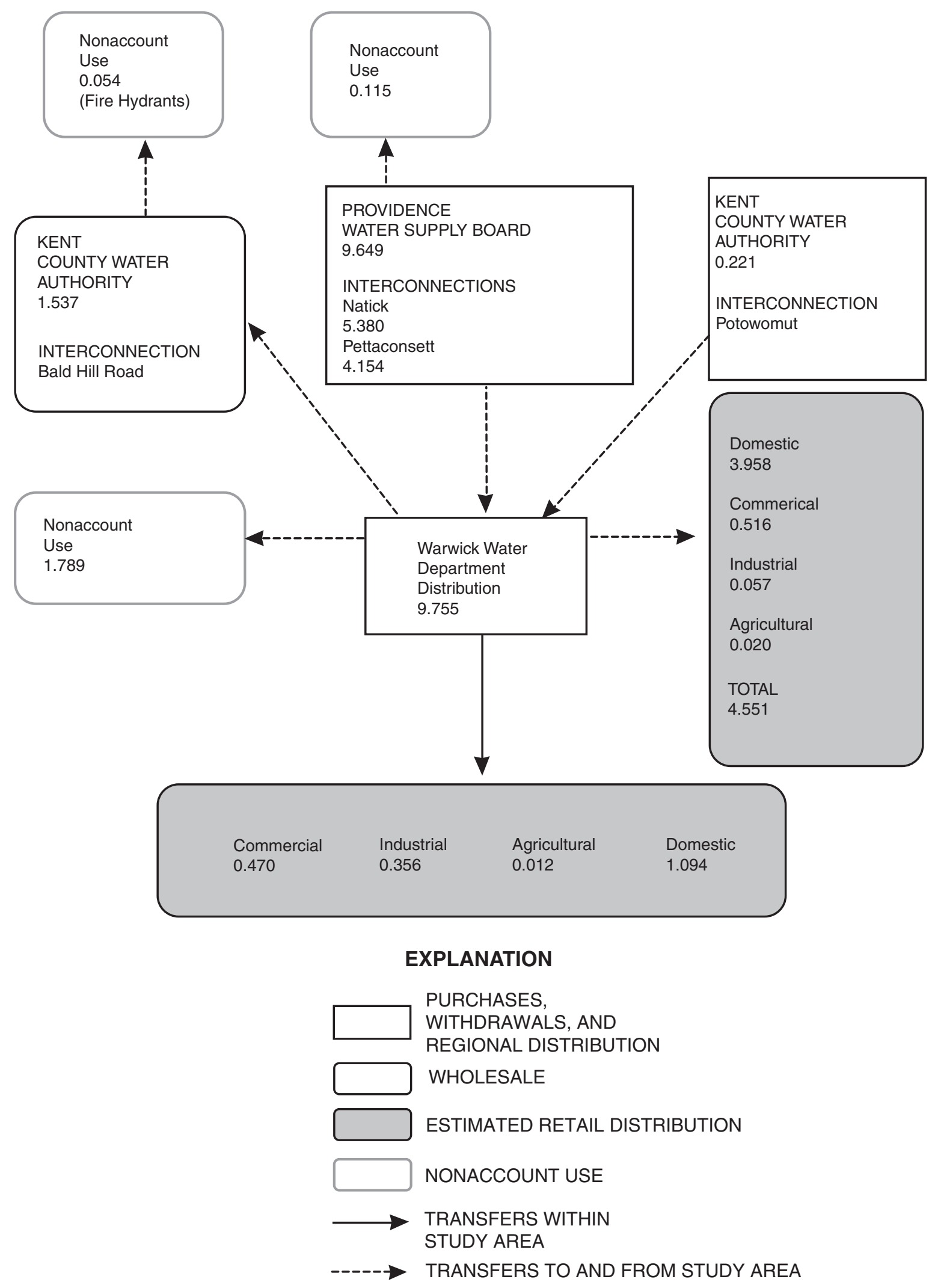

Figure 14. Warwick Water Department interconnections, purchases, distribution, exports, and estimated water uses, central Rhode Island, 1995-99. All rates in Mgal/d, million gallons per day. 
Public-supply domestic water use in the Pawtuxet River subbasins ranged from $0.072 \mathrm{Mgal} / \mathrm{d}$ in the Scituate Reservoir Complex subbasin to $8.147 \mathrm{Mgal} / \mathrm{d}$ in the Northeastern Pawtuxet subbasin. One minor public water supplier in the Quinebaug River Basin used an estimated $0.003 \mathrm{Mgal} / \mathrm{d}$ for domestic purposes (table 12).

\section{Self-Supply Use in the Pawtuxet and Quinebaug River Basins}

Domestic self-supply water withdrawals and use in the Pawtuxet subbasins ranged from $0.118 \mathrm{Mgal} / \mathrm{d}$ in the North Branch Pawtuxet subbasin to $0.956 \mathrm{Mgal} / \mathrm{d}$ in the Scituate Reservoir Complex subbasin (tables 9 and 12). Domestic self-supply water withdrawals and use in the Quinebaug were 0.319 $\mathrm{Mgal} / \mathrm{d}$ (tables 9 and 12).

\section{Commercial and Industrial Water Use}

Limited data are available on commercial and industrial water use from public- and self-supply systems, because withdrawals and use for these categories are not regulated in Rhode Island unless the withdrawal point is adjacent to a wetland (Rhode Island Department of Environmental Management, 2001). Commercial and industrial water-use estimates, therefore, were calculated for each town by apportioning the total commercial and industrial water uses by the percentage of the commercial and industrial land-use areas in each subbasin. Consumptive commercial and industrial water use (table 13) is assumed to be 10 percent of the total water use (Solley and others, 1998).

\section{Public-Supply Use in the Pawtuxet River Basin}

Information on commercial and industrial use of publicsupply water included metered (or reported) and unmetered (or estimated) water-use data. If the data were available, public suppliers provided the delivery volume and the number of service connections for commercial and industrial water users. In some cases, suppliers combined the water amounts supplied to commercial and industrial users, but in other cases, the information was not available. Government water use is accounted for within the commercial water-use category according to the Standard Industrial Classification (SIC) codes; however, government water use was entered as a separate distribution into NEWUDS. Because some public-supply district service areas are within one or more basins and subbasins, the public-supply commercial and industrial water uses were apportioned according to percentages of land-use areas (table 4). Land-use coverages from RIGIS were merged with the water-supply district, town, and basin coverages to obtain the percentages of commercial and industrial land use within the supply districts for towns served in the Pawtuxet River Basin. Commercial use of publicsupply water ranged from $0.015 \mathrm{Mgal} / \mathrm{d}$ in the Scituate Reser- voir Complex subbasin to $2.253 \mathrm{Mgal} / \mathrm{d}$ in the Northeastern Pawtuxet subbasin. Industrial use of public-supply water ranged from 0.001 Mgal/d in the Scituate Reservoir Complex subbasin to $1.843 \mathrm{Mgal} / \mathrm{d}$ in the Northeastern Pawtuxet subbasin (table 12).

\section{Self-Supply Use in the Pawtuxet and Quinebaug River Basins}

Self-supply commercial and industrial-use estimates were calculated from the employee counts published in the RIEDC's "Export/Import Directory" (2000a), "High Tech Industries in Rhode Island" (1999), and "Major Employers in Rhode Island" (2000b). The numbers of employees in the industrial and commercial sectors for each SIC code were multiplied by the U.S. Army Corp of Engineers' Institute for Water Resources Municipal and Industrial Needs (IWR-MAIN) water-use coefficient (in gal/d/person) for each town (table 14) as described in Horn (2000). The estimated public-supply commercial and industrial water-use rates were subtracted from the total aggregate wateruse rates to obtain the estimated total self-supply use for these categories. The total commercial and industrial water-use estimates for towns were disaggregated by basin (table 6) and then by subbasin on the basis of the land-use area by town as listed in table 3. Self-supply commercial use ranged from less than $0.001 \mathrm{Mgal} / \mathrm{d}$ in the North Branch Pawtuxet subbasin to 0.042 $\mathrm{Mgal} / \mathrm{d}$ in the Northeastern Pawtuxet subbasin. Self-supply industrial use ranged from 0.009 Mgal/d in the North Branch Pawtuxet subbasin to $0.082 \mathrm{Mgal} / \mathrm{d}$ in the South Branch Pawtuxet subbasin (tables 9 and 12).

\section{Agricultural Water Use}

The estimated agricultural water use (livestock, crop irrigation, and golf-course irrigation) was obtained from information provided by the Department of Agriculture (USDA) NRCS, formerly known as the USDA Soil Conservation Service (SCS). The estimate was calculated for each town and then disaggregated by state basin and subbasin. Nine percent of withdrawals and use for livestock were assumed to be from surface water (streams and ponds) and 82 percent from ground water (wells); these livestock water-use rates were previously estimated in a study completed by the SCS (1993). Likewise, eighty-one percent of withdrawals and use for irrigation (golf courses and crops) were assumed to be from surface water and 13 percent from ground water (SCS, 1993). The remaining 9 percent of livestock use and 6 percent of irrigation use were assumed to be from public-supply distributions.

The water-use coefficients for each type of livestock (Laura Medalie, U.S. Geological Survey, written commun., 1995) were multiplied by the number of livestock of each type. Because the livestock and crop-irrigation data are reported in the 1997 Census of Agriculture at the county level (U.S. Department of Agriculture, 1997a,b), the estimates were disaggregated on the basis of the number of farms in the towns in each 
Table 12. Estimated water supply by town and subbasin in the Pawtuxet River Basin, central Rhode Island, and in the Quinebaug River Basin, western Rhode Island, 1995-99.

[Shaded areas are basin totals. All towns are in Rhode Island unless otherwise noted. Mgal/d, million gallons per day; --, not applicable; $<0.001$, value not included in totals]

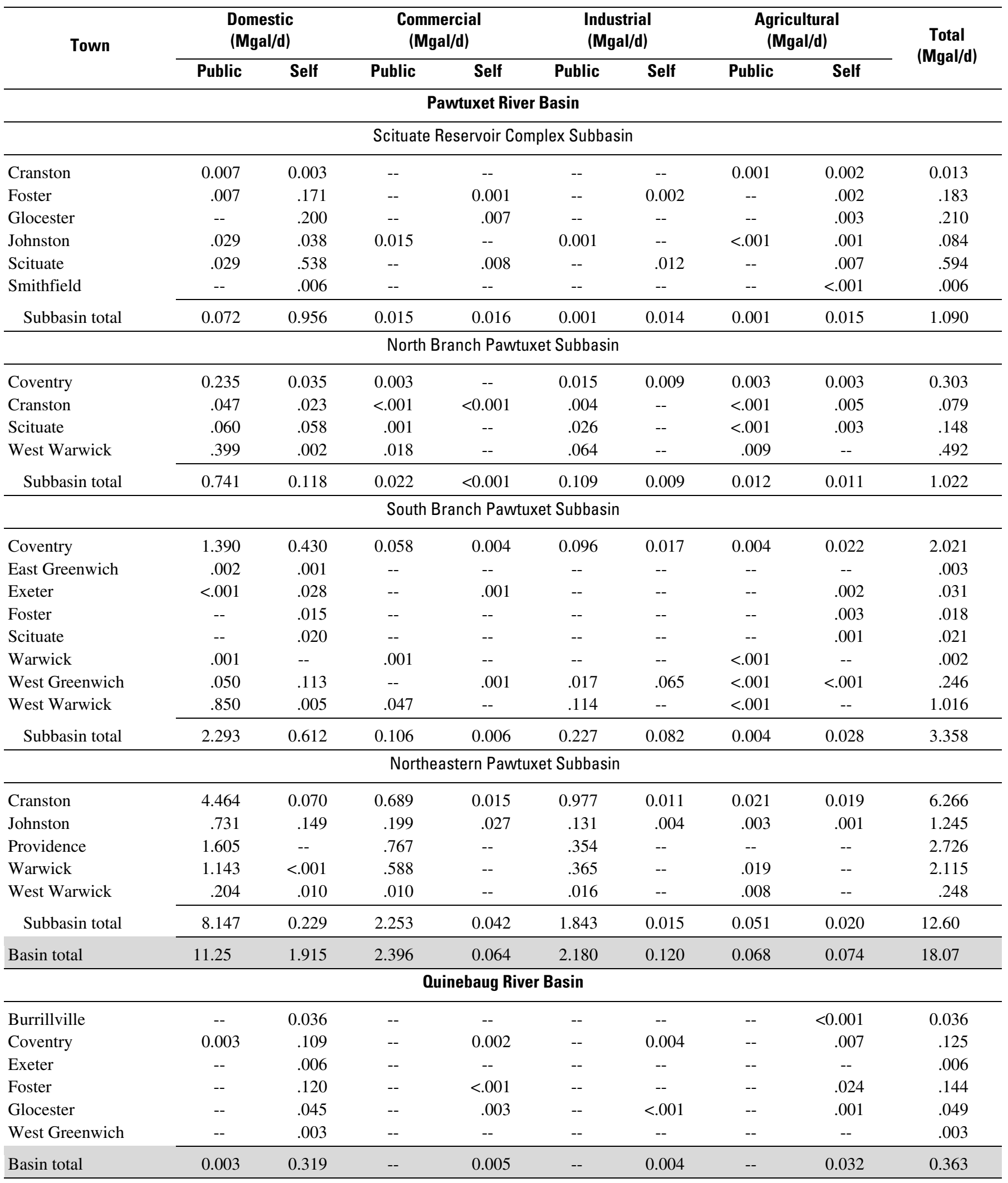


Table 13. Estimated consumptive water use by town and subbasin in the Pawtuxet River Basin, central Rhode Island, and in the Quinebaug River Basin, western Rhode Island, 1995-99.

[Shaded areas are basin totals. All towns are in Rhode Island unless otherwise noted. Mgal/d, million gallons per day; $<0.001$, value not included in totals; ,-- not applicable]

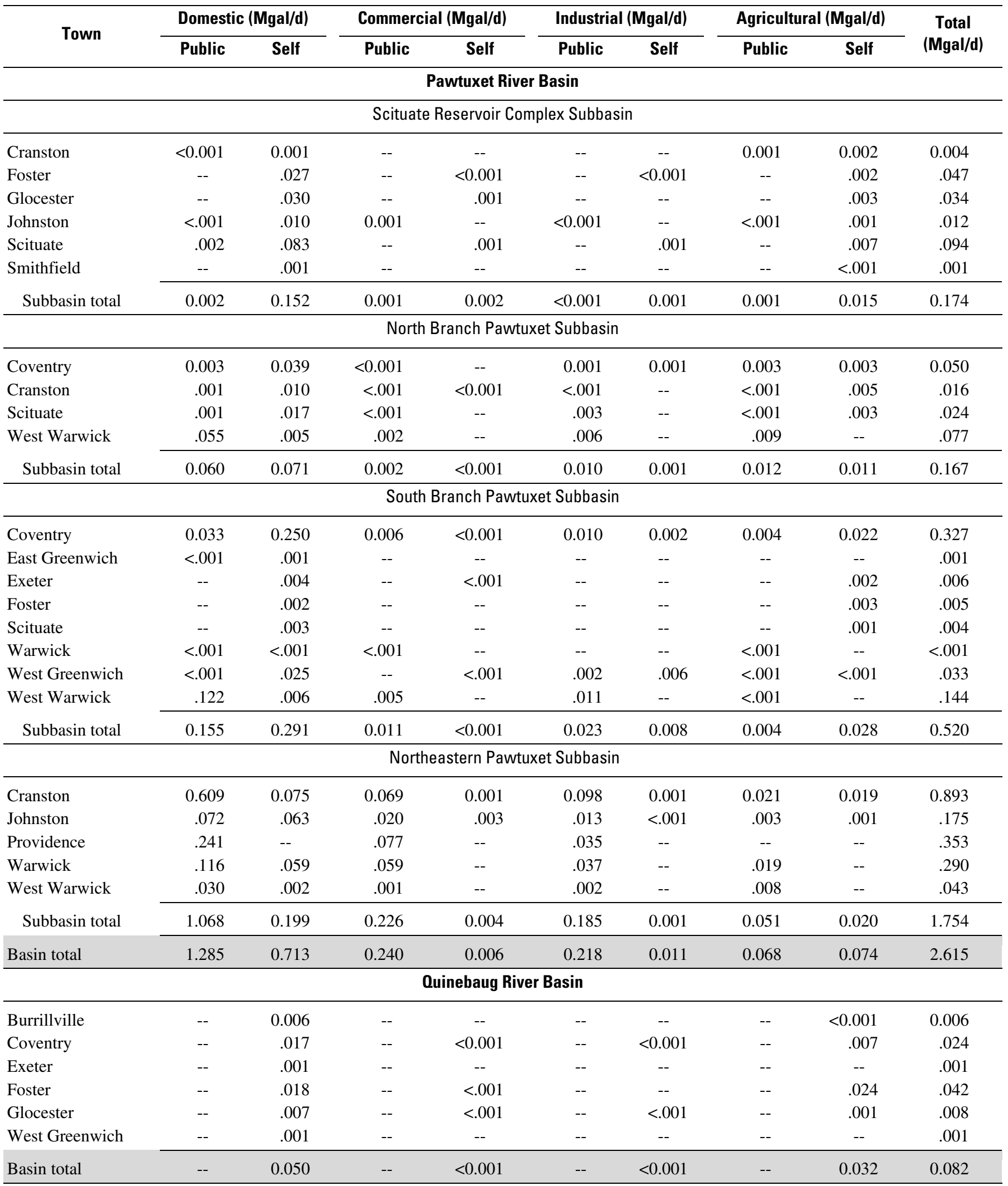


Table 14. Estimated water use for each 2-digit Standard Industrial Classification code by town in the Pawtuxet and Quinebaug River Basins, 1995-99.

[IWR-MAIN coefficient, Institute for Water Resources Municipal and Industrial Needs coefficient in millions of gallons per day per person; Mgal/d, million gallons per day; --, not applicable; $<0.001$, value not used in totals]

\begin{tabular}{|c|c|c|c|c|c|c|}
\hline \multirow{2}{*}{$\begin{array}{l}\text { 2-digit Standard Industrial Classification } \\
\text { category and [code] }\end{array}$} & \multirow{2}{*}{$\begin{array}{l}\text { IWR-MAIN } \\
\text { coefficient }\end{array}$} & \multicolumn{5}{|c|}{ Estimated water use in Rhode Island towns (Mgal/d) } \\
\hline & & Burrillville & Coventry & Cranston & $\begin{array}{c}\text { East } \\
\text { Greenwich }\end{array}$ & Exeter \\
\hline Food [20] & 469 & 0.033 & -- & 0.162 & 0.003 & -- \\
\hline Textile mills [22] & 315 & .016 & 0.022 & .008 & -- & -- \\
\hline Wood, lumber [24] & 78 & -- & -- & -- & -- & -- \\
\hline Furniture [25] & 3 & -- & -- & -- & -- & -- \\
\hline Paper products [26] & 863 & -- & -- & .237 & -- & -- \\
\hline Printing, publishing [27] & 42 & -- & -- & $<.001$ & $<.001$ & -- \\
\hline Chemical products [28] & 289 & -- & .102 & .069 & -- & -- \\
\hline Stone, clay, glass, and concrete [32] & 202 & -- & -- & .141 & -- & -- \\
\hline Primary metals [33] & 178 & -- & -- & .012 & .026 & -- \\
\hline Fabricated metal [34] & 95 & .011 & -- & .066 & .002 & -- \\
\hline Machinery [35] & 58 & -- & .009 & .029 & .085 & -- \\
\hline Electrical equipment [36] & 71 & -- & -- & .035 & .072 & -- \\
\hline Transportation equipment [37] & 63 & -- & -- & -- & -- & -- \\
\hline Instruments [38] & 66 & -- & .001 & .039 & .003 & -- \\
\hline Jewelry, precious metals [39] & 36 & -- & .008 & .040 & .003 & -- \\
\hline Total industrial [20-39] & -- & 0.067 & 0.142 & 0.995 & 0.194 & 0.024 \\
\hline \multicolumn{7}{|c|}{ Commercial [40-97] } \\
\hline Total commercial [40-97] & -- & 0.051 & 0.068 & 0.726 & 0.023 & 0.017 \\
\hline
\end{tabular}


Table 14. Estimated water use for each 2-digit Standard Industrial Classification code by town in the Pawtuxet and Quinebaug River Basins, 1995-99.-Continued

[IWR-MAIN coefficient, Institute for Water Resources Municipal and Industrial Needs coefficient in millions of gallons per day per person; Mgal/d, million gallons per day; --, not applicable; $<0.001$, value not used in totals]

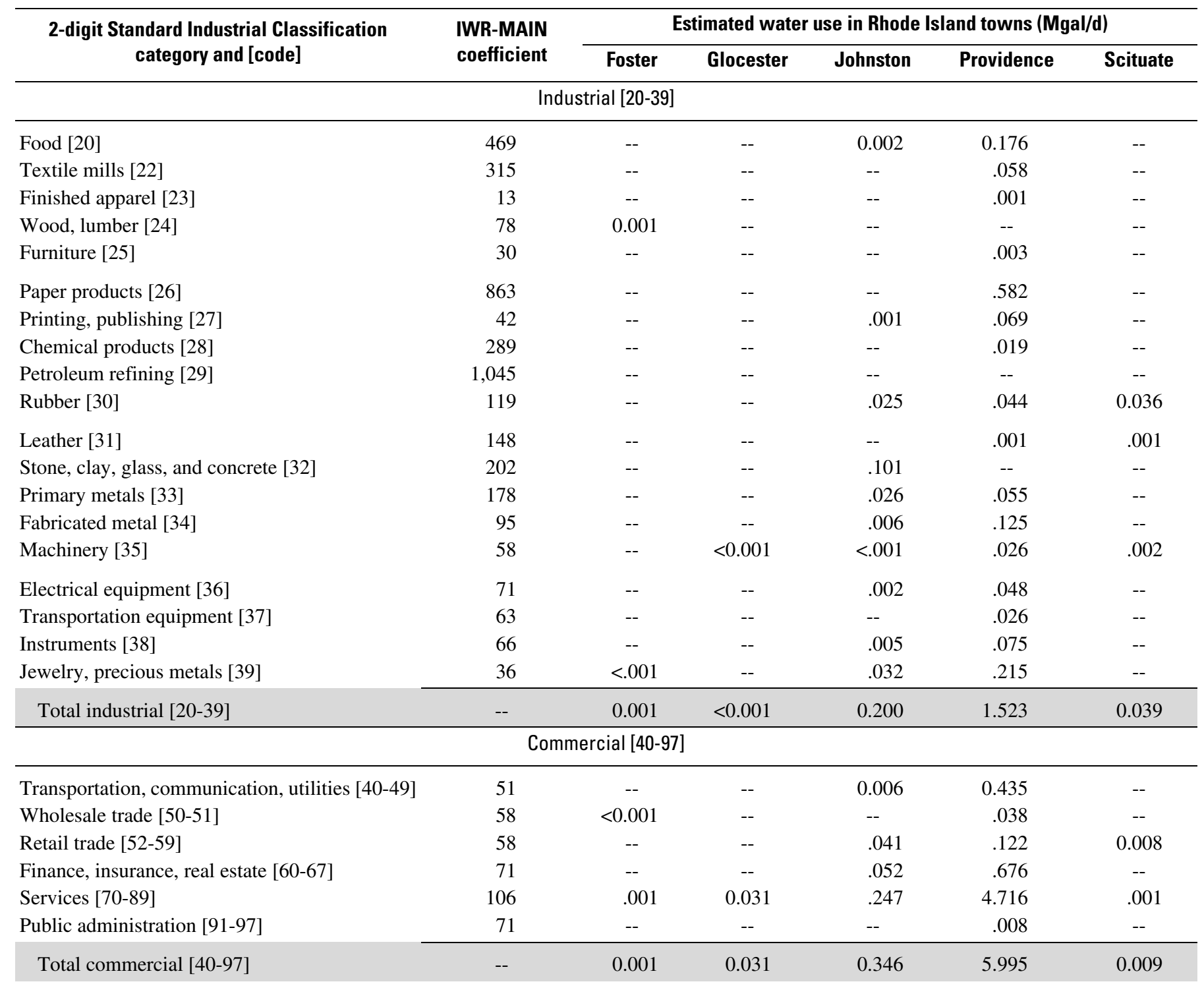


Table 14. Estimated water use for each 2-digit Standard Industrial Classification code by town in the Pawtuxet and Quinebaug River Basins, 1995-99.-Continued

[IWR-MAIN coefficient, Institute for Water Resources Municipal and Industrial Needs coefficient in millions of gallons per day per person; Mgal/d, million gallons per day; --, not applicable; $<0.001$, value not used in totals]

\begin{tabular}{|c|c|c|c|c|c|}
\hline \multirow[b]{2}{*}{$\begin{array}{l}\text { 2-digit Standard Industrial Classification } \\
\text { category and [code] }\end{array}$} & \multirow[b]{2}{*}{$\begin{array}{l}\text { IWR-MAIN } \\
\text { coefficient }\end{array}$} & \multicolumn{4}{|c|}{ Estimated water use in Rhode Island towns (Mgal/d) } \\
\hline & & Smithfield & Warwick & $\begin{array}{c}\text { West } \\
\text { Greenwich }\end{array}$ & $\begin{array}{c}\text { West } \\
\text { Warwick }\end{array}$ \\
\hline \multicolumn{6}{|c|}{ Industrial [20-39] } \\
\hline Food [20] & 469 & 0.077 & 0.009 & -- & -- \\
\hline Textile mills [22] & 315 & -- & .031 & 0.009 & 0.090 \\
\hline Finished apparel [23] & 13 & -- & -- & -- & -- \\
\hline Wood, lumber [24] & 78 & -- & -- & -- & -- \\
\hline Furniture [25] & 30 & .003 & .017 & -- & -- \\
\hline Paper products [26] & 863 & -- & .022 & -- & -- \\
\hline Printing, publishing [27] & 42 & -- & .007 & -- & -- \\
\hline Chemical products [28] & 289 & -- & .010 & .068 & .147 \\
\hline Petroleum refining [29] & 1045 & -- & -- & -- & -- \\
\hline Rubber [30] & 119 & -- & .004 & .003 & .015 \\
\hline Leather [31] & 148 & -- & -- & -- & -- \\
\hline Stone, clay, glass, and concrete [32] & 202 & .006 & -- & -- & .015 \\
\hline Primary metals [33] & 178 & .011 & .039 & -- & -- \\
\hline Fabricated metal [34] & 95 & .001 & .050 & -- & .060 \\
\hline Machinery [35] & 58 & .005 & .026 & .058 & .008 \\
\hline Electrical equipment [36] & 71 & .003 & .146 & -- & .031 \\
\hline Transportation equipment [37] & 63 & .002 & -- & -- & -- \\
\hline Instruments [38] & 66 & .032 & .038 & -- & -- \\
\hline Jewelry, precious metals [39] & 36 & .019 & .054 & -- & .001 \\
\hline Total industrial [20-39] & -- & 0.159 & 0.453 & 0.138 & 0.367 \\
\hline \multicolumn{6}{|c|}{ Commercial [40-97] } \\
\hline Transportation, communication, utilities [40-49] & 51 & -- & 0.075 & 0.001 & 0.020 \\
\hline Wholesale trade [50-51] & 58 & -- & .008 & -- & -- \\
\hline Retail trade [52-59] & 58 & 0.030 & .363 & -- & .006 \\
\hline Finance, insurance, real estate [60-67] & 71 & .076 & .166 & -- & .066 \\
\hline Services [70-89] & 106 & .143 & .892 & -- & .014 \\
\hline Public administration [91-97] & 71 & -- & -- & -- & -- \\
\hline Total commercial [40-97] & -- & 0.249 & 1.504 & 0.001 & 0.106 \\
\hline
\end{tabular}


county and the percentage of agricultural land use in each town and subbasin. The livestock water-use estimates represent a year-round usage. Although it is estimated that 60 percent of livestock water use is consumed and 40 percent is returned to ground water (Horn and others, 1994), this distinction was negligible for the Pawtuxet and Quinebaug River Basins. Thus, agricultural water use was assumed to be 100 percent consumed (table 13) (Horn and others, 1994). Livestock water use accounted for about 13 percent of the agricultural water withdrawals and about 0.01 percent of the total water withdrawals during the study period, and thus was a minor component of water use in the Pawtuxet River Basin. In the Quinebaug River Basin, livestock water withdrawals accounted for 6.3 percent of the agricultural withdrawals and about 0.5 percent of the total water withdrawals.

Crop and golf-course irrigation were estimated on the basis of the assumption that the percentage of agricultural landuse area for each town is equal to the percentage of the total town agricultural land-use area in the county. The irrigated town acreage determined from the estimation was then subdivided by basin and subbasin. For irrigated acreage in the Pawtuxet River Basin, it was assumed that $1 \mathrm{in} /$ week/acre of water (an average of $0.143 \mathrm{in} /$ day/acre) was needed to irrigate crop land (Laura Medalie, U.S. Geological Survey, written commun., 2000). The monthly water deficit was determined by subtracting the average monthly rainfall from the $0.143 \mathrm{in} /$ day/acre needed for crop irrigation. Yardages for the golf courses were collected from the websites WorldGolf.com (2002) and GolfCourse.com (2002). The coefficient of $0.0116 \mathrm{Mgal} / \mathrm{d}$ per 1,000 yards (Laura Medalie, U.S. Geological Survey, written commun., 2000) was applied to the golf-course areas in the towns in the Pawcatuck Basin (Wild and Nimiroski, 2004) and was used in this study. The coefficient used for the 2000 water-use compilation for Massachusetts was comparable at $0.0117 \mathrm{Mgal} / \mathrm{d}$ per 1,000 yards (Wild and Nimiroski, 2004). According to the SCS (1993), most of the irrigation occurred during June, July, and August. There was no crop and golf-course irrigation in the Quinebaug River Basin during the study period.

Self-supply agricultural water use was estimated by town and disaggregated by basin and subbasin. In the Pawtuxet River Basin, self-supply water withdrawals and use for agriculture ranged from $0.011 \mathrm{Mgal} / \mathrm{d}$ in the North Branch Pawtuxet subbasin to $0.028 \mathrm{Mgal} / \mathrm{d}$ in the South Branch Pawtuxet subbasin (tables 9 and 12). In the Quinebaug River Basin, self-supply water withdrawals and use for agriculture ranged from less than $0.001 \mathrm{Mgal} / \mathrm{d}$ in Burrillville to $0.024 \mathrm{Mgal} / \mathrm{d}$ in Foster (tables 9 and 12). Agricultural water withdrawals and use in the Quinebaug River Basin were 0.032 Mgal/d (tables 9 and 12).

\section{Return Flow and Interbasin Transfers}

In Rhode Island, commercial and industrial dischargers are required to report to the RIDEM Office of Water Resources the rates of water returned to the environment. These dischargers, referred to as Rhode Island Pollutant Discharge Elimination Systems (RIPDES), return wastewater to surface water (usually to rivers), or in some cases, to the ground-water system. In addi- tion, local and regional facilities that treat wastewater are required to report wastewater discharges into rivers in Rhode Island. Domestic, commercial, and industrial disposers who use septic systems, which create inflow to the ground-water system, are not required to report discharges. For the Pawtuxet River Basin, the total metered RIPDES return flow was 5.903 Mgal/d, and the total metered wastewater from treatment facilities was 20.54 Mgal/d (table 15). The return flow from RIPDES sites and WWTFs totaled $26.28 \mathrm{Mgal} / \mathrm{d}$ to surface water, and 0.163 $\mathrm{Mgal} / \mathrm{d}$ to ground water. The estimated return flow from septic systems was $4.031 \mathrm{Mgal} / \mathrm{d}$ for domestic disposers, 0.058 $\mathrm{Mgal} / \mathrm{d}$ for commercial disposers, and $0.109 \mathrm{Mgal} / \mathrm{d}$ for industrial disposers (table 15). Therefore, the Pawtuxet River Basin total estimated ground-water return flow was $4.361 \mathrm{Mgal} / \mathrm{d}$ for the study period. The estimated return flow from septic systems, the only return flow in the Quinebaug River Basin, was 0.274 $\mathrm{Mgal} / \mathrm{d}$ for domestic disposers, $0.005 \mathrm{Mgal} / \mathrm{d}$ for commercial disposers, and $0.004 \mathrm{Mgal} / \mathrm{d}$ for industrial disposers (table 15).

Interbasin transfers include imports and exports of wastewater and potable water to and from a basin or subbasin. Wastewater is an import, or a gain to the Pawtuxet River Basin, if it is collected in another basin or subbasin and conveyed to the Pawtuxet River Basin for discharge. Wastewater is an export, or a loss to the basin, when it is collected and processed in the basin but is returned to the environment outside the basin.

\section{Site-Specific Return Flow in the Pawtuxet River Basin}

Some RIPDES systems are required to report their discharges to RIDEM. Return-flow data were collected from RIDEM for these small systems - for example, wastewatertreatment plants (Horn and Craft, 1991) — in the Pawtuxet River Basin (table 16). Return flows are conveyed by discharge pipes that dispose water used during industrial and commercial processes. Total RIPDES discharges in the Pawtuxet River Basin were $5.903 \mathrm{Mgal} / \mathrm{d}$, and ranged from $0.001 \mathrm{Mgal} / \mathrm{d}$ in the Scituate Reservoir Complex subbasin to $4.479 \mathrm{Mgal} / \mathrm{d}$ in the South Branch Pawtuxet subbasin (tables 15 and 16).

Monthly data were collected for wastewater-treatment facilities in or serving the town populations in the Pawtuxet River Basin (table 17), including the Cranston Water Pollution Control Facility, the Warwick WWTF, the West Warwick Regional WWTF, and the Narragansett Bay Commission Fields Point Facility. Cranston, Warwick, and West Warwick wastewater is collected in the Pawtuxet River Basin and in the adjacent West Narragansett Bay Basin, and the treated return flow is discharged to the Pawtuxet River in the Northeastern Pawtuxet subbasin. Average discharges to the Pawtuxet River were 11.69 Mgal/d from the Cranston system, 3.642 Mgal/d from the Warwick system, and 5.204 Mgal/d from the West Warwick system. These totals include wastewater collected in the Pawtuxet River Basin and imported from outside of the basin. An estimated 3.092 Mgal/d of wastewater is collected from the parts of Johnston and Providence in the Pawtuxet River Basin and exported to the adjacent West Narragansett Bay Basin (table 17). 
Table 15. Estimated public- and self-disposed domestic, commercial, industrial, and metered return flow by subbasin in the Pawtuxet River Basin, central Rhode Island, and in the Quinebaug River Basin, western Rhode Island, 1995-99.

[Shaded areas are basin totals. Public disposal, wastewater collection to treatment plant; Self-disposal, inflow to ground water; RIPDES and WWTFs, inflow to surface water; RIPDES, Rhode Island Pollutant Discharge Elimination System; WWTF, wastewater-treatment facilities; Mgal/d, million gallons per day; $<0.001$, value not included in totals; --, not applicable]

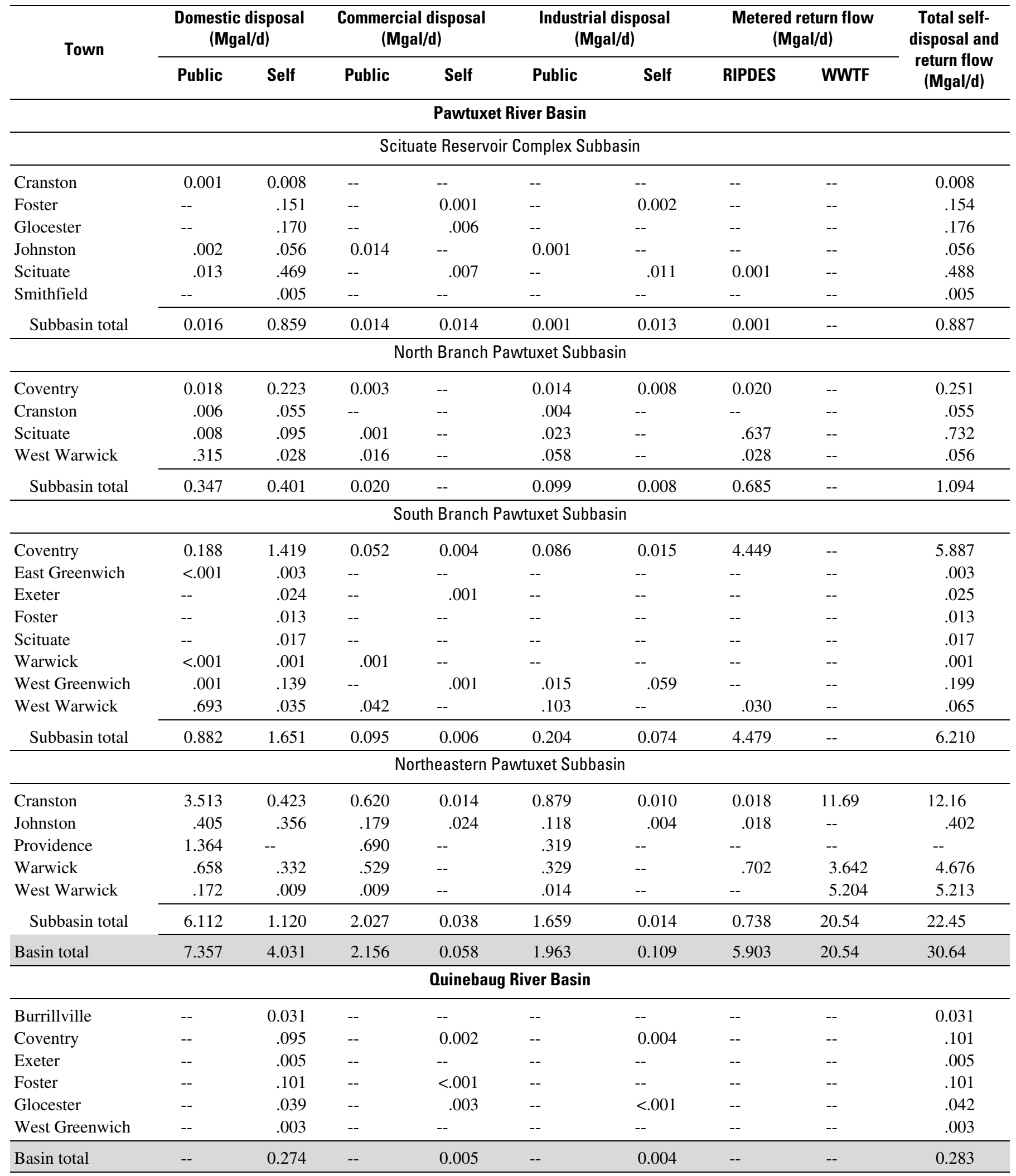


Table 16. Return flows by subbasin for the Rhode Island Pollutant Discharge Elimination System sites in the Pawtuxet River Basin, central Rhode Island, 1995-99.

[Shaded area represents basin total. Reference Number: The identifier for sites shown on figure 8. SIC, Standard Identification Code; Mgal/d, million gallons per day; MHRH, Mental Health, Retardation and Hospitals; RI, Rhode Island; --, unknown]

\begin{tabular}{|c|c|c|c|c|c|c|}
\hline Return-flow site & $\begin{array}{c}\text { Reference } \\
\text { number }\end{array}$ & Town & $\begin{array}{c}\text { Discharge } \\
\text { permit } \\
\text { number }\end{array}$ & $\begin{array}{l}\text { Receiving } \\
\text { water body }\end{array}$ & $\begin{array}{c}\text { SIC } \\
\text { code }\end{array}$ & $\begin{array}{c}\text { Return flow } \\
\text { 1995-99 } \\
\text { (Mgal/d) }\end{array}$ \\
\hline \multicolumn{7}{|c|}{ Pawtuxet River Basin } \\
\hline \multicolumn{7}{|c|}{ Scituate Reservoir Complex Subbasin } \\
\hline Kenyon Oil Company & 1 & Scituate & RI0023191 & $-{ }_{-1}^{1}$ & 5541 & 0.001 \\
\hline \multicolumn{7}{|c|}{ North Branch Pawtuxet Subbasin } \\
\hline Providence Water Supply Board & 2 & Scituate & RI0021601 & North Branch Pawtuxet River & 4941 & 0.637 \\
\hline Arkwright, Inc. & 3 & Coventry & RI0000035 & North Branch Pawtuxet River & 3081 & .020 \\
\hline Victor Electric Wire & 4 & West Warwick & RI0001473 & North Branch Pawtuxet River & 3357 & .028 \\
\hline \multicolumn{7}{|c|}{ South Branch Pawtuxet Subbasin } \\
\hline Garland Industries & 6 & Coventry & RI0021075 & South Branch Pawtuxet River & 3951 & $--^{2}$ \\
\hline Clarient Corporation & 7 & Coventry & RI0000132 & South Branch Pawtuxet River & 2865 & 4.449 \\
\hline Concordia Manufacturing & 8 & Coventry & RI0000981 & South Branch Pawtuxet River & 2282 & $<.001$ \\
\hline Coventry Narrow Fabrics & 9 & Coventry & RI0021580 & South Branch Pawtuxet River & 2241 & $<.001$ \\
\hline Original Bradford Soap Works & 10 & West Warwick & RI0000248 & South Branch Pawtuxet River & 2841 & .030 \\
\hline Subbasin total & & & & & & 4.479 \\
\hline \multicolumn{7}{|c|}{ Northeastern Pawtuxet Subbasin } \\
\hline Medical Homes of Rhode Island & 11 & Johnston & RI0020168 & Dry Brook & 8051 & 0.018 \\
\hline Coastal Food Service & 12 & Cranston & RI0021687 & Print Works Pond & 3589 & .001 \\
\hline Rhode Island Mall & 20 & Warwick & RI0001546 & Pawtuxet River & 7389 & $<.001$ \\
\hline Subbasin total & & & & & & 0.738 \\
\hline Basin total & & & & & & 5.903 \\
\hline
\end{tabular}

\footnotetext{
${ }^{1}$ The receiving water body is not specified in the NEWUDS database. In this report, return flows were assumed to be discharged directly to the local aquifer and were treated as such in the calculation of water budgets.

${ }^{2}$ No data for period of study (1995-99).
} 
Table 17. Return flow from wastewater-treatment facilities within and outside of the Pawtuxet River Basin, central Rhode Island, 1995-99.

[Reference letter: Identifier used on fig. 8. Mgal/d, million gallons per day]

\begin{tabular}{|c|c|c|c|c|}
\hline Wastewater-treatment facility & $\begin{array}{l}\text { Reference } \\
\text { letter }\end{array}$ & $\begin{array}{c}\text { Discharge } \\
\text { permit } \\
\text { number }\end{array}$ & $\begin{array}{l}\text { Receiving water body } \\
\text { (subbasin or basin) }\end{array}$ & $\begin{array}{c}\text { Average } \\
\text { discharge } \\
1995-99 \\
\text { (Mgal/d) }\end{array}$ \\
\hline \multicolumn{5}{|c|}{ Return flow to the Pawtuxet River Basin } \\
\hline Cranston Water Pollution-Control Facility & A & RI0100013 & $\begin{array}{l}\text { Pawtuxet River } \\
\quad \text { (Northeastern Pawtuxet Subbasin) }\end{array}$ & 11.69 \\
\hline $\begin{array}{l}\text { West Warwick Regional Wastewater-Treatment } \\
\text { Facility }\end{array}$ & $\mathrm{C}$ & RI0100153 & $\begin{array}{l}\text { Pawtuxet River } \\
\quad \text { (Northeastern Pawtuxet Subbasin) }\end{array}$ & 5.204 \\
\hline Total & & & & $1_{20.54}$ \\
\hline \multicolumn{5}{|c|}{ Return flow outside of the Pawtuxet River Basin } \\
\hline Total & & & & 55.44 \\
\hline
\end{tabular}

\section{Aggregate Return Flow in the Pawtuxet and Quinebaug River Basins}

Aggregate return flow was estimated for domestic, industrial, and commercial water use. Domestic populations on septic systems were assumed to return 85 percent of their wastewater to ground water and to consume 15 percent of the water withdrawn (Solley and others, 1998). To estimate the rate of domestic self-disposal of wastewater, the population was multiplied by the water-use coefficient for self-supply water use (71 gal/d/person), converted to Mgal/d, and multiplied by 85 percent. Domestic rates of self-disposal of wastewater in the Pawtuxet River Basin ranged from $0.401 \mathrm{Mgal} / \mathrm{d}$ in the North Branch Pawtuxet subbasin to $1.651 \mathrm{Mgal} / \mathrm{d}$ in the South Branch Pawtuxet subbasin; in the Quinebaug River Basin, the rate was $0.274 \mathrm{Mgal} / \mathrm{d}$ (table 15). It is estimated that 90 percent of industrial and commercial return flow is disposed to ground water and 10 percent is consumed (Horn, 2000). Commercial rates of self-disposal of wastewater in the Pawtuxet River Basin ranged from none in the North Branch Pawtuxet subbasin to 0.038 $\mathrm{Mgal} / \mathrm{d}$ in the Northeastern Pawtuxet subbasin; in the Quinebaug River Basin, the rate was $0.005 \mathrm{Mgal} / \mathrm{d}$. Industrial rates of self-disposal of wastewater in the Pawtuxet River Basin ranged from $0.008 \mathrm{Mgal} / \mathrm{d}$ in the North Branch Pawtuxet subbasin to $0.074 \mathrm{Mgal} / \mathrm{d}$ in the South Branch Pawtuxet subbasin; in the Quinebaug River Basin, the rate was $0.004 \mathrm{Mgal} / \mathrm{d}$ (table 15). Total consumptive water-use rates in the Pawtuxet River Basin ranged from $0.167 \mathrm{Mgal} / \mathrm{d}$ in the North Branch Pawtuxet subbasin to $1.754 \mathrm{Mgal} / \mathrm{d}$ in the Northeastern Pawtuxet subbasin, and the rate for the Quinebaug River Basin was $0.082 \mathrm{Mgal} / \mathrm{d}$ (table 13).

\section{Interbasin Transfers in the Pawtuxet River Basin}

The public water supply withdrawn from the Scituate Reservoir Complex subbasin by ProvWater supplied almost all of the other basins in Rhode Island, including the Blackstone, the Moshassuck, the Woonasquatucket, the Narragansett Bay, and the Westport Basins; only the Quinebaug, the Pawcatuck, and the South Coastal Basins were not supplied by the Scituate Reservoir. In addition, withdrawals from the Kent County Water Authority supplied areas outside of the Pawtuxet River Basin. Of the major public-supply withdrawals from the Pawtuxet River Basin, about 22 percent were used (domestic, commercial, industrial, and agricultural uses) in the Pawtuxet River Basin, and about 51 percent were exported to other basins in Rhode Island (fig. 15). The remaining water use was classified as nonaccount. Some of the water exported from the basin was returned to the basin as wastewater. A comparison of the total water withdrawals from the basin to the total use and nonaccount water losses resulted in a net export of $48.48 \mathrm{Mgal} / \mathrm{d}$ of potable water from the Pawtuxet River Basin (table 18). 


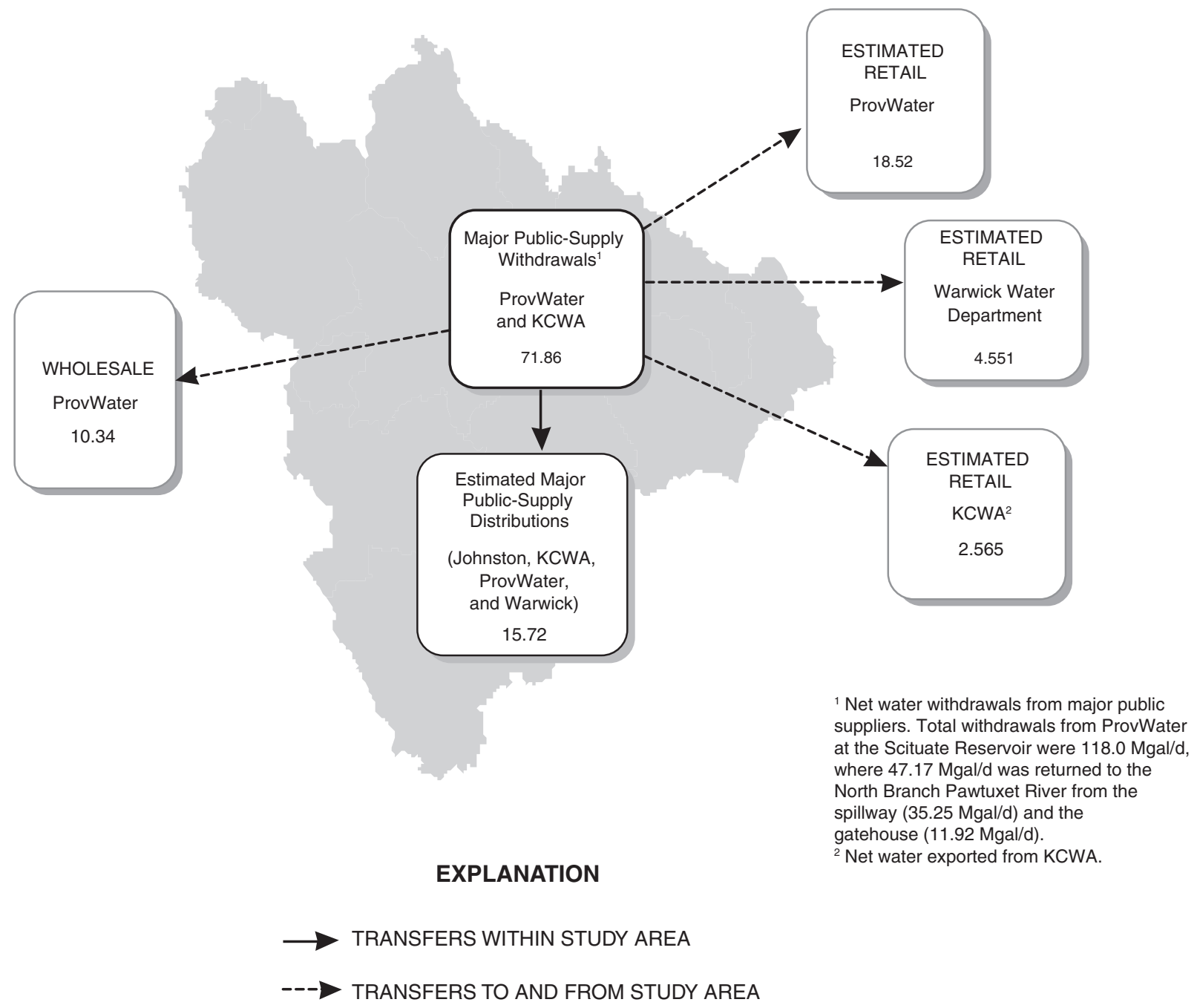

Figure 15. Public-supply withdrawals and estimated exports from the Pawtuxet River Basin, central Rhode Island, 1995-99. All rates in Mgal/d, million gallons per day. [ProvWater, Providence Water Supply Board; KCWA, Kent County Water Authority] 
Within the water balance of withdrawals, use by category, nonaccount use, consumptive use, and return flows, a percent error can be attributed to the addition of metered (or reported) and estimated water-use components for each category. Publicsupply withdrawals are metered (or reported), for example, but water use by subbasin is estimated, and then the return flow is metered (or reported) and estimated. Similarly, RIPDES data are metered (or reported), but the rates of withdrawal and use are estimated.

Wastewater is collected from the Pawtuxet River Basin and outside the basin, and then it is processed and returned to the Pawtuxet River from the towns of Cranston, Warwick, and West Warwick. Wastewater from the Pawtuxet River Basin is also exported in Johnston and Providence to the Narragansett Bay Basin, where the wastewater is processed and returned to Narragansett Bay (fig. 16). Estimated rates of publicly disposed industrial and commercial water were used to determine wastewater imports and exports. In the Pawtuxet River Basin, the net import of wastewater was $15.19 \mathrm{Mgal} / \mathrm{d}$ (table 18). The only exports from the Quinebaug River Basin are losses from consumptive water use, and were $0.136 \mathrm{Mgal} / \mathrm{d}$ (table 19).

Table 18. Summary of estimated water withdrawals, imports, exports, use, consumptive use, and return flow in the Pawtuxet River Basin, central Rhode Island, 1995-99.

[Nonaccount: A loss of water through the system. Consumptive use: A basin export. Net import and exports: The sum of the potable water and wastewater imports and exports; does not include nonaccount and consumptive water uses. AG, agricultural; COM, commercial; DOM, domestic; IND, industrial; $\mathrm{Mgal} / \mathrm{d}$, million gallons per day; $<0.001$, values not included in town and subbasin totals; + , potable distribution and wastewater imported to subbasin and basin; -, potable distribution and wastewater exported from subbasin and basin; --, not applicable]

\begin{tabular}{|c|c|c|c|c|c|c|c|c|c|}
\hline Subbasin & $\begin{array}{c}\begin{array}{c}\text { Water } \\
\text { withdrawals } \\
\text { (Mgal/d) }\end{array} \\
\begin{array}{c}\text { Public } \\
\text { and self }\end{array}\end{array}$ & $\begin{array}{c}\text { Potable } \\
\text { water } \\
\text { imports (+) } \\
\text { and exports (-) } \\
\text { (Mgal/d) }\end{array}$ & \multicolumn{2}{|c|}{$\begin{array}{l}\text { Total water use, } \\
\text { public and self } \\
\text { (Mgal/d) }\end{array}$} & $\begin{array}{l}\text { Consump- } \\
\text { tive use } \\
\text { (Mgal/d) }\end{array}$ & \multicolumn{2}{|c|}{$\begin{array}{c}\text { Return flow } \\
\text { (Mgal/d) }\end{array}$} & $\begin{array}{l}\text { Wastewater } \\
\text { imports (+) } \\
\text { and } \\
\text { exports (-) } \\
\text { (Mgal/d) }\end{array}$ & $\begin{array}{c}\text { Net } \\
\text { imports (+) } \\
\text { and } \\
\text { exports (-) } \\
\text { (Mgal/d) }\end{array}$ \\
\hline $\begin{array}{l}\text { Scituate Reservoir } \\
\text { Complex }\end{array}$ & 71.87 & -70.77 & 1.090 & 0.011 & 0.174 & -- & 0.887 & -0.029 & -70.80 \\
\hline $\begin{array}{l}\text { North Branch } \\
\text { Pawtuxet }\end{array}$ & .138 & +1.358 & 1.022 & .474 & .167 & 0.685 & .409 & +.240 & +1.598 \\
\hline $\begin{array}{c}\text { South Branch } \\
\text { Pawtuxet }\end{array}$ & 1.747 & +3.072 & 3.358 & 1.461 & .520 & 4.479 & 1.731 & +3.372 & +6.444 \\
\hline $\begin{array}{c}\text { Northeastern } \\
\text { Pawtuxet }\end{array}$ & .306 & +17.86 & 12.60 & 5.563 & 1.754 & 21.12 & 1.335 & +11.61 & +29.47 \\
\hline
\end{tabular}




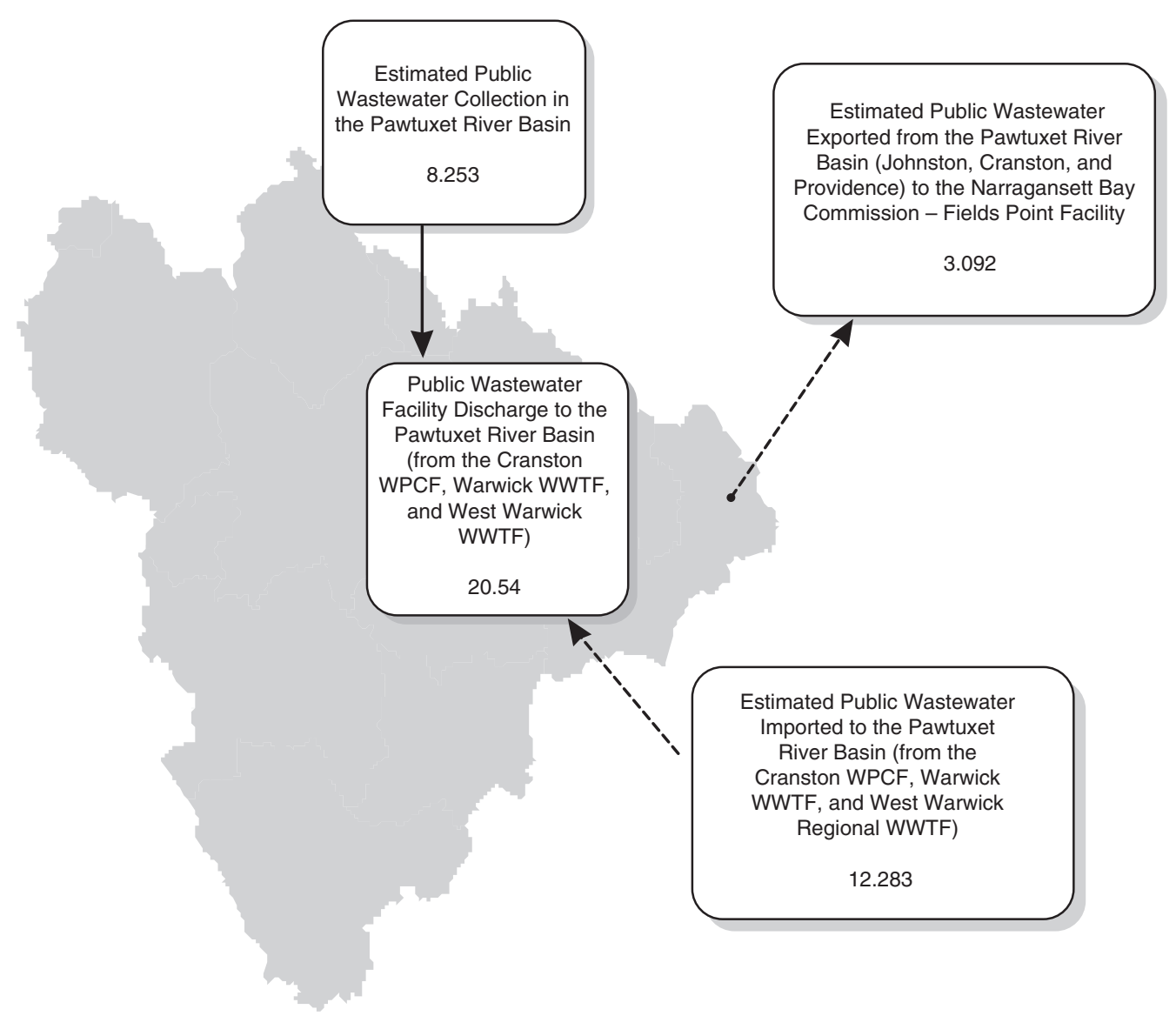

EXPLANATION

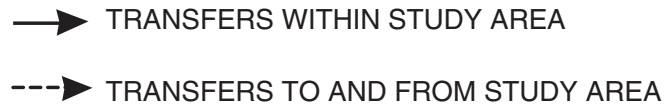

Figure 16. Estimated public wastewater collection, discharge, and estimated exports from the Pawtuxet River Basin, central Rhode Island, 1995-99. All rates in Mgal/d, million gallons per day. [WPCF, Water Pollution Control Facility; WWTF, Wastewater Treatment Facility] 
Table 19. Summary of estimated water withdrawals, imports, exports, use, consumptive use, and return flow in the Quinebaug River Basin, western Rhode Island, 1995-99.

[Consumptive use: A basin export. AG, agricultural; COM, commercial; DOM, domestic; IND, industrial; Mgal/d, million gallons per day; $<0.001$, values not included in town and subbasin totals; +, potable distribution and wastewater imported to subbasin and basin; -, potable distribution and wastewater exported from subbasin and basin; --, not applicable]

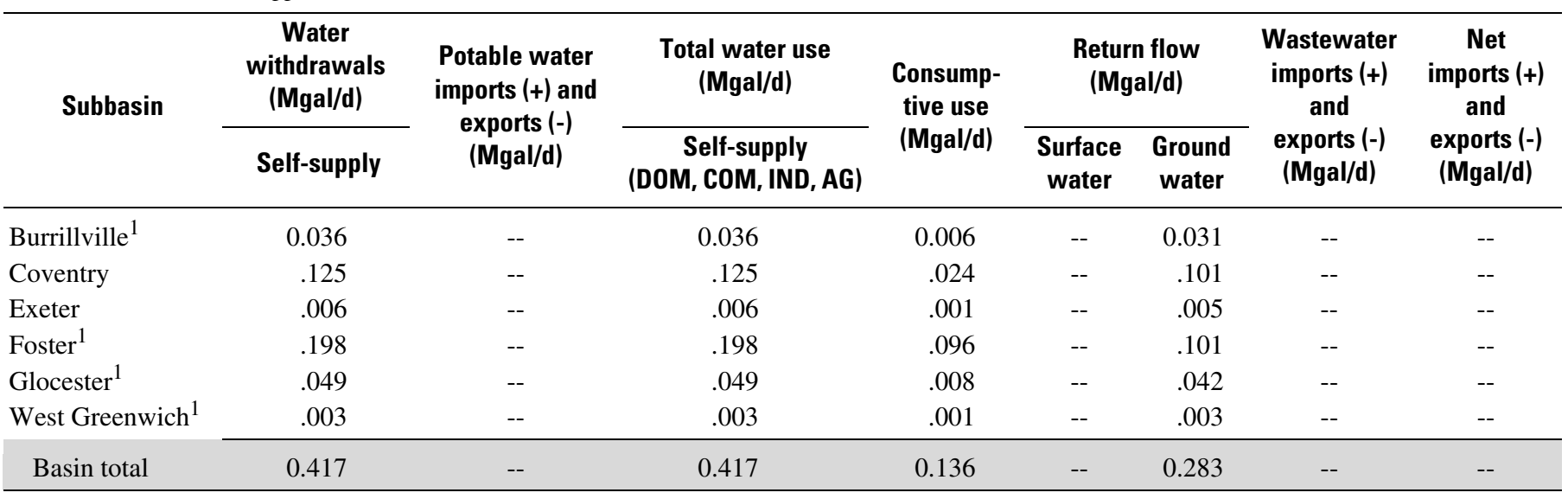

${ }^{1}$ Differences between the total water use and the sum of the consumptive use and the wastewater return flow are a result of rounding.

\section{Estimated Water Availability in the Summer}

During periods of little or no precipitation, streamflow is primarily sustained from surface-water storage (lakes and reservoirs) and from ground-water discharge; direct runoff is assumed to be negligible. Water withdrawals are often higher during the summer, and precipitation and ground-water discharge may be lower in the summer than the annual average. Therefore, it was important to estimate the amount of available water and to compare it to the withdrawals in the study area. Water-availability estimates that are made from base-flow calculations are conservative because actual streamflows generally are greater than base flow except during periods of no recharge from precipitation.

Because most of the study area is ungaged and records from stations in the study area are affected by ground-water withdrawals, estimates of available water had to be based on streamflows measured at stream-gaging stations in nearby basins. First, index stations were chosen whose upstream areal percentages of sand and gravel deposits and till deposits are similar to those in the study area. The Branch River at Forestdale stream-gaging station (01111500) was the index station used to determine water availability in the Scituate Reservoir Complex and North Branch Pawtuxet subbasins in the Pawtuxet River Basin and in the Quinebaug River Basin (fig. 8). The Nooseneck River at Nooseneck stream-gaging station (01115630) was the index station used to determine water availability in the South Branch Pawtuxet and Northeastern Pawtuxet subbasins of the Pawtuxet River Basin (table 20). Second, the hydrograph-separation application PART (Rutledge, 1993, 1998) was applied to the records for the two index stations to determine the 75th, 50th, and 25th percentiles of base flow for June, July, August, and September. The 75th, 50th, and 25th percentiles of base flow and these base flows minus the 7Q10 and $\mathrm{ABF}$ low flows (called the 7Q10 and ABF scenarios) were calculated (table 21). Third, these base flows were apportioned according to the contributions of base flow from sand and gravel deposits and of till deposits upstream of the two index stations to give base flows per unit area in $\mathrm{Mgal} / \mathrm{d} / \mathrm{mi}^{2}$. Contributions of base flow from stratified sand and gravel deposits and till deposits for the index stations used in this assessment were based on previous USGS work for five index stations in the Pawcatuck Basin (Wild and Nimiroski, 2004). The regression equation

$$
y=(0.4) e^{(x)(1.38)},
$$

where

$y=$ percentage of base-flow contribution from sand and gravel deposits at the index station, and

$x=$ sand and gravel area divided by the total drainage area at the index station,

was used to estimate base-flow contributions from sand and gravel deposits for the index stations, for which the flow contributions by deposit were unknown. The percentages of baseflow contributions from sand and gravel deposits were estimated to be 60 percent for the Branch River at Forestdale and 63 percent for the Nooseneck River at Nooseneck stations. The base flow for each deposit was divided by the area of each deposit upstream of each index station. The resulting values are estimates of the base flows per unit area in $\mathrm{Mgal} / \mathrm{d} / \mathrm{mi}^{2}$ for the sand and gravel and for the till areas upstream of the stations (table 22). Finally, the flow per unit area for each type of deposit at each index station was multiplied by the area of the same type 
of deposit in the study-area subbasins assigned to each index station. The gross yield from ground water for each subbasin was defined as the sum of the base-flow contributions from the two types of surficial deposits. The available water was defined for the same three scenarios as for the index stations. Ratios of water withdrawn to water available were calculated for each subbasin.

Table 20. U.S. Geological Survey stream-gaging stations and minimum streamflows used in the analysis of water availability in the Pawtuxet River Basin, central Rhode Island, and in the Quinebaug River Basin, western Rhode Island, $1995-99$.

[Stations are shown on fig. 8. Water years are from October to September and may differ from the period of record in the 2000 Water Data Report for Massachusetts and Rhode Island (Socolow and others, 2001). 7Q10, 7-day, 10-year low flow; ABF, Aquatic Base Flow, based on the median of the August monthly means; USGS, U.S. Geological Survey; Mgal/d, million gallons per day]

\begin{tabular}{|c|c|c|c|c|c|}
\hline \multirow{2}{*}{$\begin{array}{c}\text { USGS } \\
\text { stream-gaging } \\
\text { station number }\end{array}$} & \multirow[b]{2}{*}{ Station name } & \multirow[b]{2}{*}{$\begin{array}{c}\text { Drainage area } \\
\qquad\left(\mathrm{mi}^{2}\right)\end{array}$} & \multirow{2}{*}{$\begin{array}{c}\text { Annual } \\
\text { mean flow } \\
\text { (Mgal/d) } \\
\text { [calendar years] }\end{array}$} & \multicolumn{2}{|c|}{ Minimum flows (Mgal/d) } \\
\hline & & & & $\begin{array}{c}7010 \\
\text { [water years] }\end{array}$ & $\begin{array}{c}\mathrm{ABF} \\
\text { [calendar years] }\end{array}$ \\
\hline 01111500 & Branch River at Forestdale, RI & 91.2 & $\begin{array}{c}116.4 \\
{[1957-99]}\end{array}$ & $\begin{array}{c}7.694 \\
{[1957-99]}\end{array}$ & $\begin{array}{c}25.09 \\
{[1957-99]}\end{array}$ \\
\hline 01115630 & Nooseneck River at Nooseneck, RI & 8.28 & $\begin{array}{c}12.28 \\
{[1964-80]}\end{array}$ & $\begin{array}{c}.821 \\
{[1964-80]}\end{array}$ & $\begin{array}{c}2.910 \\
{[1964-80]}\end{array}$ \\
\hline
\end{tabular}

Table 21. Summer gross yields for the index stream-gaging stations used in the water-availability analysis in the Pawtuxet River Basin, central Rhode Island, and Quinebaug River Basin, western Rhode Island.

[7Q10, 7-day, 10-year low flow; ABF, Aquatic Base Flow, based on the median of the August monthly means; Mgal/d, million gallons per day; --, values less than zero and not used]

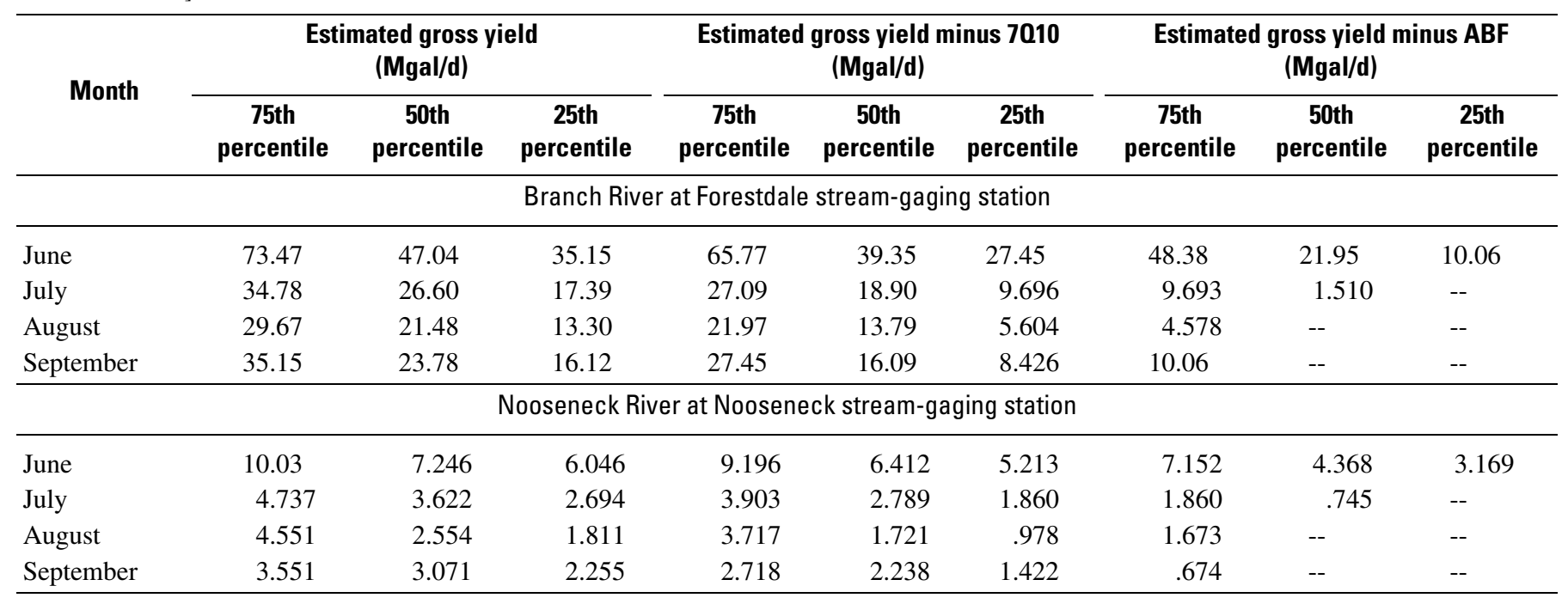


Table 22. Estimated gross yields; gross yields minus the 7-day, 10-year low flow; and gross yields minus the Aquatic Base Flow per unit area for the two index stations used to determine water availability for June, July, August, and September in the Pawtuxet River Basin, central Rhode Island, and the Quinebaug River Basin, western Rhode Island.

[Estimated gross yields based on base flow from the Branch River at Forestdale, RI, stream-gaging station for the period 1957-99. Estimated gross yields based on base flow from the Nooseneck River at Nooseneck, RI, stream-gaging station for the period 1964-80. 7Q10, 7-day, 10-year low flow; ABF, Aquatic Base Flow; Mgal/d, million gallons per day; --, values at station less than zero and not used]

\begin{tabular}{|c|c|c|c|c|c|c|c|c|c|}
\hline \multirow[t]{2}{*}{ Month } & \multicolumn{3}{|c|}{$\begin{array}{l}\text { Estimated gross yield } \\
\text { per unit area } \\
\left(\mathrm{Mgal} / \mathrm{d} / \mathrm{mi}^{2}\right)\end{array}$} & \multicolumn{3}{|c|}{$\begin{array}{l}\text { Estimated gross yield minus } 7010 \\
\text { per unit area } \\
\left(\text { Mgal } / \mathrm{d} / \mathrm{mi}^{2}\right)\end{array}$} & \multicolumn{3}{|c|}{$\begin{array}{c}\text { Estimated gross yield minus ABF } \\
\text { per unit area } \\
\left(\mathrm{Mgal} / \mathrm{d} / \mathrm{mi}^{2}\right)\end{array}$} \\
\hline & $\begin{array}{c}\text { 75th } \\
\text { percentile }\end{array}$ & $\begin{array}{c}\text { 50th } \\
\text { percentile }\end{array}$ & $\begin{array}{c}\text { 25th } \\
\text { percentile }\end{array}$ & $\begin{array}{c}\text { 75th } \\
\text { percentile }\end{array}$ & $\begin{array}{c}\text { 50th } \\
\text { percentile }\end{array}$ & $\begin{array}{c}\text { 25th } \\
\text { percentile }\end{array}$ & $\begin{array}{c}\text { 75th } \\
\text { percentile }\end{array}$ & $\begin{array}{c}\text { 50th } \\
\text { percentile }\end{array}$ & $\begin{array}{c}\text { 25th } \\
\text { percentile }\end{array}$ \\
\hline \multicolumn{10}{|c|}{ Branch River at Forestdale stream-gaging station } \\
\hline \multicolumn{10}{|c|}{ Yields from sand and gravel deposits estimated from base flow } \\
\hline June & 1.666 & 1.067 & 0.797 & 1.492 & 0.892 & 0.623 & 1.097 & 0.498 & 0.228 \\
\hline July & .789 & .603 & .541 & .614 & .429 & .220 & .220 & .034 & -- \\
\hline August & 673 & .487 & .302 & .498 & .313 & .127 & .104 & -- & -- \\
\hline September & .797 & .539 & .366 & .623 & .365 & .191 & .228 & -- & -- \\
\hline \multicolumn{10}{|c|}{ Yields from till deposits estimated from base flow } \\
\hline June & 0.454 & 0.291 & 0.217 & 0.406 & 0.243 & 0.170 & 0.299 & 0.136 & 0.062 \\
\hline July & .215 & .164 & .147 & .167 & .117 & .060 & .060 & .009 & -- \\
\hline August & .183 & .133 & .082 & .136 & .085 & .035 & .028 & -- & -- \\
\hline September & .217 & .147 & .100 & .170 & .099 & .052 & .062 & -- & -- \\
\hline \multicolumn{10}{|c|}{ Nooseneck River at Nooseneck stream-gaging station } \\
\hline \multicolumn{10}{|c|}{ Yields from sand and gravel deposits estimated from base flow } \\
\hline June & 2.180 & 1.575 & 1.314 & 1.999 & 1.394 & 1.133 & 1.555 & 0.950 & 0.689 \\
\hline July & 1.030 & .787 & .586 & .849 & 606 & .404 & .404 & .162 & -- \\
\hline August & .989 & .555 & .394 & .808 & .374 & .213 & .364 & -- & -- \\
\hline September & .772 & 668 & .490 & .591 & .486 & .309 & .146 & -- & -- \\
\hline \multicolumn{10}{|c|}{ Yields from till deposits estimated from base flow } \\
\hline June & 0.689 & 0.460 & 0.384 & 0.632 & 0.407 & 0.331 & 0.492 & 0.277 & 0.201 \\
\hline July & .326 & .230 & .171 & .268 & .177 & .118 & .128 & .047 & -- \\
\hline August & .313 & .162 & .115 & .256 & .109 & .062 & .115 & -- & -- \\
\hline September & .244 & .195 & .143 & .187 & .142 & .090 & .046 & -- & -- \\
\hline
\end{tabular}




\section{Pawtuxet River Basin}

In the Pawtuxet River Basin, water availability was calculated at the 75th, 50th, and 25th percentiles for the gross-yield scenario, the 7Q10 scenario, and the ABF scenario (table 23). The gross-yield value is equal to the estimated ground water available in the North Branch Pawtuxet, South Branch Pawtuxet, and Northeastern Pawtuxet subbasins. Estimated gross yields and gross yields for the 7Q10 scenarios were lower for August at the 50th and 25th percentiles. The water-availability rates by subbasin from sand and gravel deposits and till deposits are illustrated in figures 17 and 18, respectively. Although water availability was greater statewide in July than in August, more water was withdrawn in July than in August (table 24).

Basin withdrawal-to-availability ratios at the 75 th percentiles were highest in July for all three scenarios (table 25). Although the ratios were higher in July for the Scituate Reservoir Complex subbasin and in August for the North Branch Pawtuxet, South Branch Pawtuxet, and Northeastern Pawtuxet subbasins, the basinwide ratios for the gross yield and the 7Q10 scenarios at the 50th and 25th percentiles were higher in August. The ratios for June, July, August, and September at the 50th percentile for the 7Q10 scenario are illustrated for the subbasins in figure 19.

In the Scituate Reservoir Complex subbasin, the estimated ground-water availability for the four summer months illustrates the probable pattern of ground-water fluctuations within the subbasin (table 23). The outlet of the Scituate Reservoir at the Gainer Dam is also the surface-water outlet for the subbasin. The regulated outflow of $83 \mathrm{Mgal} / \mathrm{d}$ from the reservoir was assumed to include the ground-water component of base flow (table 23) within the subbasins tributary to the reservoir. Because no additional water is discharged into the North Branch Pawtuxet River within the subbasin below the dam, there is no variation in the available water caused by flows downstream of the dam. Thus, the total available water is equal to the regulated outflow from the dam. (In addition, $9 \mathrm{Mgal} / \mathrm{d}$ are required to be released to the North Branch Pawtuxet River (Weston, 1990); thus, the gross yield for the Scituate Reservoir Complex subbasin was $92 \mathrm{Mgal} / \mathrm{d}$.) Use that exceeds the safe yield during the summer months is offset by storage in the reservoir (table 25). This is the reason why the water used is most nearly equal to the available water (indicated by withdrawal-toavailability ratios closest to 1) in this subbasin. Because the total water available for each month was the same and the summer withdrawals (table 24) were lowest in September and highest in July (table 24), the ratios also were lowest in September and highest in July (table 25).

For the gross yield scenario at the 50th percentile, the water availability for the North Branch Pawtuxet subbasin was lowest in August and highest in June; because summer water withdrawals were lowest in September and highest in August (table 24), however, the withdrawal-to-availability ratio was lowest in June and highest in August (table 25). For the gross yield scenario at the 50th percentile, the water-availability results for the South Branch Pawtuxet subbasin and Northeast- ern Pawtuxet subbasin were lowest in August and highest in June; however, summer water withdrawals were lowest in September and highest in July (table 24), and the ratios were lowest in June and highest in August (table 25). For the ABF scenario at the 50th and 25th percentiles, the North Branch, South Branch, and Northeastern Pawtuxet subbasins have no water available in August and September (table 23).

\section{Quinebaug River Basin}

In the Quinebaug River Basin, water availability in the subbasin for the gross yield at the 50th percentile was lowest in August and highest in June (table 26); however, summer water withdrawals were lowest in September and highest in July (table 27), and the withdrawal-to-availability ratios were lowest in June and highest in August (table 28). For the ABF scenario, the basin has no water available at the 50th percentile in August and September, and at the 25th percentile in July, August, and September (table 26).

\section{Water Budget}

The water budget encompasses the hydrologic cycle and the water-use components, both of which produce inflows and outflows to the basin. In a basin water budget, inflow minus outflow equals the change in storage. For this investigation, calculation of the long-term water budget was based on the assumption that inflow equals outflow; the change in water storage from surface-water bodies and aquifers is considered to be negligible. Inflows to the basin include precipitation, streamflow from upstream subbasins, ground-water inflow, and return flow (from septic systems, RIPDES, and WWTFs). Outflows from the basin include evapotranspiration, streamflow out of the subbasins, water withdrawals (for public supply and self-supply domestic, commercial, industrial, and agricultural uses), and ground-water underflow. The water budget components are summarized in table 29 for the Pawtuxet River Basin and in table 30 for the Quinebaug River Basin.

\section{Pawtuxet River Basin}

Since 1917, ProvWater has collected precipitation data at a network of stations within the Scituate Reservoir Complex subbasin for management purposes, and these data were used to calculate the water budget for 1941 through 1999. The average precipitation for the Scituate Reservoir Complex subbasin (Providence Water Supply Board, written commun., 2000) (estimated to be $2.429 \mathrm{Mgal} / \mathrm{d} / \mathrm{mi}^{2}$ ) was used for the Scituate Reservoir Complex and North Branch Pawtuxet subbasin water budgets. The average precipitation at the Kingston climatological station (National Oceanic and Atmospheric Administration, 2000) (estimated to be $2.280 \mathrm{Mgal} / \mathrm{d} / \mathrm{mi}^{2}$ ) was used for the South Branch Pawtuxet and the Northeastern Pawtuxet subba- 
sin water budgets. The North Branch Pawtuxet and the Northeastern Pawtuxet subbasins have surface-water inflow from upstream subbasins. Data on ground-water inflow were not available for this study. Return flow includes the average rate of disposal from 1995 through 1999 from septic systems, RIPDES, and wastewater-treatment facilities. Evapotranspiration estimates were calculated as the difference between the mean annual precipitation per unit area and the mean annual flow per unit area at each subbasin's assigned index station (table 29). The outflow of streamflow from each subbasin was estimated as sum of the inflows minus withdrawals minus evapotranspiration.

The total water budget for the Pawtuxet River Basin was 574.7 Mgal/d. The estimated inflows from precipitation and return flow were 94.7 and 5.3 percent of the total budget, and the estimated outflows from evapotranspiration, streamflow, and water withdrawals were $46.3,40.8$, and 12.9 percent, respectively. Forty percent of this water is accounted for in the Scituate Reservoir Complex subbasin.

\section{Quinebaug River Basin}

The average precipitation for the Scituate Reservoir Complex (2.429 Mgal/d/mi ${ }^{2}$ ) (Providence Water Supply Board, written commun., 2000) was used to calculate the water budget for the Quinebaug River Basin for 1941 through 1999. Data for ground-water inflow were unavailable for this study. Return flow is the average rate of disposal from 1995 through 1999 from septic systems. Evapotranspiration estimates were calculated as the difference between the mean annual precipitation per unit area and the mean annual flow per unit area at each subbasin's assigned index station (table 30). The outflow from the basin was estimated as the sum of the inflows minus the withdrawals minus evapotranspiration.

The total water budget for the Quinebaug River Basin study area was $148.4 \mathrm{Mgal} / \mathrm{d}$. The estimated inflows from precipitation and return flow were 99.8 and 0.2 percent of the total budget, respectively; and the estimated outflows from evapotranspiration, streamflow, and water withdrawals were 48.6, 51.2, and 0.2 percent, respectively. 


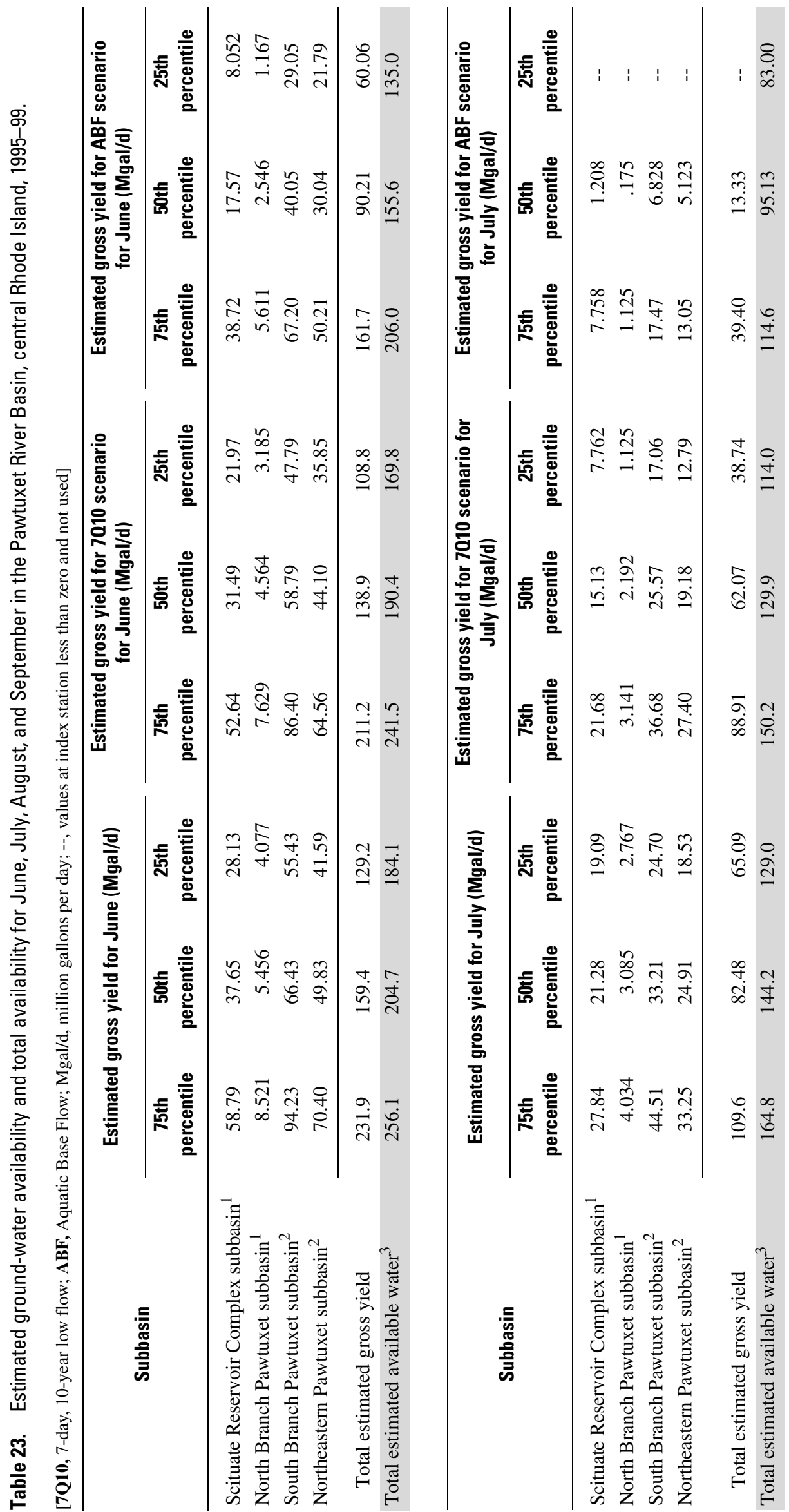




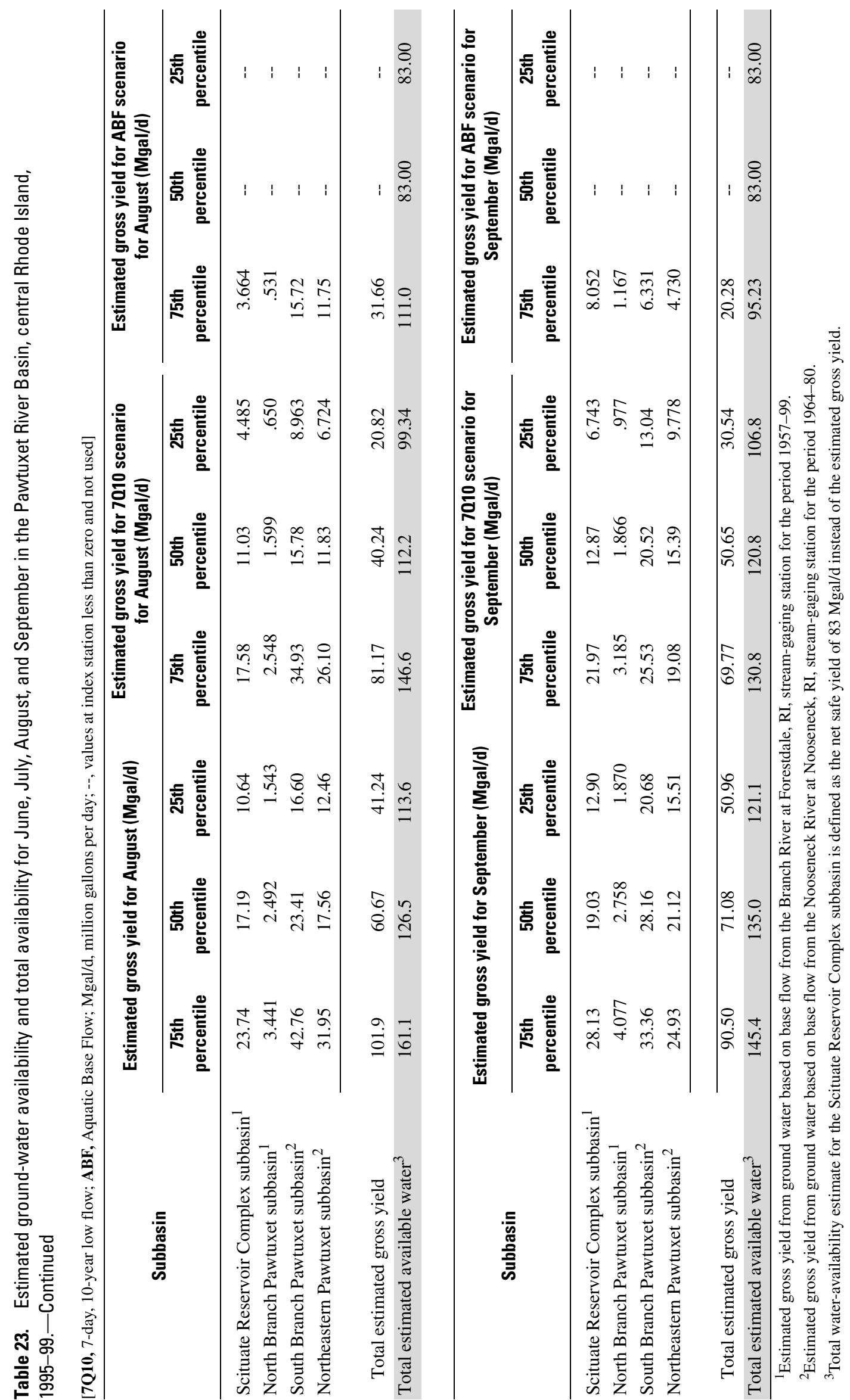



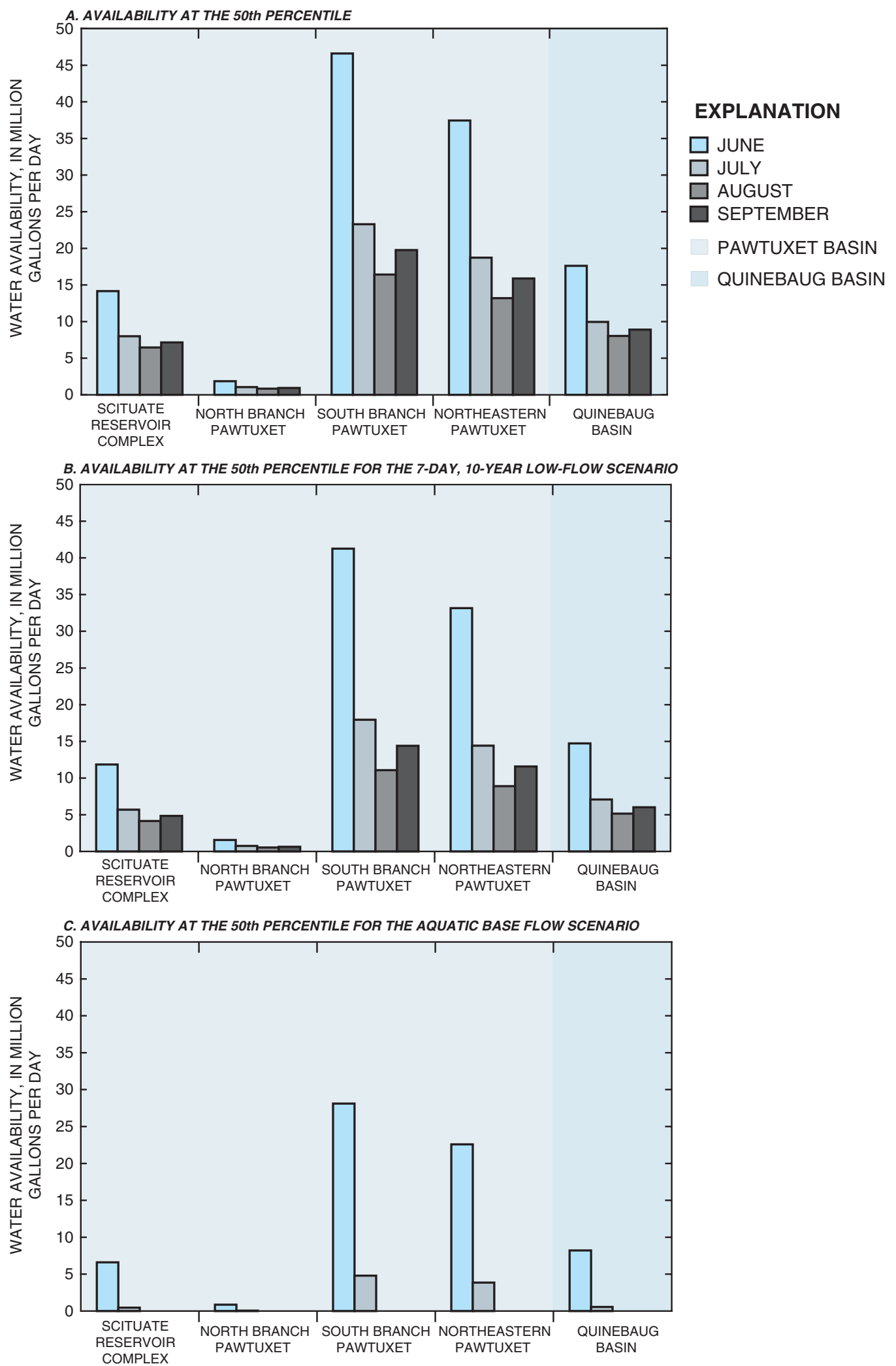

Figure 17. Estimated water availability for June, July, August, and September from sand and gravel deposits for the subbasins in the Pawtuxet and Quinebaug River Basins, central and western Rhode Island, for the $A$, 50th percentile; $B, 50$ th percentile for the 7-day, 10-year low-flow scenario; and $C$, 50th percentile for the Aquatic Base Flow scenario. 


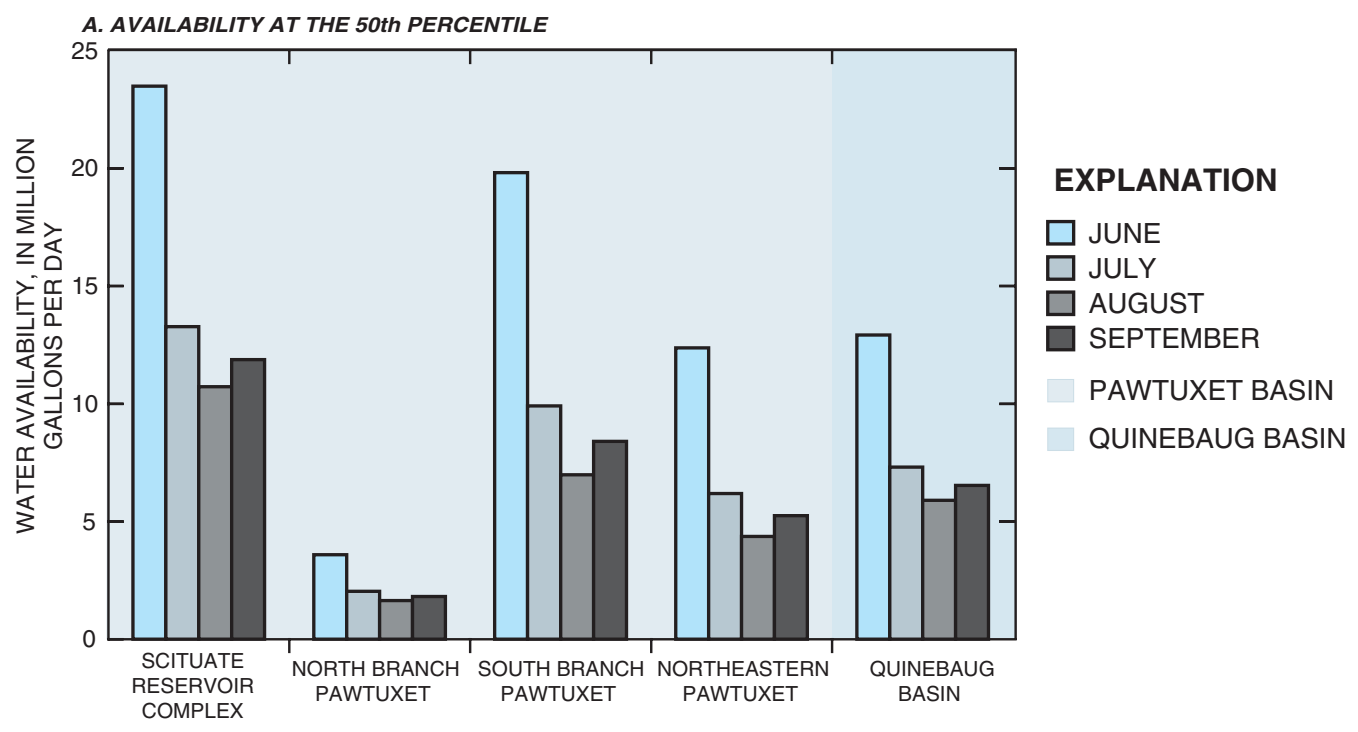

B. AVAILABILITY AT THE 50Th PERCENTILE FOR THE 7-DAY, 10-YEAR LOW-FLOW SCENARIO
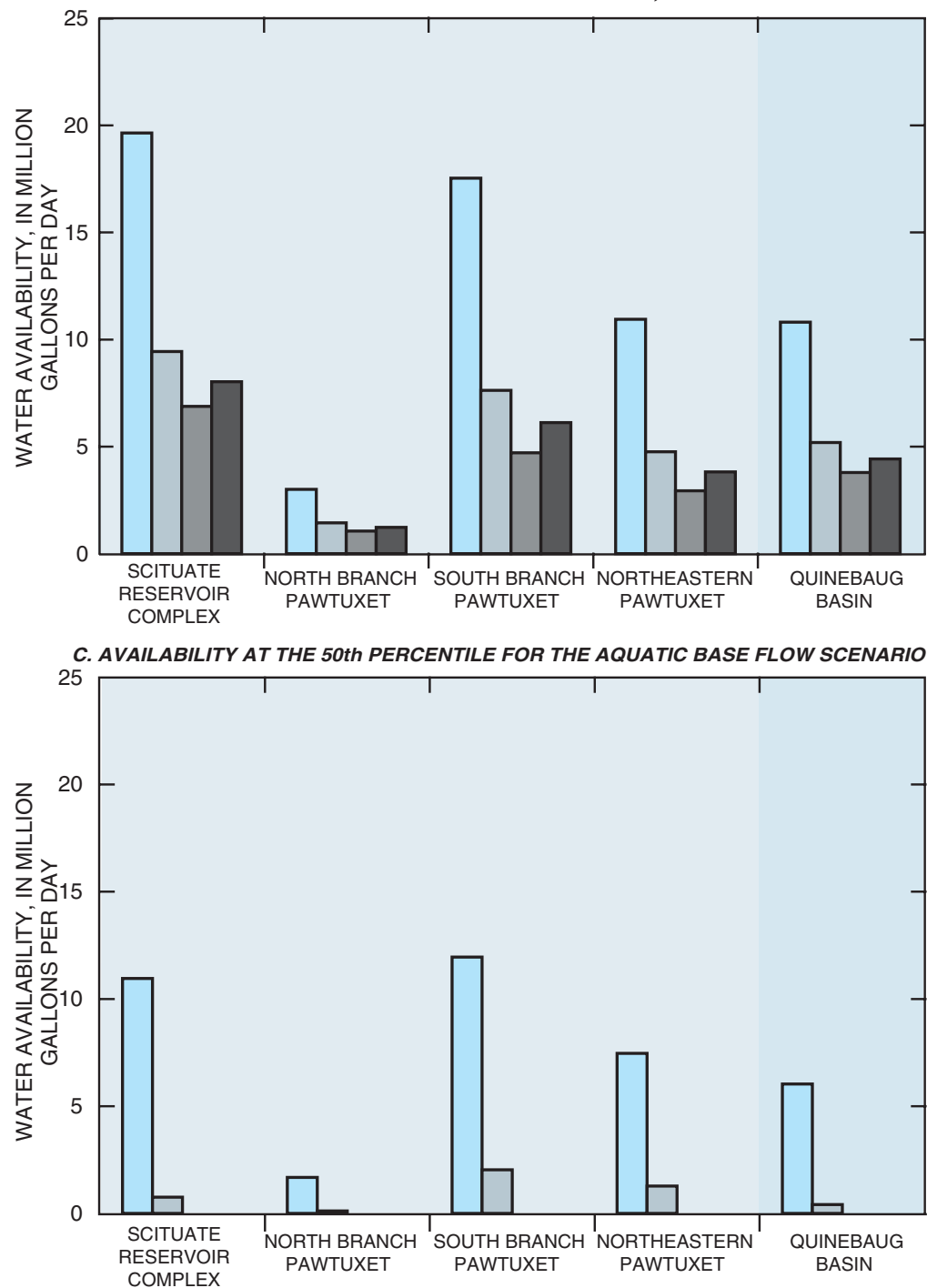

Figure 18. Estimated water availability for June, July, August, and September from till deposits for the subbasins in the Pawtuxet and Quinebaug River Basins, central and western Rhode Island, for the $A$, 50th percentile; $B$, 50th percentile for the 7-day, 10-year low-flow scenario; and $C$, 50th percentile for the Aquatic Base Flow scenario. 

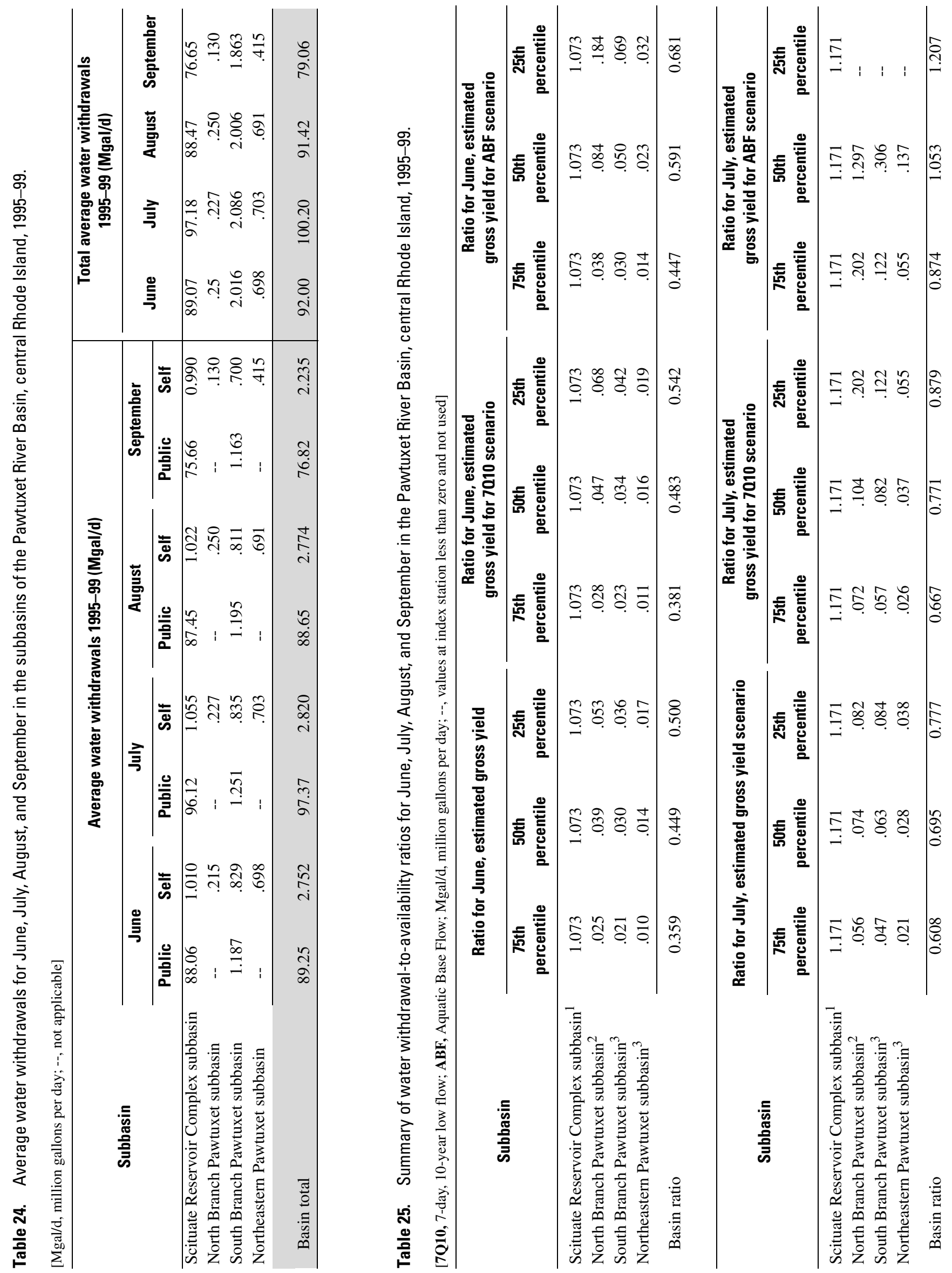


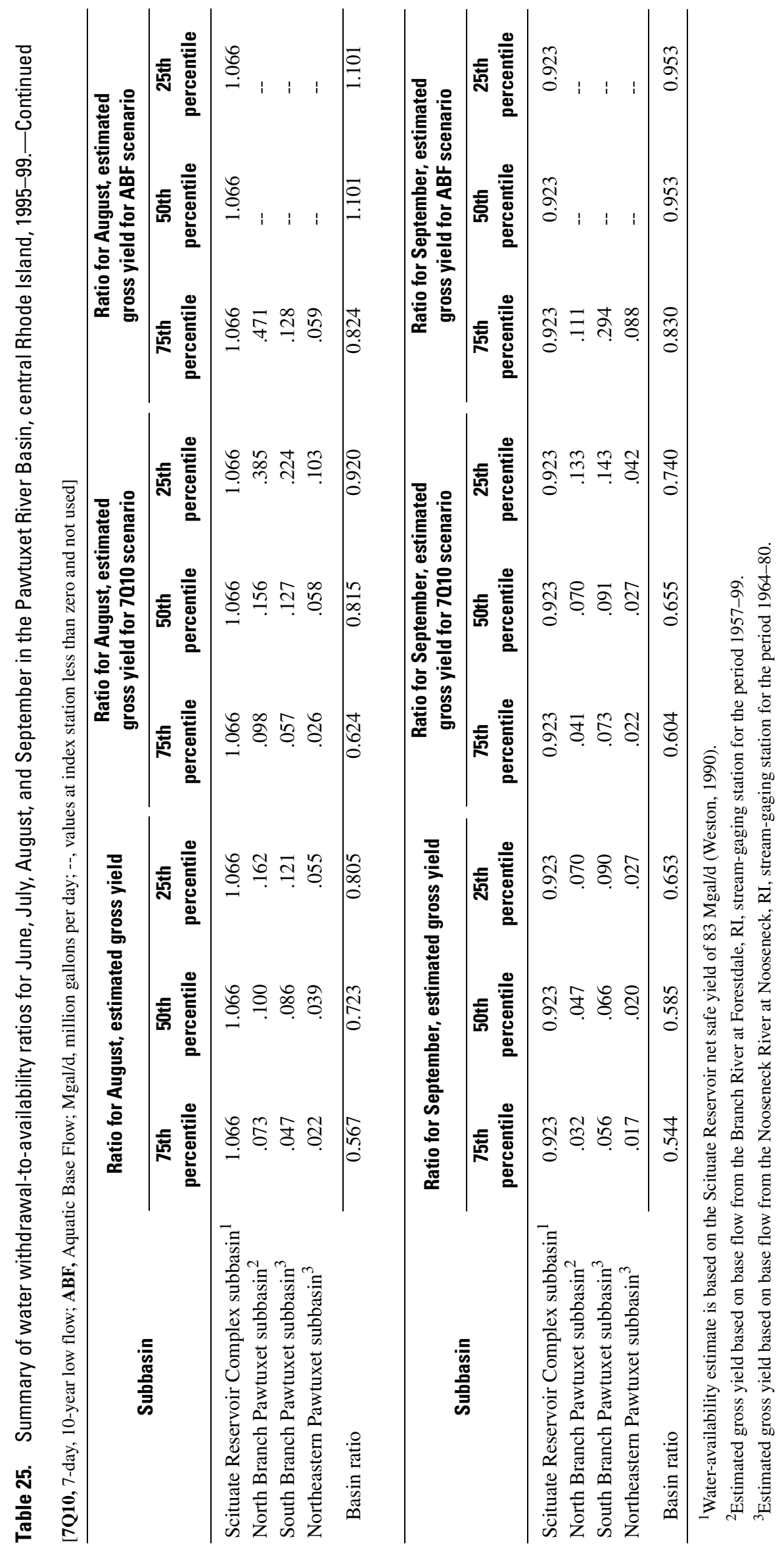


A. JUNE WITHDRAWAL-TO-AVAILABILITY RATIOS

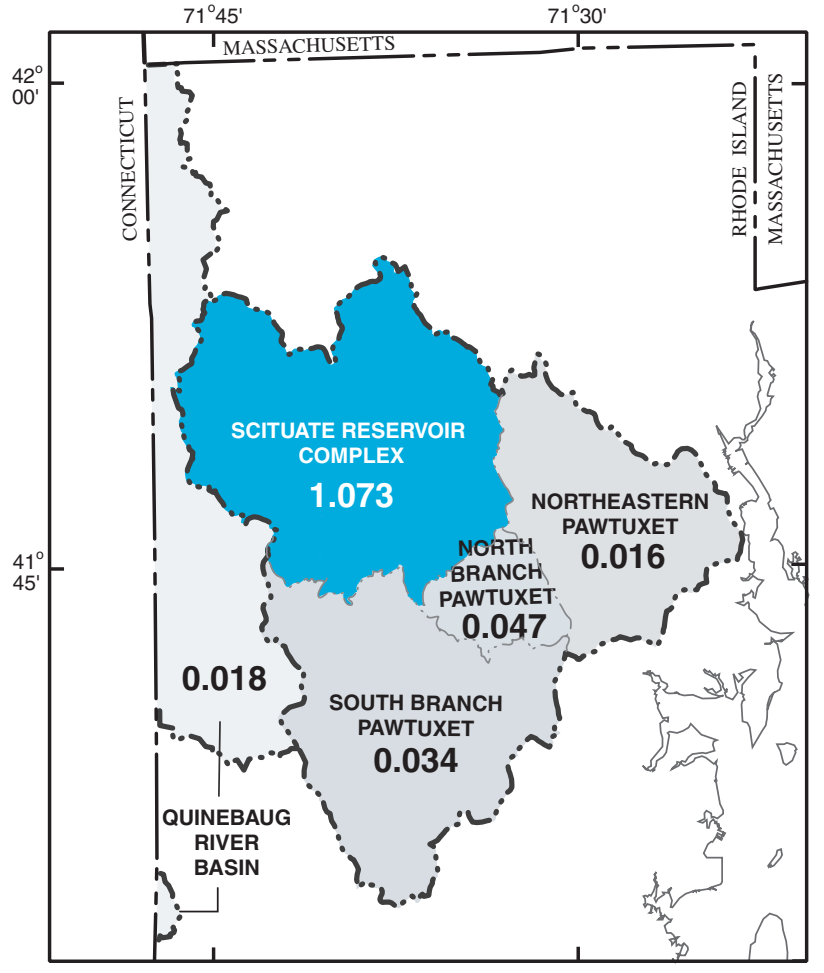

C. AUGUST WITHDRAWAL-TO-AVAILABILITY RATIOS

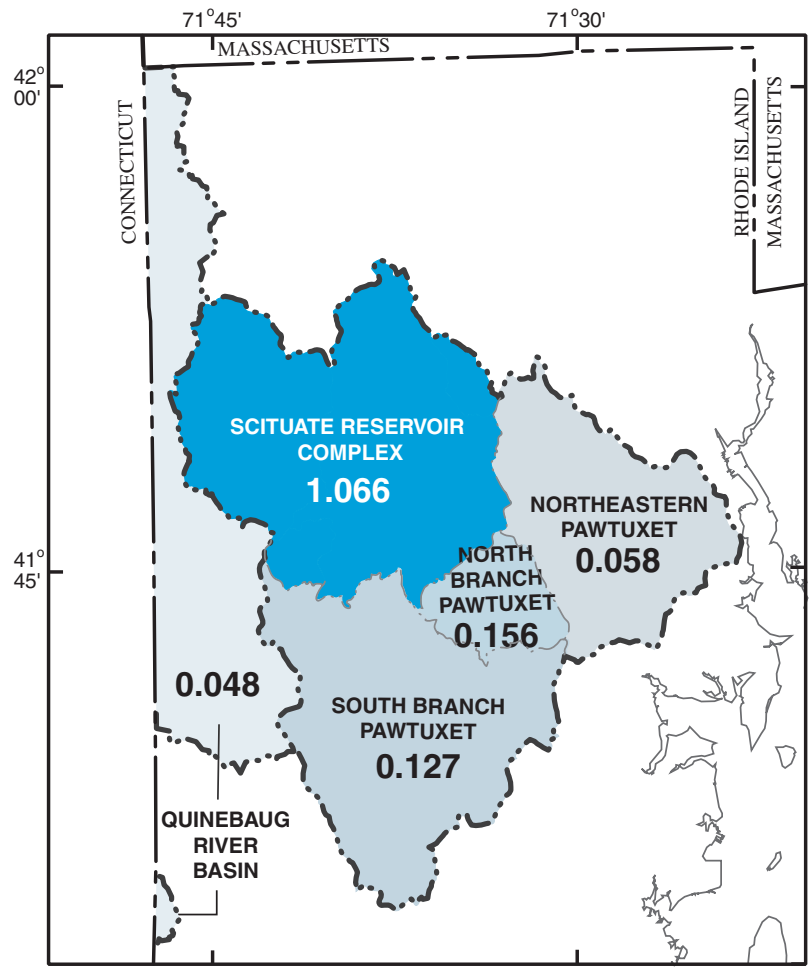

Base from U.S. Geological Survey and Rhode Island Geographic Information System digital data, 1:24,000, Lambert conformal conic projection,

1983 North American datum
B. JULY WITHDRAWAL-TO-AVAILABILITY RATIOS

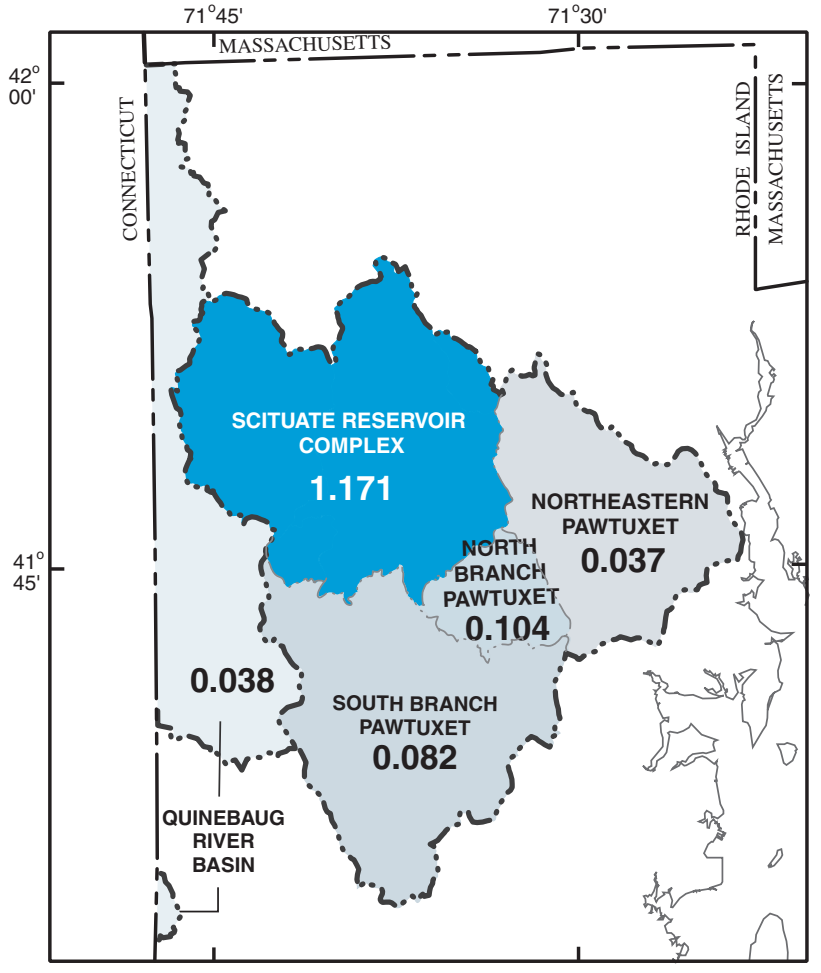

D. SEPTEMBER WITHDRAWAL-TO-AVAILABILITY RATIOS

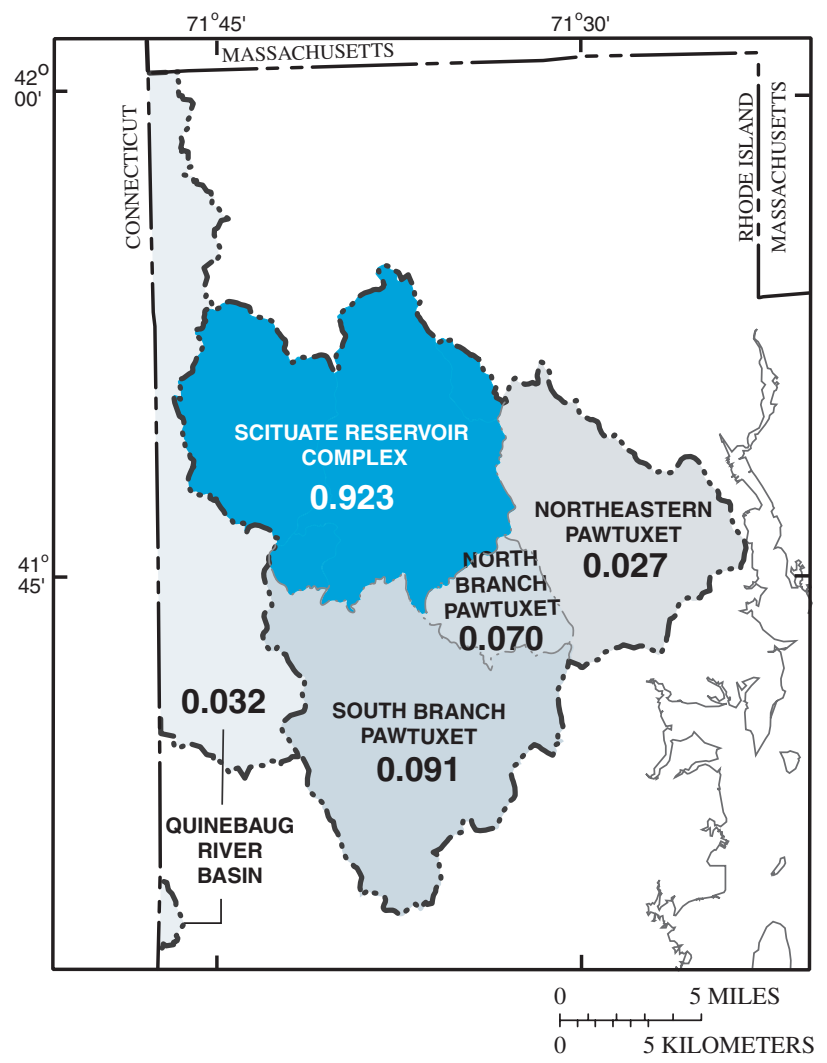

Figure 19. The water withdrawal-to-availability ratios in $A$, June; $B$, July; $C$, August; and $D$, September for the subbasins in the Pawtuxet and Quinebaug River Basins, central and western Rhode Island, at the 50th percentile for the 7-day, 10-year low-flow scenario. 
Table 26. Estimated gross yield; gross yield for the 7-day, 10-year low-flow scenario; and gross yield for the Aquatic Base Flow scenario for June, July, August, and September in the Quinebaug River Basin, western Rhode Island.

[Estimated gross yields calculated from base flow at the Branch River at Forestdale, RI, stream-gaging station, 1957-99. 7Q10, 7-day, 10-year low flow; ABF, Aquatic Base Flow; Mgal/d, million gallons per day; --, values at index station less than zero and not used]

\begin{tabular}{|c|c|c|c|c|c|c|c|c|c|}
\hline \multirow{2}{*}{ Month } & \multicolumn{3}{|c|}{ Estimated gross yield (Mgal/d) } & \multicolumn{3}{|c|}{$\begin{array}{l}\text { Estimated gross yield for the } 7010 \\
\text { scenario (Mgal/d) }\end{array}$} & \multicolumn{3}{|c|}{$\begin{array}{l}\text { Estimated gross yield for the ABF } \\
\text { scenario (Mgal/d) }\end{array}$} \\
\hline & $\begin{array}{c}\text { 75th } \\
\text { percentile }\end{array}$ & $\begin{array}{c}\text { 50th } \\
\text { percentile }\end{array}$ & $\begin{array}{c}\text { 25th } \\
\text { percentile }\end{array}$ & $\begin{array}{c}\text { 75th } \\
\text { percentile }\end{array}$ & $\begin{array}{c}\text { 50th } \\
\text { percentile }\end{array}$ & $\begin{array}{c}\text { 25th } \\
\text { percentile }\end{array}$ & $\begin{array}{c}\text { 75th } \\
\text { percentile }\end{array}$ & $\begin{array}{c}\text { 50th } \\
\text { percentile }\end{array}$ & $\begin{array}{c}\text { 25th } \\
\text { percentile }\end{array}$ \\
\hline \multicolumn{10}{|c|}{ Estimated yields from sand and gravel deposits } \\
\hline June & 27.50 & 17.61 & 13.16 & 24.62 & 14.73 & 10.28 & 18.11 & 8.216 & 3.765 \\
\hline September & 13.156 & 8.901 & 6.033 & 10.28 & 6.021 & 3.153 & 3.765 & -- & -- \\
\hline \multicolumn{10}{|c|}{ Estimated yields from till deposits } \\
\hline June & 20.18 & 12.92 & 9.656 & 18.07 & 10.81 & 7.542 & 13.29 & 6.031 & 2.764 \\
\hline July & 9.555 & 7.306 & 6.554 & 7.441 & 5.192 & 2.664 & 2.663 & .415 & -- \\
\hline June & 47.68 & 30.53 & 22.81 & 42.69 & 25.54 & 17.82 & 31.40 & 14.25 & 6.529 \\
\hline July & 22.57 & 17.26 & 15.49 & 17.58 & 12.27 & 6.295 & 6.291 & .980 & -- \\
\hline August & 19.25 & 13.94 & 8.632 & 14.26 & 8.947 & 3.637 & 2.971 & -- & -- \\
\hline September & 22.81 & 15.43 & 10.46 & 17.82 & 10.44 & 5.468 & 6.529 & -- & -- \\
\hline
\end{tabular}

Table 27. Average water withdrawals for June, July, August, and September in the towns in the Quinebaug River Basin, western Rhode Island, 1995-99.

[Mgal/d, million gallons per day]

\begin{tabular}{lrrrr}
\hline \multirow{2}{*}{ Town } & \multicolumn{4}{c}{ Average water withdrawals 1995-99 (Mgal/d) } \\
\cline { 2 - 5 } & \multicolumn{1}{c}{ June } & \multicolumn{1}{c}{ July } & August & September \\
\hline Burrillville & 0.037 & 0.037 & 0.037 & 0.036 \\
Coventry & .147 & .153 & .124 & .120 \\
Exeter & .006 & .006 & .006 & .006 \\
Foster & .216 & .216 & .211 & .120 \\
Glocester & .052 & .048 & .051 & .048 \\
West Greenwich & .003 & .003 & .003 & .003 \\
\cline { 2 - 5 }$\quad$ Basin total & 0.461 & 0.463 & 0.432 & 0.333 \\
\hline
\end{tabular}


Table 28. Summary of water withdrawal-to-availability ratios for June, July, August, and September in the Quinebaug River Basin, western Rhode Island, 1995-99.

[Estimated gross yields calculated from base flow at the Branch River at Forestdale, RI, stream-gaging station for 1957-99. 7Q10, 7-day, 10-year low flow; ABF, Aquatic Base Flow; Mgal/d, million gallons per day; --, values at index station less than zero and not used]

\begin{tabular}{|c|c|c|c|c|c|c|c|c|c|}
\hline \multirow{2}{*}{ Month } & \multicolumn{3}{|c|}{ Ratio for the estimated gross yield } & \multicolumn{3}{|c|}{$\begin{array}{l}\text { Ratio for the estimated gross } \\
\text { yield for the } 7010 \text { scenario }\end{array}$} & \multicolumn{3}{|c|}{$\begin{array}{l}\text { Ratio for the estimated gross } \\
\text { yield for the ABF scenario }\end{array}$} \\
\hline & $\begin{array}{c}\text { 75th } \\
\text { percentile }\end{array}$ & $\begin{array}{c}\text { 50th } \\
\text { percentile }\end{array}$ & $\begin{array}{c}\text { 25th } \\
\text { percentile }\end{array}$ & $\begin{array}{c}\text { 75th } \\
\text { percentile }\end{array}$ & $\begin{array}{c}\text { 50th } \\
\text { percentile }\end{array}$ & $\begin{array}{c}\text { 25th } \\
\text { percentile }\end{array}$ & $\begin{array}{c}\text { 75th } \\
\text { percentile }\end{array}$ & $\begin{array}{c}\text { 50th } \\
\text { percentile }\end{array}$ & $\begin{array}{c}\text { 25th } \\
\text { percentile }\end{array}$ \\
\hline June & 0.010 & 0.015 & 0.020 & 0.011 & 0.018 & 0.026 & 0.015 & 0.032 & 0.071 \\
\hline July & .021 & .027 & .030 & .026 & .038 & .074 & .074 & .472 & -- \\
\hline
\end{tabular}

Table 29. Average water budget by subbasin for the Pawtuxet River Basin, central Rhode Island.

[Shaded areas are basin totals. RIPDES, Rhode Island Pollutant Discharge Elimination System; in/yr, inches per year; Mgal/d, million gallons per day; $\mathrm{Mgal} / \mathrm{d} / \mathrm{mi}^{2}$, million gallons per day per square mile; $\mathrm{mi}^{2}$, square mile; --, not applicable]

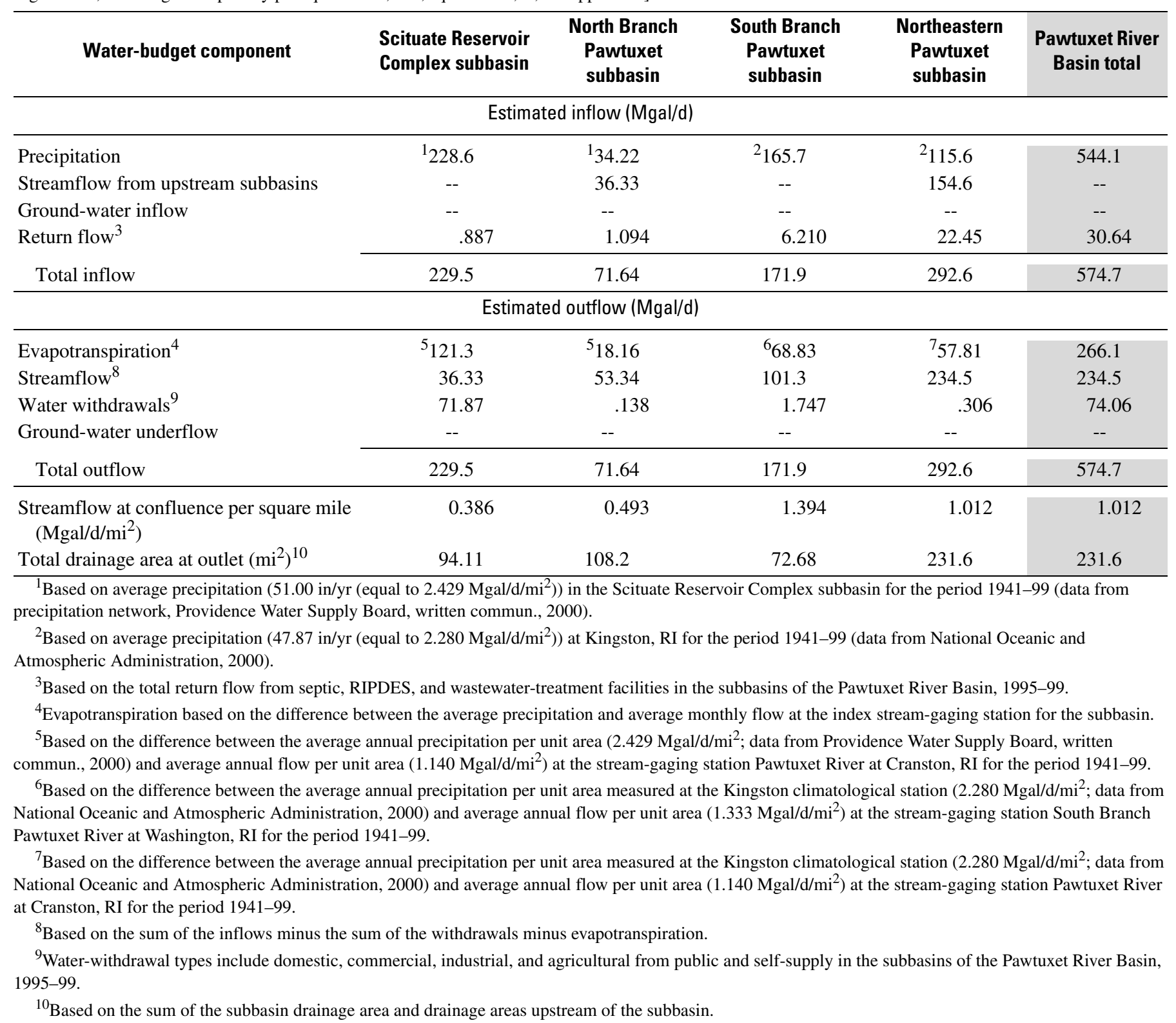


Table 30. Average water budget for the Quinebaug River Basin, western Rhode Island.

[Shaded areas are basin totals. in/yr, inches per year; Mgal/d, million gallons per day; Mgal $/ \mathrm{d} / \mathrm{mi}^{2}$, million gallons per day per square mile; $\mathrm{mi}^{2}$, square miles; --, not applicable]

\section{Water-budget component}

Estimated inflow (Mgal/d)

Precipitation $^{1}$

Streamflow from upstream subbasins

Ground-water inflow

Return flow ${ }^{2}$

Total inflow

Estimated outflow (Mgal/d)

Evapotranspiration $^{3}$

Streamflow 4

Water withdrawals ${ }^{5}$

Ground-water underflow

Total outflow

Streamflow per square mile $\left(\mathrm{Mgal} / \mathrm{d} / \mathrm{mi}^{2}\right)$

Total drainage area at outlet $\left(\mathrm{mi}^{2}\right)^{6}$

${ }^{1}$ Based on average precipitation (51.00 in/yr) in the Scituate Reservoir Complex subbasin for the period 1941-99 (data from precipitation network, Providence Water Supply Board, written commun., 2000).

${ }^{2}$ Based on the total return flow from septic in the Quinebaug River Basin, 1995-99.

${ }^{3}$ Evapotranspiration is based on the difference between the average annual precipitation per unit area $\left(2.429 \mathrm{Mgal} / \mathrm{d} / \mathrm{mi}^{2}\right.$; data from precipitation network, Providence Water Supply Board, written commun., 2000) and average annual flow per unit area $\left(1.247 \mathrm{Mgal} / \mathrm{d} / \mathrm{mi}^{2}\right)$ at the stream-gaging station Branch River at Forestdale, RI, for the period 1941-99.

${ }^{4}$ Based on the sum of the inflows minus the sum of the withdrawals minus evapotranspiration.

${ }^{5}$ Water-withdrawal types include domestic, commercial, industrial, and agricultural from public and self-supply in the Quinebaug River Basin, 1995-99.

${ }^{6} \mathrm{Basin}$ outlet is defined as the political boundary with Connecticut for this study.

\section{Summary}

During a drought in 1999, ground-water levels and streamflows dropped below long-term averages throughout Rhode Island. Consequently, the State of Rhode Island became concerned about water availability, and further investigation was needed to assess water use and availability throughout the state. The U.S. Geological Survey (USGS), in cooperation with the Rhode Island Water Resources Board (RIWRB), began a series of water-use and availability investigations for 1995-99 to describe the relations between water-use and hydrologic-cycle components for both surface and ground water during periods of little to no recharge. The investigations for the Pawtuxet (area $231.6 \mathrm{mi}^{2}$ ) and Quinebaug (area $60.97 \mathrm{mi}^{2}$ ) River Basins are two of a planned series of nine being completed for basins in Rhode Island.

In addition to water use and availability, basin water budgets were calculated to summarize the components of the hydrologic cycle and selected water-use components for 1941 through 1999. Data were collected for the subbasins in this study by using the spatial delineation derived from the surfacewater-system drainage areas. The New England Water-Use Data System was used to organize and retrieve data for water withdrawals, users by category, and return flows for the study period.

In the Pawtuxet River Basin, the Scituate Reservoir was the primary source of water withdrawn by public suppliers (about 95 percent of the average annual water withdrawals during the study period). The only major public water supplier in the Scituate Reservoir Complex subbasin is Providence Water Supply Board, which supplies almost all of the other basins in Rhode Island, including the Blackstone, the Moshassuck, the Woonasquatucket, the Narragansett Bay, and the Westport Basins. Only the Quinebaug, the Pawcatuck, and the South Coastal Basins are not supplied by the Scituate Reservoir. In the Quinebaug River Basin, ground water is the sole source for the one minor public supplier and all the domestic users, which together accounted for about 89 percent of the average annual water withdrawals during the study period.

In the Pawtuxet River Basin, two major water suppliers withdrew a total of $71.86 \mathrm{Mgal} / \mathrm{d}$ from ground and surface water (which includes the Scituate Reservoir). Estimated water withdrawals from minor water suppliers were $0.026 \mathrm{Mgal} / \mathrm{d}$ in the Pawtuxet River Basin and $0.003 \mathrm{Mgal} / \mathrm{d}$ in the Quinebaug River Basin. About $35.98 \mathrm{Mgal} / \mathrm{d}$ of potable water from major publicsupply withdrawals was exported from the Pawtuxet River Basin to other basins in Rhode Island. Self-supply domestic, industrial, commercial, and agricultural withdrawals from the basin totaled 2.173 Mgal/d in the Pawtuxet River Basin and $0.360 \mathrm{Mgal} / \mathrm{d}$ in the Quinebaug River Basin. Total water use was $18.07 \mathrm{Mgal} / \mathrm{d}$ in the Pawtuxet River Basin and was 0.363 $\mathrm{Mgal} / \mathrm{d}$ in the Quinebaug River Basin. The total return flow was $30.64 \mathrm{Mgal} / \mathrm{d}$ in the Pawtuxet River Basin, which included effluent from permitted facilities and water users on self-disposal; of the total, about $12.28 \mathrm{Mgal} / \mathrm{d}$ of wastewater was imported to the Pawtuxet River Basin from other basins in Rhode Island. Return flow in the Quinebaug River Basin was $0.283 \mathrm{Mgal} / \mathrm{d}$.

Ground-water availability was estimated from output from the PART program, a computerized hydrograph-separation application. To determine water availability at the 75th, 50th, and 25th percentiles, two index stream-gaging stations in nearby basins were used for three scenarios: the total base-flow scenario; the base flow for the 7-day, 10-year (7Q10) low-flow scenario; and the base flow for the Aquatic Base Flow (ABF) scenario. A regression equation was used to estimate unknown base-flow contributions from sand and gravel deposits at the two stations. The water available at the Branch River at Forestdale, Rhode Island, stream-gaging station was lowest in August 
at the 75 th, 50th, and 25 th percentiles $(29.67,21.48$, and $13.30 \mathrm{Mgal} / \mathrm{d}$, respectively). The water available at the Nooseneck River at Nooseneck, Rhode Island, stream-gaging station was lowest in September at the 75 th percentile $(3.551 \mathrm{Mgal} / \mathrm{d})$ and in August at the 50th and 25th percentiles (2.554 and $1.811 \mathrm{Mgal} / \mathrm{d})$.

Base-flow contributions at the stations estimated from sand and gravel deposits and from till deposits (surficial deposits) were divided by the respective drainage areas for the two types of deposits to give ratios of flow per unit area. The ratios were multiplied by the areas of the sand and gravel deposits and till deposits in the subbasins. Finally, the total flows from the sand and gravel deposits and till deposits in the subbasin were added to obtain the gross yield. In the Pawtuxet River Basin, the gross yield from ground water was assumed to be part of the net safe yield of $83 \mathrm{Mgal} / \mathrm{d}$ from the Scituate Reservoir. This amount was defined as the total water available for the Scituate Reservoir Complex subbasin.

Because water withdrawals and use are greater during the summer than other times of the year, water availability at the 75th, 50th, and 25th percentiles in June, July, August, and September was calculated and compared to water withdrawals in the basin and subbasins. The closer the withdrawals are to the estimated water available because the net water available decreases, the closer the resulting ratio is to one. For the study period, withdrawals in July were higher than withdrawals in the other summer months in both basins. For the Pawtuxet River Basin, the ratios were higher in August than in the other three summer months for all three scenarios at the 50th percentile. The ratios were close to 1 for the Scituate Reservoir Complex subbasin for all scenarios in all of the summer months because of the fixed safe yield from the Scituate Reservoir. For the Quinebaug River Basin, the ratios were also higher in August for all three scenarios, but because of reduced water availability, were generally lower than the total basin ratios for the Pawtuxet River Basin.

For estimating the water budget, it was assumed that inflow equals outflow. The water budgets of the Pawtuxet River Basin and the Rhode Island part of the Quinebaug River Basin were $574.9 \mathrm{Mgal} / \mathrm{d}$ and $148.4 \mathrm{Mgal} / \mathrm{d}$, respectively. The estimated inflows from precipitation and return flow were 94.7 and 5.3 percent, respectively, of the total budget for the Pawtuxet River Basin. The estimated inflow from precipitation was 99.8 percent of the total budget for the Quinebaug River Basin. The estimated outflows in the Pawtuxet River Basin from evapotranspiration, streamflow, and water withdrawals were 46.3 , 40.8, and 12.9 percent of the budget, respectively. The estimated outflows in the Quinebaug River Basin from evapotranspiration and streamflow were 48.6 and 51.2 percent of the budget, respectively.

\section{Acknowledgments}

Original water-use withdrawal and discharge data were collected from the public-supply districts, the RIDEM Office of
Water Resources, individual wastewater-discharge facilities, and the Rhode Island Water Resources Board. The authors thank the following individuals for assisting in the data-collection process: George Corrente, Johnston Water District; Timothy Brown, Kent County Water Authority; Richard Blodgett and Peter LePage, Providence Water Supply Board; Daniel O'Rourke and Robert Desaulniers, Warwick Water Department; Christian Bratina, Cranston Water Pollution Control Facility; Carmine Goneconte, Narragansett Bay Commission-Fields Point; Joel Burke, Warwick Wastewater Facility; Michael Roberts, West Warwick Wastewater Facility; Aaron Mello, RIDEM Office of Water Resources; Clay Commons, Rhode Island Department of Health, Office of Drinking Water Quality; Amanda Aretz, Andrew Thorpe, and Carol Gannon, formerly of the U.S. Geological Survey; and Dennis Ventetuolo and Tomas Smieszek, U.S. Geological Survey.

\section{Selected References}

Allen, W.B., 1953, The ground-water resources of Rhode Island, with a section on Surface-water resources, by H.B. Kinnison: Rhode Island Water Resources Board Geological Bulletin 6, 170 p.

Allen, W.B., 1956, Ground-water resources of the East Greenwich quadrangle, Rhode Island: Rhode Island Water Resources Board Geological Bulletin 8, 56 p., 3 pl., scale $1: 24,000$.

Allen, W.B., and Lang, S.M., 1957, Ground-water levels in Rhode Island, 1956: Rhode Island Water Resources Board Hydrologic Bulletin 1, $21 \mathrm{p}$.

Allen, W.B., Johnson, K.E., and Mason, R.A., 1959, Crompton quadrangle, Rhode Island: Rhode Island Water Resources Board Ground-Water Map 3, 1 pl., scale 1:24,000.

Barlow, L.K., 2003, Estimated water use and availability in the lower Blackstone River Basin, northern Rhode Island and south-central Massachusetts, 1995-99: U.S. Geological Survey Water-Investigations Report 03-4190, 85 p.

Barosh, P.J., 1976, Preliminary bedrock geology map of the Oxford quadrangle, Massachusetts, Connecticut, and Rhode Island: U.S. Geological Survey Open-File Report 76-622, 5 p., 1 pl., scale 1:24,000.

Barlow, P.M., and Dickerman, D.C., 2001, Numerical-simulation and conjunctive management models of the HuntAnnaquatucket-Pettaquamscutt stream-aquifer system, Rhode Island: U.S. Geological Survey Professional Paper 1636, 79 p.

Bierschenk, W.H., 1959, Ground-water resources of the Providence quadrangle, Rhode Island: Rhode Island Water Resources Board Geological Bulletin 10, 104 p., 3 pl., scale 1:31,680.

Bierschenk, W.H. and Hahn, G.W., 1959, Hope Valley quadrangle, Rhode Island: Rhode Island Water Resources Board Ground-Water Map 6, 1 pl., scale 1:24,000. 
Breault, R.F., Waldron, M.C., Barlow, L.K., and Dickerman, D.C., 2000, Water-quality conditions and relation to drainage-basin characteristics in the Scituate Reservoir Basin, Rhode Island, 1982-95: U.S. Geological Survey WaterResources Investigations Report 2000-4086, 46 p.

Cervione, M.A., Jr., Richardson, A.R., and Weiss, L.A., 1993, Low-flow characteristics of selected streams in Rhode Island: U.S. Geological Survey Water-Resources Investigations Report 93-4046, 16 p.

Craft, P.A., Horn, M.A., and Medalie, Laura, 1995, Estimated withdrawals and use of freshwater in Rhode Island, 1990: U.S. Geological Survey Water-Resources Investigations Report 93-4150, 1 p.

Crosby, W.O., 1904, Notes on the wells, springs, and general water resources of certain eastern and central States-Rhode Island, in Contributions to the hydrology of eastern United States, 1903: U.S. Geological Survey Water-Supply Paper 102, p. 119-125.

Crosby, W.O., 1905, Massachusetts and Rhode Island, in Underground waters of eastern United States: U.S. Geological Survey Water-Supply Paper 114, p. 68-75.

Cushman, R.V., Allen, R.B., and Pree, H.L., Jr., 1953, Geologic factors affecting the yield of rock wells in southern New England: Journal of the New England Water Works Association, v. 67, no. 2, p. 77-95.

DeSimone, L.A., and Ostiguy, L.J., 1999, A vulnerability assessment of public-supply wells in Rhode Island: WaterResources Investigations Report 99-4160, 153 p.

Dickerman, D.C., 1976, Geohydrologic data for the Chipuxet River ground-water reservoir, Rhode Island: Rhode Island Water Resources Board Information Series Report 2, 86 p.

Dickerman, D.C., 1984, Aquifer tests in the stratified drift, Chipuxet River Basin, Rhode Island: U.S. Geological Survey Water-Resources Investigations Report 83-4231, 39 p.

Dickerman, D.C., and Bell, R.W., 1993, Hydrogeology, water quality, and ground-water development alternatives in the Upper Wood River ground-water reservoir, Rhode Island: U.S. Geological Survey Water-Resources Investigations Report 92-4119, 87 p.

Dickerman, D.C., and Johnston, H.E., 1977, Geohydrologic data for the Beaver-Pasquiset ground-water reservoir, Rhode Island: Rhode Island Water Resources Board Water Information Series Report 3, 128 p.

Dickerman, D.C., Kliever, J.D., Stone, J.R., 1997, Hydrogeology, water quality, and simulation of ground-water-development alternatives in the Usquepaug-Queen ground-water reservoir, southern Rhode Island: U.S. Geological Survey Water-Resources Investigations Report 97-4126, p. 48, 1 pl., scale 1:24,000.

Dickerman, D.C., and Ozbilgin, M.M., 1985, Hydrogeology, water quality, and ground-water development alternatives in the Beaver-Pasquiset ground-water reservoir, Rhode Island: U.S. Geological Survey Water-Resources Investigations Report 85-4190, 104 p.
Dickerman, D.C., and Silva, P.J., 1980, Geohydrologic data for the lower Wood River ground-water reservoir, Rhode Island: Rhode Island Water Resources Board Water Information Series Report 4, 193 p., 1 pl., scale 1:24,000.

Dickerman, D.C., Bell, R.W., Mulvey, K.D., Peterman, E.L., and Russell, J.P., 1989, Geohydrologic data for the upper Wood River ground-water reservoir, Rhode Island: Rhode Island Water Resources Board Water Information Series Report 5, 274 p., scale 1:24,000.

Dickerman, D.C., Trench, E.C.T., and Russell, J.P., 1990, Hydrogeology, water quality and ground-water development alternatives in Lower Wood River ground-water reservoir, Rhode Island: U.S. Geological Survey Water-Resources Investigations Report 89-4031, 109 p.

Dixon, H.R., 1974, Bedrock geologic map of the Thompson quadrangle, Windham County, Connecticut, and Providence County, Rhode Island: U. S. Geological Survey Geologic Quadrangle Map GQ-1165, 1 pl., scale 1:24,000.

Federal Geographic Data Committee, 2002, Federal standards for delineation of hydrologic unit boundaries, FGDC Proposal, version 1.0, March 1, 2002, accessed August 2, 2004 at http://www2.state.id.us/itrmc/committees/igc/ i-plan/AppEWatershedsA.pdf

Feininger, Tomas, 1962, Surficial geology of the Hope Valley quadrangle, Rhode Island: U.S. Geological Survey Geologic Quadrangle Map GQ-166, 1 pl., scale 1:24,000.

Feininger, Tomas, 1965a, Bedrock geologic map of the Voluntown quadrangle, New London County, Connecticut, and Kent and Washington Counties, Rhode Island: U.S. Geological Survey Geologic Quadrangle Map GQ-436, 1 pl., scale 1:24,000.

Feininger, Tomas, 1965b, Surficial geologic map of the Voluntown quadrangle, Connecticut-Rhode Island: U.S. Geological Survey Geologic Quadrangle Map GQ-469, 1 pl., scale 1:24,000.

GolfCourse.com, 2002, Find a course, accessed August 10, 2002 at http://www.golfcourse.com/.

Gonthier, J.B., 1966, Hydrologic data for the South Branch Pawtuxet River Basin, Rhode Island: Rhode Island Water Resources Board Hydrologic Bulletin 6, 35 p., 2 pl., scale $1: 24,000$.

Gonthier, J.B., Johnston, H.E., and Malmberg, G.T., 1974, Availability of ground water in the lower Pawcatuck Basin: U.S. Geological Survey Water-Supply Paper 2033, 40 p.

Hahn, G.W., 1959, Slocum quadrangle, Rhode Island: Rhode Island Water Resources Board Ground-Water Map 2, 1 pl., scale 1:24,000.

Hahn, G.W., 1961, Ground-water resources in the vicinity of Wallum Lake, Rhode Island: Rhode Island Water Resources Board Geological Bulletin 12, 34 p., 4 pl., scale 1:24,000.

Hahn, G.W., and Hansen, A.J., Jr., 1961, Chepachet quadrangle, Rhode Island: Rhode Island Water Resources Board Ground-Water Map 15, 1 pl., scale 1:24,000.

Hahn, G.W., and Wosinski, J.A., 1960, Ground water levels in Rhode Island, 1957: Rhode Island Water Resources Board Hydrologic Bulletin 2, 32 p. 
Hansen, A.J., Jr., 1962a, Clayville quadrangle, Rhode Island: Rhode Island Water Resources Board Ground-Water Map 17, 1 pl., scale 1:24,000.

Hansen, A.J., Jr., 1962b, Rhode Island parts of the Thompson and East Killingly quadrangles: Rhode Island Water Resources Board Ground-Water Map 18, 1 pl., scale $1: 24,000$.

Hansen, A.J., Jr., and Schiner, G.R., 1963, Ground-water levels in Rhode Island, 1958-1962: Rhode Island Water Resources Coordinating Board Hydrologic Bulletin 5, 49 p.

Harwood, D.S., and Goldsmith, Richard, 1971a, Bedrock geologic map of the Oneco quadrangle, Connecticut-Rhode Island: U.S. Geological Survey Geologic Quadrangle Map GQ-930, 1 pl., scale 1:24,000.

Harwood, D.S., and Goldsmith, Richard, 1971b, Surficial geologic map of the Oneco quadrangle, Connecticut-Rhode Island: U.S. Geological Survey Geologic Quadrangle Map GQ-917, 1 pl., scale 1:24,000.

Horn, M.A., 2000, Method for estimating water use and interbasin transfers of freshwater and wastewater in an urbanized basin: U.S. Geological Survey Water-Resources Investigations Report 99-4287, 34 p.

Horn, M.A., 2003, User's manual for the New England wateruse data system (NEWUDS): U. S. Geological Survey OpenFile Report 01-328, 392 p.

Horn, M.A., and Craft, P.A., 1991, Plan for developing a wateruse data program in Rhode Island: U.S. Geological Survey Water-Resources Investigations Report 90-4207, 26 p.

Horn, M.A., Craft, P.A., Bratton, Lisa, 1994, Estimation of water withdrawal and distribution, water use, and wastewater collection and return flow in Cumberland, Rhode Island, 1988: U.S. Geological Survey Water-Resources Investigations Report 93-4023, 54 p.

Jeffords, R.M. and Allen, W.B., 1947, Ground-water conditions in the vicinity of Mashapaug Pond, Providence, Rhode Island: Journal of the New England Water Works Association, v. 62, no. 1, p. 38-61.

Johnson, K.E., 1961, Rhode Island part of the Ashaway quadrangle and some adjacent areas of Connecticut: Rhode Island Water Resources Board Ground-Water Map 16, 1 pl., scale $1: 24,000$.

Johnson, K.E., 1962, Rhode Island parts of the Attleboro, Blackstone, Franklin, Oxford, and Uxbridge quadrangles: Rhode Island Water Resources Board Ground-Water Map 19, 1 pl., scale 1:24,000.

Johnson, K.E., Mason, R.A., and DeLuca, F.A., 1960, Oneco quadrangle, Connecticut-Rhode Island: Rhode Island Water Resources Board Ground-Water Map 10, 1 pl., scale $1: 24,000$.

Johnston, H.E. and Dickerman, D.C., 1974, Availability of ground water in the Branch River basin, Rhode Island: U.S. Geological Survey Water-Resources Investigations Report 74-18, 20 p.
Johnston, H.E. and Dickerman, D.C., 1985, Hydrology, water quality, and ground-water development alternatives in the Chipuxet ground-water reservoir, Rhode Island: U.S. Geological Survey Water-Resources Investigations Report 84-4254, 100 p.

Johnston, H.E., 1988, U.S. Geological Survey ground-water studies in Rhode Island: U.S. Geological Survey Open-File Report 88-139, 1 sheet.

Kliever, J.D., 1995, Hydrologic data for the Usquepaug-Queen Basin, Rhode Island: U.S. Geological Survey Open-File Report 95-305 and State of Rhode Island Water Resources Board Water Information Series Report 6, 68 p., 1 pl., scale 1:24,000.

Kliever, J.D., 1996, Low-flow characteristics of selected streams in northern Rhode Island: U.S. Geological Survey Water-Resources Investigations Report 95-4299, 11 p.

Knox, C.E., and Nordenson, T.J., 1955, Average annual runoff and precipitation in the New England-New York area, U.S. Geological Survey Hydrological Investigations Atlas 7, 5 pls., scale 1:1,000,000.

Korzendorfer, B.A., and Horn, M.A., 1995, Estimated water use in the New England States, 1990: U.S. Geological Survey Water-Resources Investigations Report 94-4252, 21 p.

Lang, S.M., 1961, Appraisal of the ground-water reservoir areas in Rhode Island: Rhode Island Water Resources Board Geological Bulletin 11, 38 p.

Lang, S.M., Bierschenk, W.H., and Allen, W.B., 1960, Hydraulic characteristics of glacial outwash in Rhode Island: Rhode Island Water Resources Board Hydrologic Bulletin 3, 38 p.

Mason, R.A., and Hahn, G.W., 1960, Coventry Center quadrangle, Rhode Island: Rhode Island Water Resources Board Ground-Water Map 8, 1 pl., scale 1:24,000.

Medalie, Laura, 1996, Wastewater collection and return flow in New England, 1990: U.S. Geological Survey WaterResources Investigations Report 95-4144, 79 p.

Melvin, R.L., de Lima, Virginia, and Stone, B.D., 1992, Stratigraphy and hydraulic properties of tills in southern New England: U.S. Geological Survey Open-File Report 91-481, $53 \mathrm{p}$.

Moore, G.E., Jr., 1958, Bedrock geologic map of the Hope Valley quadrangle, Rhode Island: U.S. Geological Survey Geologic Quadrangle Map GQ-105, 1 pl., scale 1:24,000.

Moore, G.E., Jr., 1963, Bedrock geologic map of the Coventry Center quadrangle, Rhode Island: U.S. Geological Survey Bulletin 1158-A, 24 p., 1 pl., scale 1:24,000.

Morrissey, D.J., 1984, National water summary 1983-Rhode Island water issues: U.S. Geological Survey Water-Supply Paper 2250, p. 203-206.

Morrissey, D.J., 1989, Estimation of the recharge area contributing water to a pumped well in a glacial-drift, river-valley aquifer: U.S. Geological Survey Water-Supply Paper 2338, $41 \mathrm{p}$.

National Oceanic and Atmospheric Administration, 2000, Normal monthly precipitation, accessed August 4, 2001, at http://www7.ncdc.noaa.gov/IPS/index.jsp 
National Oceanic and Atmospheric Administration, 2002, Normal daily mean temperature, degrees F, accessed September 5, 2002, at http://www.ncdc.noaa.gov/oa/ climate/online/ccd/meantemp.html

Natural Resources Conservation Service, 2003, Watershed Boundary Dataset, accessed December 18, 2003, at http://www.ncgc.nrcs.usda.gov/products/datasets/watershed/.

Nimiroski, M.T. and Waldron, M.C., 2002, Sources of sodium and chloride in the Scituate Reservoir drainage basin, Rhode Island: U.S. Geological Survey Water-Resources Investigations Report 02-4149, 16 p.

Nimiroski, M.T., and Wild, E.C., 2005, Water use and availability in the Woonasquatucket and Moshassuck River Basins, north-central Rhode Island: U.S. Geological Survey Scientific Investigations Report 2005-5031, 44 p.

Pollock, S.J., 1960, North Scituate quadrangle, Rhode Island: Rhode Island Water Resources Board Ground-Water Map 12, 1 pl., scale 1:24,000.

Power, W.R., Jr., 1957, Surficial geology of the Slocum quadrangle, Rhode Island: U.S. Geological Survey Geologic Quadrangle Map GQ-106, 1 pl., scale 1:24,000.

Power, W.R., Jr., 1959, Bedrock geology of the Slocum quadrangle, Rhode Island: U.S. Geological Survey Geologic Quadrangle Map GQ-114, 1 pl., scale 1:24,000.

Quinn, A.W., 1951, Bedrock geology of the North Scituate quadrangle, Rhode Island: U.S. Geological Survey Geologic Quadrangle Map GQ-13, 1 pl., scale 1:31,680.

Quinn, A.W., 1952, Bedrock geology of the East Greenwich quadrangle, Rhode Island: U.S. Geological Survey Geologic Quadrangle Map GQ-17, 1 pl., scale 1:31,680.

Quinn, A.W., 1959, Bedrock geology of the Providence quadrangle, Rhode Island: U.S. Geological Survey Geologic Quadrangle Map GQ-118, 1 pl., scale 1:24,000.

Quinn, A.W., 1963, Bedrock geologic map of the Crompton quadrangle, Rhode Island: U.S. Geological Survey Bulletin 1158-B, 17 p., 1 pl., scale 1:24,000.

Quinn, A.W., 1967, Bedrock geologic map of the Chepachet quadrangle, Rhode Island: U.S. Geological Survey Bulletin 1241-G, 26 p., 1 pl., scale 1:24,000.

Quinn, A.W., 1963, Bedrock geology of Rhode Island: U.S. Geological Survey Bulletin 1295, 68 p., 1 pl., scale 1:125,000.

Randall, A.D., Bierschenk, W.H., and Hahn, G.W., 1960, Voluntown quadrangle, Connecticut-Rhode Island: Rhode Island Water Resources Board Ground-Water Map 13, 1 pl., scale 1:24,000.

Rhode Island Department of Environmental Management, 2001, Freshwater wetlands act, accessed 2001, at http:// www.state.ri.us/dem/pubs/regs/regs/water/wetlnd98.pdf/.

Rhode Island Department of Environmental Management, Division of Agriculture, 2006, Overview, accessed May 20, 2006 at http://www.dem.ri.gov/programs/bnatres/agricult/index.htm
Rhode Island Economic Development Corporation, 1999, High tech industries in Rhode Island, accessed on October 20, 2000 at http://www.riedc.com/pdfpubs/99_High_Tech_Catal.pdf

Rhode Island Economic Development Corporation, 2000a, Export/import directory, accessed on October 20, 2000 at http://www.riedc.com/pdfpubs/riexporters.pdf

Rhode Island Economic Development Corporation, 2000b, Major employers in Rhode Island, accessed on October 20, 2000 at http://www.riedc.com/pdfpubs/Employers.pdf

Rhode Island Economic Development Corporation, 2001, City and town population estimates, accessed December 19, 2001, at http://www.riedc.com/mcds/rimcdrame.html

Rhode Island Geographic Information System, 1988, Glacial geology of Rhode Island from 1965 USGS classification and mapping, accessed April 2, 2002, at http:// www.edc.uri.edu/rigis-spf/statewide/state.html\#geology

Rhode Island Geographic Information System, 1991, U.S. Census 1990 population and housing information, accessed April 2, 2002, at http://www.edc.uri.edu/rigis-spf/statewide/state.html\#demographic

Rhode Island Geographic Information System, 1995a, 1995 land use coverage, accessed April 2, 2002, at http:// www.edc.uri.edu/rigis-spf/statewide/state.html\#landuse

Rhode Island Geographic Information System, 1995b, Water supply districts, accessed April 2, 2002, at http:// www.edc.uri.edu/rigis-spf/statewide/state.html\#utilities

Rhode Island Geographic Information System, 1997a, Community well coverage, accessed April 2, 2002, at http://www.edc.uri.edu/rigis-spf/statewide/state.html\#hydrography

Rhode Island Geographic Information System, 1997b, Noncommunity well coverage, accessed April 2, 2002, at http://www.edc.uri.edu/rigis-spf/statewide/ state.html\#hydrography

Rhode Island Geographic Information System, 1999, Rhode Island point discharge elimination system point locations, accessed April, 2002, at URL http://www.edc.uri.edu/rigisspf/statewide/state.html\#hazmat

Rhode Island Statewide Planning, 2001, Population of Rhode Island by State, county, and city and town Rhode Island, 1990 \& 2000, accessed September 30, 2001, at http://www.planning.ri.gov/census/pdf\%20files/miscpdf/popcity.pdf

Rhode Island Water Resources Board, 2003, Our mission, accessed August 3, 2003, at http://www.wrb.state.ri.us/ mission/index.html

Richmond, G.M., 1952, Bedrock geology of the Georgiaville quadrangle, Rhode Island: U.S. Geological Survey Geologic Quadrangle Map GQ-16, 1 pl., scale 1:31,680.

Richmond, G.M., 1953, Surficial geology of the Georgiaville quadrangle, Rhode Island: U.S. Geological Survey Geologic Quadrangle Map GQ-22, 1 pl., scale 1:31,680.

Richmond G.M. and Allen, W.B., 1951, The geology and ground-water resources of the Georgiaville quadrangle, Rhode Island: Rhode Island Water Resources Board Geological Bulletin 4, 75 p., 3 pl., scale 1:31,680. 
Ries, K.G., III, 1990, Estimating surface-water runoff to Narragansett Bay, Rhode Island and Massachusetts: U.S. Geological Survey Water-Resources Investigations Report 89-4164, 44 p., 1 pl., scale 1:125,000.

Robinson, C.S., 1961, Surficial geology of the North Scituate quadrangle, Rhode Island: U.S. Geological Survey Geologic Quadrangle Map GQ-22, 1 pl., scale 1:24,000.

Roberts, C.M., and Brashears, M.L., Jr., 1945, Progress report on the ground-water resources of Providence, Rhode Island: Rhode Island Water Resources Board Geological Bulletin 1, 35 p., 2 pl., scale 1:31,680.

Roberts, C.M., and Halberg, H.N., 1945, Well and test hole records for Providence, Rhode Island: Rhode Island Water Resources Board Geological Bulletin 2, 52 p., 2 pl., scale $1: 31,680$.

Ruddy, B.C., and Hitt, K.J., 1990, Summary of selected characteristics of large reservoirs in the United States and Puerto Rico, 1988: U.S. Geological Survey Open-File Report 90-163, $265 \mathrm{p}$.

Rutledge, A.T., 1993, Computer programs for describing the recession of ground-water discharge and for estimating mean ground-water recharge and discharge from streamflow records: U.S. Geological Survey Water-Resources Investigations Report 93-4121, 45 p.

Rutledge, A.T., 1998, Computer programs for describing the recession of ground-water discharge and for estimating mean ground-water recharge and discharge from streamflow records-update: U.S. Geological Survey Water-Resources Investigations Report 98-4148, 43 p.

Simcox, A.C., 1992, Water resources of Massachusetts: U.S. Geological Survey Water-Resources Investigations Report 90-4144, 94 p.

Smith, J.H., 1955, Surficial geology of the East Greenwich quadrangle, Rhode Island: U.S. Geological Survey Geologic Quadrangle Map GQ-62, 1 pl., scale 1:31,680.

Smith, J.H., 1956a, Surficial geology of the Crompton quadrangle, Rhode Island: U.S. Geological Survey Geologic Quadrangle Map GQ-94, 1 pl., scale 1:31,680.

Smith, J.H., 1956b, Surficial geology of the Providence quadrangle, Rhode Island: U.S. Geological Survey Geologic Quadrangle Map GQ-84, 1 pl., scale 1:31,680.

Socolow, R.S., Whitley, J.S., Murino, Domenic, and Ramsbey, L.R., 2001, Water resources data, Massachusetts and Rhode Island water year 2000: U.S. Geological Survey Water-Data Report MA-RI-00-1, 459 p.

Soil and Conservation Service, 1993, Estimation of water use by agricultural enterprises during calendar year 1988: U. S. Department of Agriculture Cooperative River Basin Study \#4347, 30 p.

Solley, W.B., Pierce, R.R., Perlman, H.A., 1998, Estimated water use in the United States in 1995: U.S. Geological Survey Circular 1200, $71 \mathrm{p}$.

Tessler, Steven, 2002, Data model and relational database design for the New England water-use data system (NEWUDS): U.S. Geological Survey Open-File Report 01-359, $164 \mathrm{p}$.
Thomas, C.E., Jr., Randall, A.D., and Thomas, M.P., 1966, Hydrogeologic data in the Quinebaug River Basin, Connecticut: Connecticut Water Resources Bulletin 9, 84 p.

Trench, E.C.T., 1991, Ground-water resources of Rhode Island: U.S. Geological Survey Open-File Report 91-199, 169 p.

Trench, E.C.T., 1995, Sources of geologic and hydrologic information pertinent to ground-water resources in Rhode Island: U.S. Geological Survey Open-File Report 93-464, $98 \mathrm{p}$.

U.S. Department of Agriculture, 1997a, 1997 Census of Agriculture Volume 1, Part 7, Chapter 2, Connecticut countylevel data, accessed May 5, 1999, at http://www.nass.usda.gov/census/census97/volume1/ ct-7/toc297.htm

U.S. Department of Agriculture, 1997b, 1997 Census of Agriculture Volume 1, Part 39, Chapter 2, Rhode Island countylevel data, accessed May 5, 1999, at http://www.nass.usda.gov/census/census97/volume1/ ri-39/toc297.htm

U.S. Fish and Wildlife Service, 1981, Interim regional policy for New England stream flow recommendations: Newton Corner, Mass., U.S. Fish and Wildlife Service, 3 p.

U.S. Geological Survey, 2003, National Mapping Program standards, accessed August 6, 2003, at http://rmmcweb.cr.usgs.gov/public/nmpstds/nhdstds.html.

U.S. Geological Survey, 2004, The water cycle, accessed January 28, 2004, at http://ga.water.usgs.gov/ edu/watercycle.html

U. S. Government Printing Office, Code of Federal Regulations, 1996, Title 40-Protection of Environment, Part 141-National Primary Drinking Water Regulations, section 2, accessed online June 20, 2005, at http://www. gpoaccess.gov/cfr/index.html

Weston, R.F., Inc., 1990, Scituate Reservoir Complex safe yield analysis, $59 \mathrm{p}$.

Wild, E.C, and Nimiroski, M.T., 2004, Estimated water use and availability in the Pawcatuck Basin, southern Rhode Island and southeastern Connecticut, 1995-99: U.S. Geological Survey Scientific Investigations Report 2004-5020, 80 p.

Wild, E.C., and Nimiroski, M.T., 2005, Estimated water use and availability in the South Coastal Drainage Basin, southern Rhode Island, 1995-99: U.S. Geological Survey Scientific Investigations Report 2004-5288, 46 p.

WorldGolf.com, 2002, Golf courses in Rhode Island, accessed August 10, 2002 at http://www.worldgolf.com/courses/unitedstates/rigcs.html

Zarriello, P.J., and Socolow, R.S., 2003, The U.S. Geological Survey streamflow and observation-well network in Massachusetts and Rhode Island: U.S. Geological Survey OpenFile Report 03-277, 120 p. 


\section{Glossary}

7-day, 10-year low flow (7010) The discharge at the 10-year recurrence interval taken from a frequency curve of annual values of the lowest mean discharge for 7 consecutive days (the 7-day low flow).

Aquatic Base Flow (ABF) As established by the U.S. Fish and Wildlife Service, median flow during the month of August considered adequate to protect indigenous aquatic fauna throughout the year. It can be calculated as long as there are USGS stream-gaging data for at least 25 years of unregulated flow, and the drainage area at the stream-gaging station is at least 50 square miles (U.S. Fish and Wildlife, 1981).

Base flow Streamflow from ground-water discharge.

Commercial water use Water used for transportation; wholesale trade; retail trade; finance, insurance, and real estate; services; and public administration (the two-digit Standard Industrial Classification codes are in the range 40-97). The water can be from public or self-supply.

Consumptive use Water that is removed from the environment through evaporation, transpiration, production, or consumed by humans or livestock.

Conveyance Movement of water from one point to another, for example, water withdrawals, water distributions, and wastewater collection.

Distribution The conveyance of water from a point of withdrawal or purification system to a user or other water customer.

Domestic water use Water used for household purposes, such as drinking, food preparation, bathing, washing, clothes and dishes, flushing toilets, and watering lawns and gardens. Households include single and multifamily dwellings. Also called residential water use. The water may be obtained from a public water supply or may be self-supplied.

Industrial water use Water used for food; tobacco; textile mill products; apparel; lumber and wood; furniture; paper; printing; chemicals; petroleum; rubber; leather; stone, clay, glass, and concrete; primary metal; fabricated metal;

machinery; electrical equipment; transportation equipment; instruments; and jewelry, precious metals; for which the twodigit Standard Industrial Classification code range is 20-39. The water may be obtained from a public water supply or may be self-supplied.

Interbasin transfers Conveyance of water across a drainage or river-basin divide.

Interconnections Links between public-supply districts to convey water. These connections can be for wholesale distributions or water-supply backups.

Irrigation water use The application of water to lands to assist in the growth of crops or pasture, including plants in greenhouses. Irrigation water use may also include application of water to maintain vegetative growth on recreational lands such as parks and golf courses and to provide frost and freeze protection of crops.

Major water supplier A public or private system that withdraws and distributes water to customers or other suppliers for use.

Major user In Rhode Island, a customer that uses more than three million gallons of water per year.

Minor Civil Division (MCD) A term used by the U.S. Census Bureau, generally equivalent to a city or town.

Minor public water suppliers Water withdrawn to supply a site-specific public population, for example nursing homes, condominium complexes, and mobile home parks.

Nonaccount water use The difference between the metered (or reported) supply and the metered (or reported) use for a specific period of time, which includes water used for fire fighting. It comprises authorized and unauthorized water uses.

Outfall The outlet or structure through which effluent is finally discharged into the environment.

Per capita water use The average volume of water used per person during a standard time period, generally per day.

PART A computer program developed by A.T. Rutledge (1993 and 1998) to determine the mean rate of ground-water discharge.

Public wastewater system Wastewater collected from users or groups of users, conveyed to a wastewater-treatment plant, and then released as return flow into the hydrologic environment or sent back to users as reclaimed wastewater.

Public water system Water withdrawn by public and private water systems, and then delivered to users or groups of users. Public water systems provide water for a variety of uses, such as domestic, commercial, industrial, agricultural, and public water use.

Public water use Water supplied from a public water system and used for fire fighting, street washing, and municipal parks and swimming pools.

Public-disposed water Wastewater return flow from public and private wastewater-collection systems.

Public-supply water Water distributed to domestic, industrial, commercial, agricultural or other customers by a public or private water-supply system.

Return flow Water that is returned to surface or ground water after use or wastewater treatment, and thus becomes available for reuse. Return flow can go directly to surface water, directly to ground water through an injection well or infiltration bed, or indirectly to ground water through a septic system.

Self-disposed water Water returned to the ground (septic systems) by a user or group of users that are not on a wastewater-collection system.

Self-supply water Water withdrawn from a ground- or surface-water source by a user and not obtained from a public or private water-supply system. 
Standard Industrial Classification (SIC) code Four-digit codes established by the U.S. Office of Management and Budget and used in the classification of establishments by type of activity in which they are engaged. The IWR-MAIN

coefficients for industrial and commercial water use are based on the first two digits.

Surface-water return flow Effluent that flows from a discharge pipe to a river or lake.

Wastewater Water that carries wastes from domestic, industrial, and commercial consumers; a mixture of water and dissolved or suspended solids.

Wastewater treatment The processing of wastewater for the removal or reduction of contained solids or other undesirable constituents.

Wastewater-treatment return flow Water returned to the hydrologic system by wastewater-treatment facilities. Also referred to as effluent water.
Water purification The processes that withdrawn water may undergo prior to use, including chlorination, fluoridation, and filtration.

Water supply All of the processes that are involved in obtaining water for the user before use. Includes withdrawal, water treatment, and other distribution.

Water use (1) In a restrictive sense, the term refers to water that is actually used for a specific purpose, such as for domestic use, irrigation, or industrial processing. (2) More broadly, water use pertains to human interaction with and impact on the hydrologic cycle, and includes elements such as water withdrawal, distribution, consumptive use, wastewater collection, and return flow.

Withdrawal The removal of surface water or ground water from the natural hydrologic system for uses such as public water supply, industry, commerce, domestic use, irrigation, livestock, and thermoelectric power generation. 